DOE/NASA CONTRACTOR

DOE/NASA CR- 161550 REPORT

\title{
SOLAR HEATING SYSTEM AT SECURITY STATE BANK, STARKVILLE, MISSISSIPPI - FINAL REPORT
}

Prepared from documents furnished by

Security State Bank

P. O. Box Drawer 1127

Starkville, Mississippi 39759

Under DOE Contract EM-78-F-01-5198

Monitored by

National Aeronautics and Space Administration

George C. Marshall Space Flight Center, Alabama 35812

For the U. S. Department of Energy

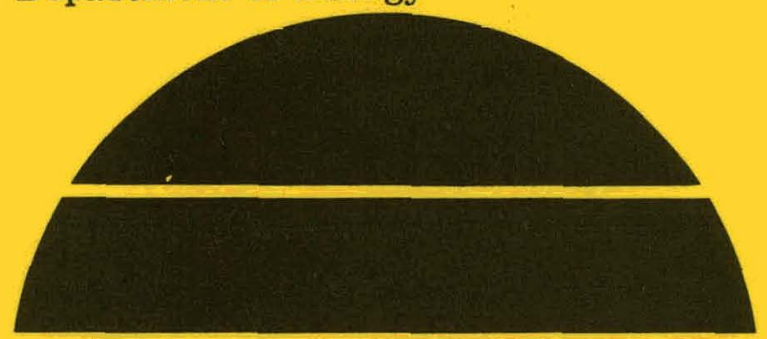

\section{U.S. Department of Energy}

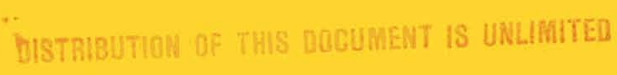

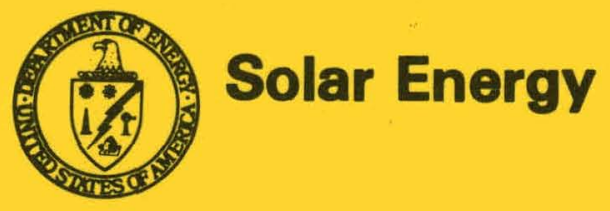




\section{DISCLAIMER}

This report was prepared as an account of work sponsored by an agency of the United States Government. Neither the United States Government nor any agency Thereof, nor any of their employees, makes any warranty, express or implied, or assumes any legal liability or responsibility for the accuracy, completeness, or usefulness of any information, apparatus, product, or process disclosed, or represents that its use would not infringe privately owned rights. Reference herein to any specific commercial product, process, or service by trade name, trademark, manufacturer, or otherwise does not necessarily constitute or imply its endorsement, recommendation, or favoring by the United States Government or any agency thereof. The views and opinions of authors expressed herein do not necessarily state or reflect those of the United States Government or any agency thereof. 


\section{DISCLAIMER}

Portions of this document may be illegible in electronic image products. Images are produced from the best available original document. 
This report was prepared to document work sponsored by the United States Government. Neither the United States nor 1ts agents the United States Department of Energy, the United States National Aeronaut1cs and Space Adminlstration, nor any federal employees, nor any of their contractors, subcontractors or their employees, make any warranty, express or implied, or assume any legal liability or responsibllity for the accuracy, completeness, or usefulness of any information, apparatus, product or process disclosed, or represent that its use would not Infringe privately owned rights. 


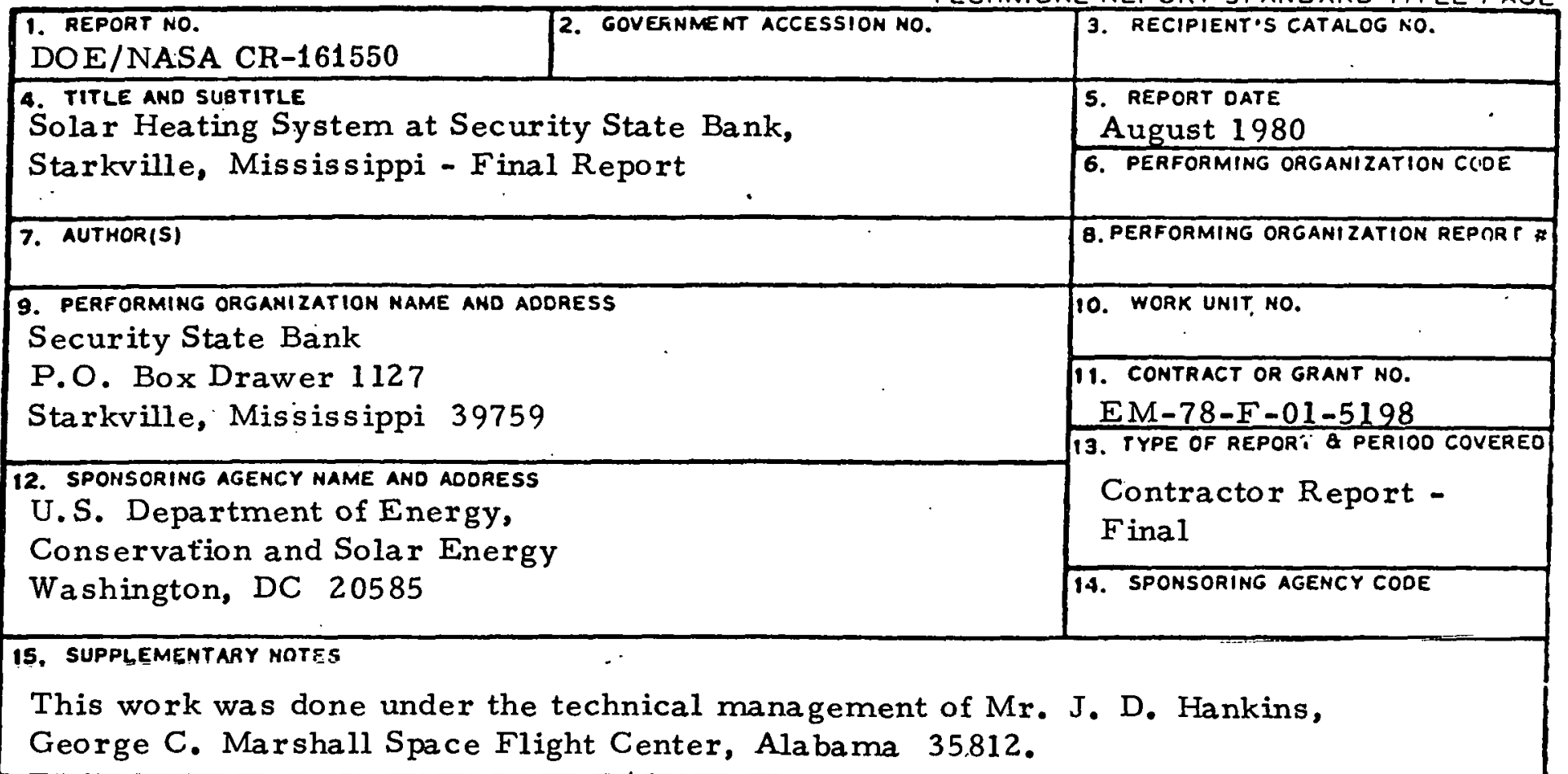

\section{6. aBSTRACT}

This document provides information on the Solar Energy Heating System (airtype) installed at the branch bank building, northwest corner of Highway 12 and Spring Street, Starkville, Mississippi. This installation was completed in June, 1979. The 312 square feet of Solaron flat plate air collectors provide for 788 square feet of space heating, an estimated 55 percent of the heating load. Solar heated air is distributed to the 96 cubic foot oteel cylinder, which contains two inch diameter rocks. An air handler unit moves the air over the collector and into the steel cylinder. Four motorized dampers and two gravity dampers are also part of the system. A Solaron controller which has sensors located at the collectors, rock storage, and at the return air, automatically controls the sys tem. Auxiliary heating energy is provided by electric resistance duct heaters. This project is part of the U.S. Department of Energy's Solar Demonstration Program with the government sharing $\$ 14,201$ of the $\$ 17,498$ solar energy system installation cost. This system was acceptance tested February, 1980, and the demonstration period ends in 1985.

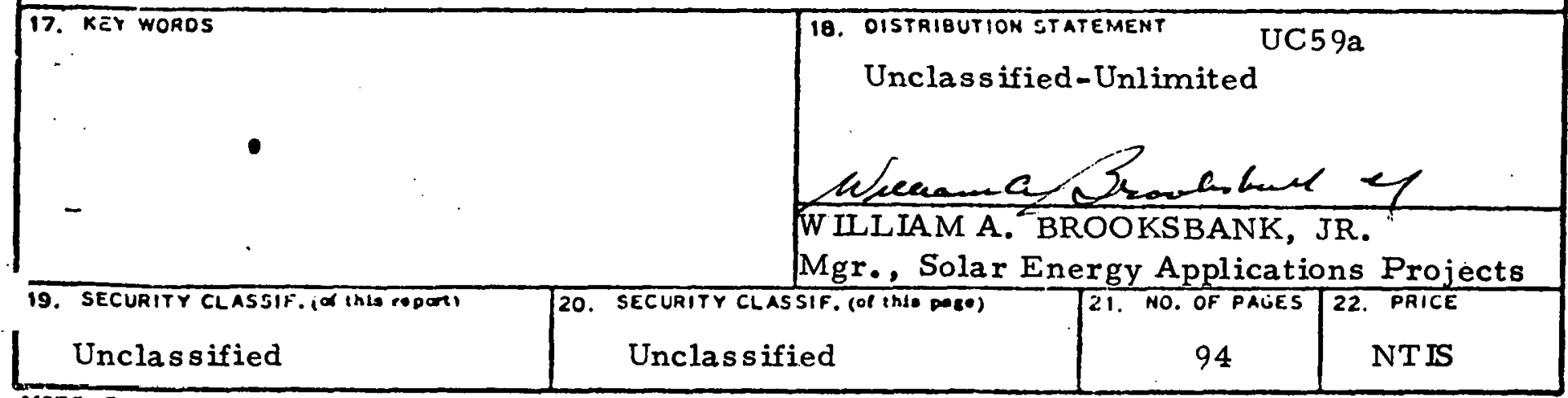


THIS PAGE

\section{WAS INTENTIONALLY LEFT BLANK}


$\underline{\text { Page }}$

SOLAR SYSTEM DESCRIPTION...................... I

KEY WORK ABSTRACT....................... 2

INTRODUCT ION................................ 2

DESIGN PHILOSOPHY......................... 3

OPERATION OF THE SYSTEM. .................... 3

PROBLEMS ENCOUNTERED AND SOLUT IONS............. 4

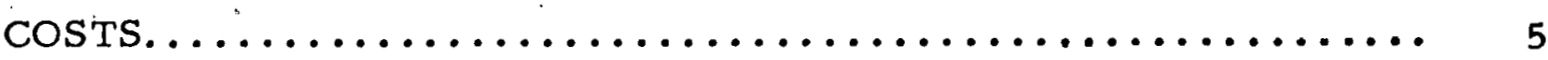

ACCEPTANCE TEST RESULTS....................... 6

COLLECTOR TECHNICAL DATA...................... 8

COLLECTOR INSTALLATION MANUAL.................. 13

AIR HANDLER INSTALLATION MANUAL................. 30

HEAT STORAGE INSTALLATION MANUAL............... 44

DESCRIPTION. . . . . . . . . . . . .

GENERAL NOTES........................... 50

HEAT STORAGE UNIT AND ROCK SIZING............. 52

HEAT STORAGE UNIT - CONCRETE CONSTRUCT ION......... 54

HEAT STORAGE UNIT - WOOD CONSTRUCT ION........... 56

HEAT STORAGE UNIT - ATTACHMENT DETALL.......... 59

OPERATIONAL AIR HANDLER AND DUCT LOCATIONS........ 60

METAL LATH SAMPLE........................... 61

BOND BEAM BLOCK AND TRANSITE DUCT DETAILS......... 62 
TABLE OF CONTENTS (Continued)

$\underline{\text { Page }}$

ROCK AND SIZING METHOD. ..................... 63

HEAT STORAGE UNIT CONSTRUCTION CHECKLIST......... 64

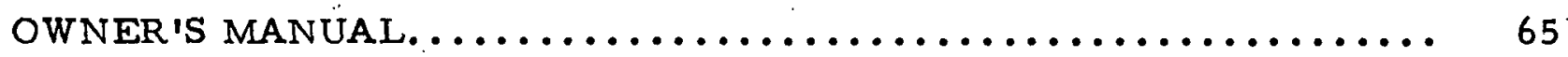

A DESCRIPT ION OF YOUR SOLARON SYSTEM........... 68

OVER VIEW OF SYSTEM. .................... 68

GENERAL SYSTEM DESCR IPT ION................. 69

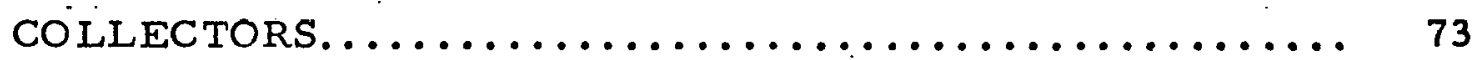

HEAT STORAGE......................... 74

SOLARON AIR HANDLING UNIT................ 76

GRAVITY-OPERATED DAMPERS............... 76

DOMESTIC WATER PREHEATER................ 76

SYS'ILIM CONTROLS......................... 77

AUXILIARY HEATING SYSTEM. ................ 77

HOW TO OPERATE YOUR SOLARON SYSTEM............ 81

ROUTINE MAINTENANCE....................... 83

STEPS TO FOLLOW TO OBTAIN MAXIMUM PERFORMANCE

FROM YOUR SOLARON SYSTEM,................... 84

IF YOUR SOLARON SYSTEM DOES NOT WORK........... 86

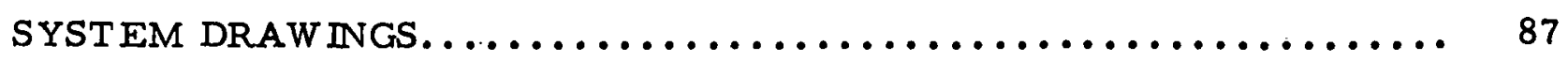


SOLAR SYSTEM DESCRIPTION 
Security. State Bank

Starkville, Mississippi

Alfred M. Alperin

Key Work Abstract

\author{
Application \\ System Type \\ Collector Types \\ Collector Manufacturer \\ Collector Area \\ Storage Capacity \\ Building Load \\ BTU's Produced \\ Building Owner \\ Architect
}

Contractor

\author{
Solar heating \\ Active hot air \\ Flat Plate air \\ Solaron Corporation \\ 312 square feet \\ 96.2 cubic feet \\ $46.49 \times 10^{6} \mathrm{BTU} /$ year without credit \\ for any internal heating credits \\ $25.56 \times 10^{6} \mathrm{BTU} /$ year \\ Security State Bank \\ Starkville, Mississippi \\ Wakeman \& Martin, AIA \\ (a) Thomas \& West \\ Consulting Engineer \\ (b) Designer-Alfred M. Alperin \\ Lowell Oswalt \\ General Contractor. \\ Metts \& Parrish \\ Mechanical Contractor
}

\section{Introduction}

This new building is a drive-in branch of the main office located on a corner lot fronting Highway 12, near the Mississippl state untverslty main campus. It is designed as a modern structure with the roof supporting the solar collectors facing approximately $4^{\circ}$ southeast from due south.

The structure is on a concrete slab with heated space of 788 squarc feet.

Perimeter walls are of Dryyit siding, 1/2" gypsum board sheathing, 4" fiberglass insulation, and 5/8" gypsum board. The roof is metal with $5 / 8$ " wood deck, 9" batt insulation and 5/8" gypsum board. Glass is 5/8" double bronze.

All are designed to minimize heat loss and heat gain.

The mechanical room is on an upper level walled in from the unconditioned space. This space is insulated to minimize sound and heat transfer between the unconditioned and conditioned spaces.

Inrluded in the mechanical system is a Carrier packaged air cooled cooling unit, located in the mechanical room with condenser inlet and outlet air ducted to the unit. In the ductwork distributing conditioned air to the space is a $10 \mathrm{~kW}$, two stage electric resistance heater for backup heat. 


\section{Design Philosophy}

Heating systems in this area are usually hot air, distributed via a ducted system with cooling. Most of the installing mechanics are trained in sheet metal installations, therefore, a hot air solar system seemed to be a natural.

Flat plate air collectors were chosen and most particularly Solaron collectors were chosen by the designer with the Architects' permission for the following reasons:

(a). The designer had been trained at Solaron.

(b) The designer believes the end user is best served by solar air systems with a quality collector, as the problem of maintenance, deterioration, freeziny and stagnation are minimized.

(c) In the opinion of the designer, equal, or more BTU's are delivered to the space by Solaron air systems, as compared to liquid systems.

(d) As there was no need for high temperature, there was no consideration of concentrating or tracking collectors.

A unique feature of this system is the rock storage vessel. This is a steel container, exterior insulated and plastered, which runs from floor to ceiling in the lobby of the bank. In this container is the steel roof supporting column from which the roof supporting trusses are cantilevered. The container will have approximately $9^{\prime} \times 2^{\prime \prime}$ of $2^{\prime \prime}$ screened, washed river rock, which is 2 feet deeper than is normally recommended. This was necessary as the cylinder is only $42^{\prime \prime}$ in diameter. In order to get sufficient storage the extra depth was necessary. In order to keep the air flow resistance at a minimum, the rock size was increased from $3 / 4-11 / 2^{\prime \prime}$ to $2^{\prime \prime}$.

Solar hot water was not included. The bank uses so little hot water, it was not considered feasible.

\section{Operation of The System}

The Solaron system has a special air handling unit to move air over the collector and into the rock storage, with connections to the conventional cooling and air duct distribution system. The motor has class $B$ insulation to prevent deterioration as hot air passes over it. The heat of this motor is added to the heat delivered to the system.

Four motorized, low leakage dampers and two gravity fabric dampers are also part of the system.

The system is designed to be automatically controlled by the Solaron provided controller with three thermistors - one located in the collectors, one in the rock box top plenum, and one in the return air. 
Modes of operation are:

(a) Heating from collectors

(b) Heating from rock storage

(c) Storing heat

(d) Conventional heating (Backup heat)

(3) Conventional cooling

If solar heat: isn't sufficient to maintain space temperature, backup heat can come into operation in conjunction with modes (a) and (b), thereby, taking advantage of any solar BTU's available for the space.

A two stage heating space thermostat controls the room temperature. Backup heat can only be energized by the thermostat's second stage. A time clock provides night set-back control.

The building construction was completed about February 1979, and the solar system was in operation several months of early 1979 and the full winter of 1979 and 1980 .

Embedded in the rock storage system is $33 / 4 "$ conduit with the bottom 2 feet perforated with a series of 1/4" drilled holes. These are located so the bottom of conduit; is at the bottom of the rocks, in the middle and in the top layer of rocks, so future thermistors or temperature probes can be located to sense rock storage temperature.

Problems Encountered and Solutions

A. At the design review with DOE representatives, after much discussion as to how to keep any heat gain that might penetrate the back side of the collectors and be detrimental to the cooling operation, it was decided that a thermostatically controlled exhaust fan will be installed to operate when the mechanical room reaches $95^{\circ} \mathrm{F}$ and the outside temperature is above $70^{\circ} \mathrm{F}$. This proved to be a correct judgement, as the attic would have been extremely warm.

B. Prior to collector installation, a traininy session was held with the installers at their shop, so the installation of the collectors went smoothly.

c. The proper rocks, both in sizing and cleanliness, were not as easy to obtain as we had suspected. This was probably due to the supplier not realizing the need for proper screening and that sand and trash could not be tolerated. Three different loads of rocks were delivered before they were accepted.

D. The loss of two damper motors during this past year of operation indicates that this is a weakness that Solaron needs to investigate and determine if this loss rate is universal. They have been advised of this loss and have replaced the motors to the contractor under warranty.

E. One of the thermistors, the collector temperature sensor, has been replaced. 
F. The need for a better mechanical check of pulleys, bearing brackets. belts, damper linkages seems in order, as some of these have had to be tightened after operation began.

\section{Costs}

Prior to submission of the application to DOE, a substantial set of plans of the solar system was developed and priced accurately by Metts \& Parrish.

After the award, the plans were slightly modified and bid. The final price was substantially the same. The total cost, including architectual and engineering fees and the specially designed storage box was $17,497.53$ 
ACCEPTANCE TEST RESULTS 
S.O.L.A.R. $1900.00 .004 \mathrm{~W}$

Replaces $1900.00 .003 \mathrm{~W}$

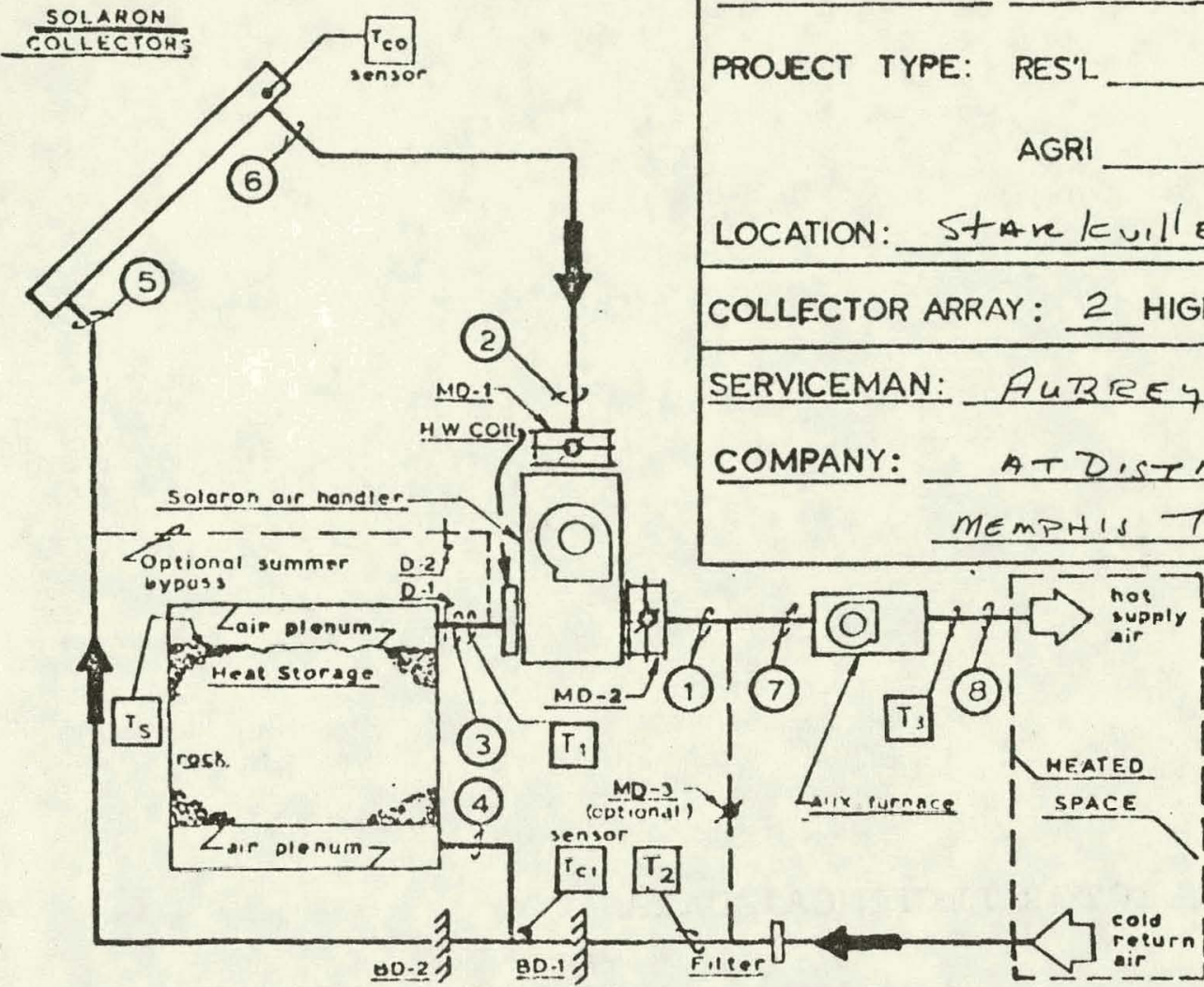

BD.-13

PROJECT NAME: SECURITY STATE BANLPATE: COMM'L OTHER:

$m \$$

$\times 8$ WIDE $=3 / 2$ SQ.FT.

SOLAR HEATING FLOW SCHEMATIC

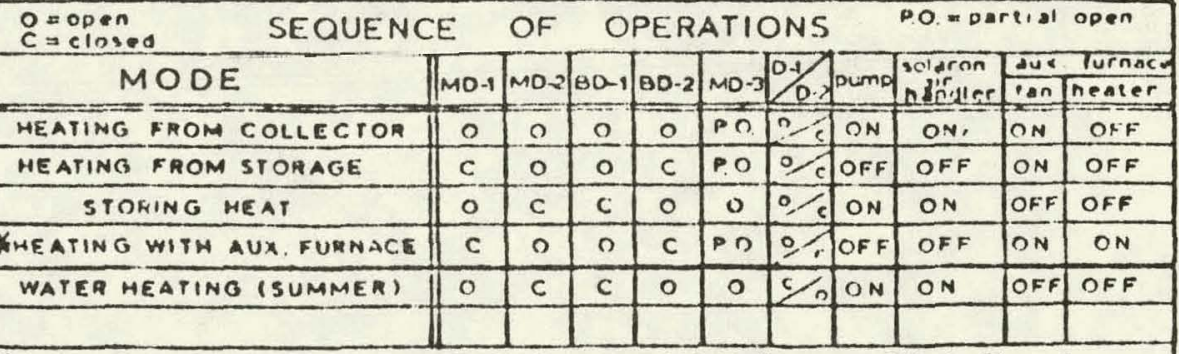
* For Heal Pump Systams: MD-2 Closed, MD-3 Open, BD-1 Closed

$$
T_{3}=\frac{T_{1}\left(C F M_{\text {sol }}\right)+T_{2}\left(C F M_{a u x}-C F M_{\text {sol }}\right)}{C F M_{a u x}}
$$$$
\text { D HuGHes }
$$
PHONE: $(901) 278-7211$

\begin{tabular}{|c|c|c|}
\hline & \multicolumn{2}{|c|}{ AIR HANDLER } \\
\hline & SOLAR & 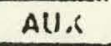 \\
\hline Desion CFM & 624 & 2000 \\
\hline Design Ext SP & 0.92 & .45 \\
\hline Fon RPM & 1160 & 1200 \\
\hline & $1 / 2$ & $1 \frac{1}{2}$ \\
\hline Mofor RPM & 1725 & 3450 \\
\hline Volt & 115 & 231 \\
\hline Phose & 1 & 1 \\
\hline FLA & 6.8 & 3.6 \\
\hline & 1.25 & 1.25 \\
\hline SFA & 8.5 & 4.5 \\
\hline Insul. Class & $" B "$ & $" B$ " \\
\hline Motor $\mathrm{MPO}$ & GE & AOS \\
\hline Model No. & MToos & \\
\hline$T_{1}=$ & $=130^{\circ} \mathrm{F}$ & \\
\hline $\mathrm{T}_{2}=$ & $=68^{\circ} \mathrm{F}$ & \\
\hline$T_{3}=$ & $=117^{\circ} \mathrm{F}$ & \\
\hline
\end{tabular}

TEMPERATURE \& STATIC PRESSURE MEASUREMENTS

\begin{tabular}{|c|c|c|c|c|c|c|c|c|c|c|c|}
\hline \multicolumn{2}{|c|}{ STORING } & \multicolumn{2}{|c|}{ HEAT! } & \multicolumn{4}{|c|}{$\begin{array}{l}\text { HEATING FROM } \\
\text { STORAGE }\end{array}$} & \multicolumn{4}{|c|}{$\begin{array}{l}\text { HEATING FROM, Motor Amp } \\
\text { COLLECTOR }\end{array}$} \\
\hline POINT & ${ }^{\circ} \mathrm{F}$ & \begin{tabular}{|c|} 
STAATIC \\
PRESSUREE
\end{tabular} & Sif. & POINT & ${ }^{\circ} F$ & \begin{tabular}{|c|} 
STATIC \\
PRESSURE \\
\end{tabular} & Siff. & POINT & ${ }^{\circ} \mathrm{F}$ & $\begin{array}{c}\text { STAYIC } \\
\text { PRESSURE } \\
\end{array}$ & $\begin{array}{l}\text { S.P. } \\
\text { DifF. }\end{array}$ \\
\hline 1 & & $0,00^{\prime \prime}$ & & 1 & - & $-0.29^{\prime \prime}$ & & 1 & 142 & $-1.10^{\prime \prime}$ & .70 \\
\hline 2 & 148 & -.21 & & 2 & - & $0.00^{11}$ & & 2 & 144 & $-0.40^{\prime \prime}$ & \\
\hline 3 & 142 & -.41 & & 3 & 130 & -.29 & 25 & 3 & 70 & -0.10 & .02 \\
\hline 4 & 77 & $+.15^{\prime \prime}$ & & 4 & 68 & -.04 & & 4 & 68 & -0.08 & \\
\hline 5 & 83 & & & 5 & - & 0.00 & & 5 & 68 & -0.15 & \\
\hline ? & 150 & & & 6 & - & 0.00 & .0 & 6 & 144 & -0.40 & \\
\hline 7 & & & & 7 & - & $\cdots 0.29$ & & 7 & 117 & -0.30 & \\
\hline 8 & & & & 8 & 130 & +0.41 & 0.60 & 8 & 119 & +0.20 & 3 \\
\hline
\end{tabular}


COLLECTOR TECHNICAL DATA

8 


\section{TECHNICAL DATA}

\section{Series 2000}

\section{Air Type Solar Collector}

\section{PATENTS PENDING}

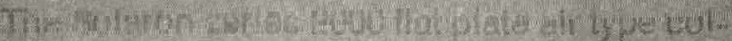
lestw reposgnts the most acvahood tech.

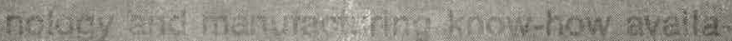

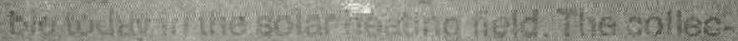

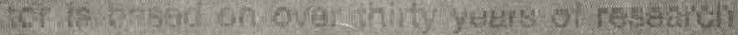
and bifuting and thas proven highly efficiont. rutable aid maintenance tree.

The calloctore are completein tactory preessenbls 10 mintmize field installation time

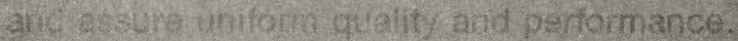

The powhatio pork and manifold sysiom

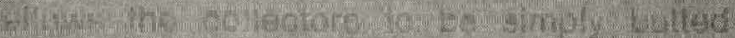

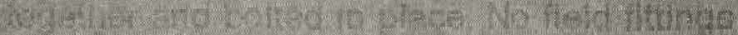

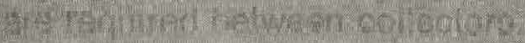

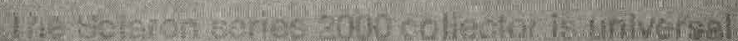
in eppheation. Sub tantiat eriergy sa hige fan

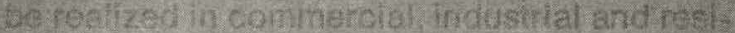
clartai applicatiors subh as

6. WhKEUP ANO FOROED AIR HEATING

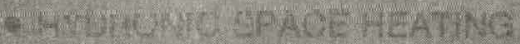

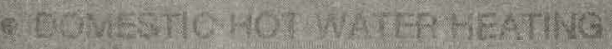

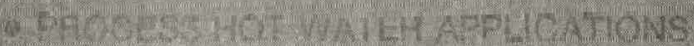

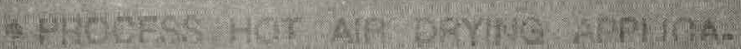

$$
\text { Dones: }
$$

The soliton bystem can be used where ab-

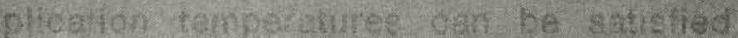

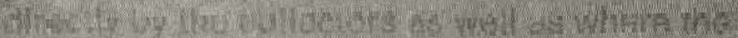

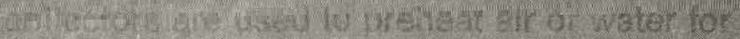

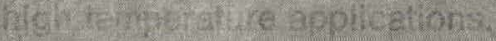

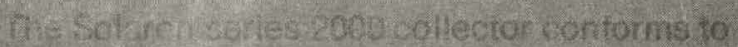

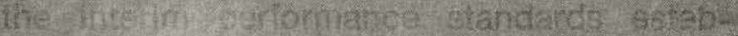

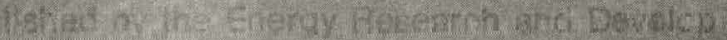

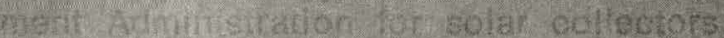
these standerath Inotude:

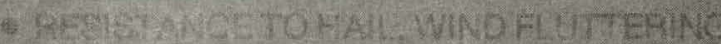

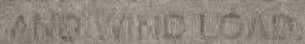

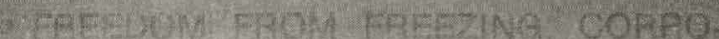

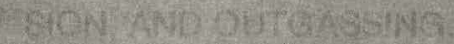

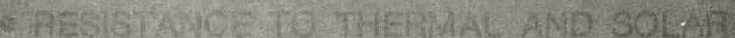
ERERASATON

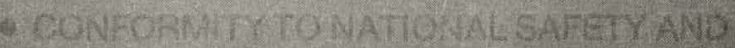
mes $\sin 3 \mathrm{~s}$

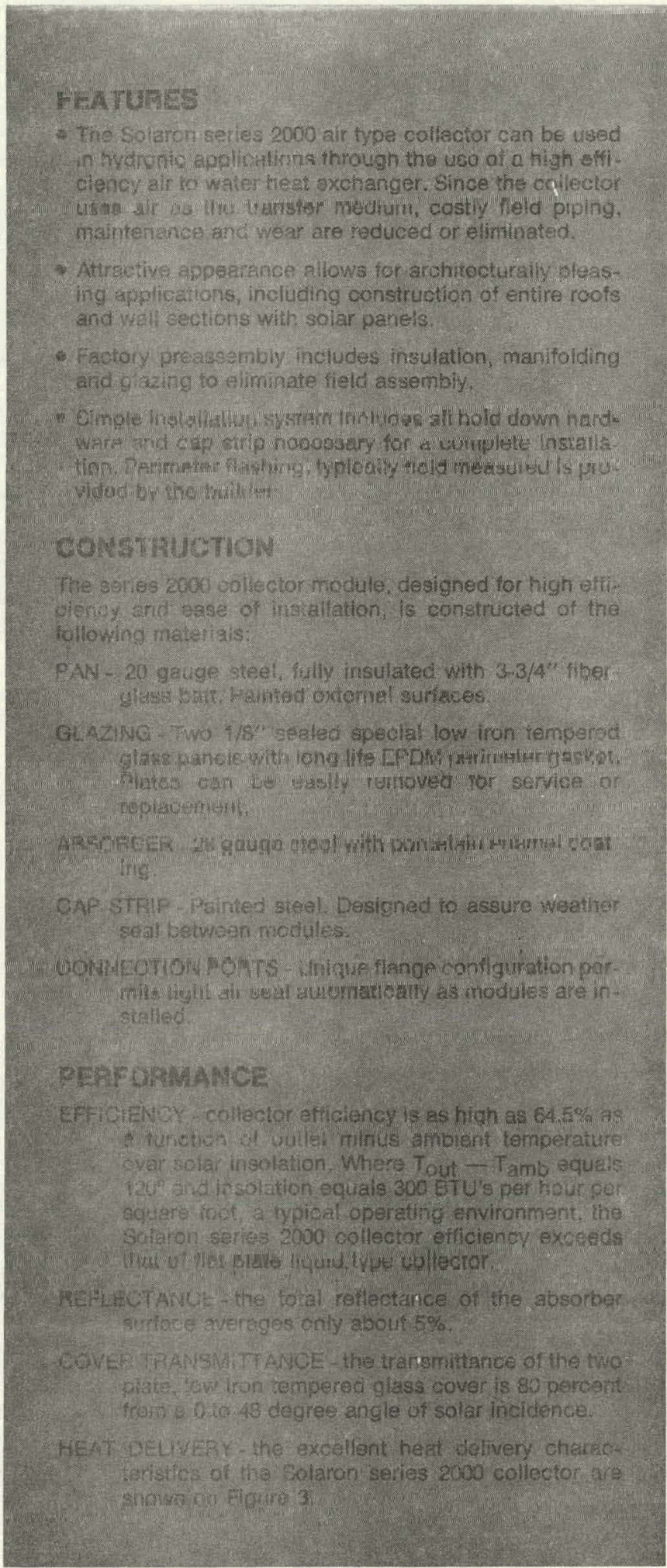




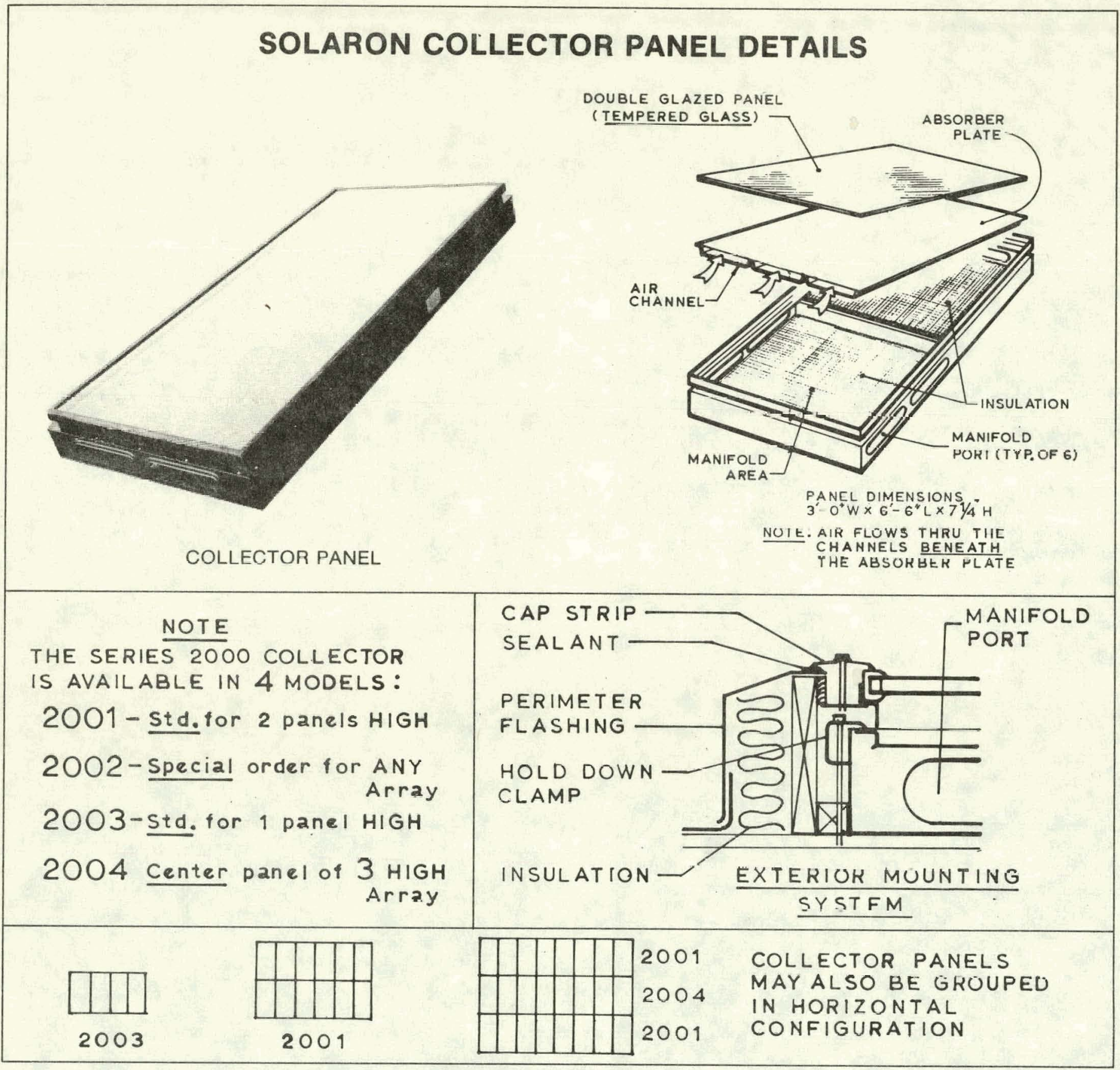

The Solaron series 2000 collector is flexible in application. The modules can be installed on a roof section, wall section or free standing roof frame.

The collectors are installed as shown in the mounting system details above. Return and supply air is provided by simply installing a standard starting collar on the bottom of the collector anywhere within the $29^{\prime \prime} \times 36^{\prime \prime}$ manifold area, thus collars can easily be located to clear roof trusses or wall studs. Perimeter flashing is field measured and installed to complete the system.

Other product information:

COLLECTOR WEIGHT - 153 poundS

INSTALLED DIMENSIONS - $36^{\prime \prime} \times 78^{\prime \prime}$, center to center

PORT NET FREE AREA - 26.7 square inches each

PORT END CAPS \& PORT GASKETS - provided by Solaron as required 


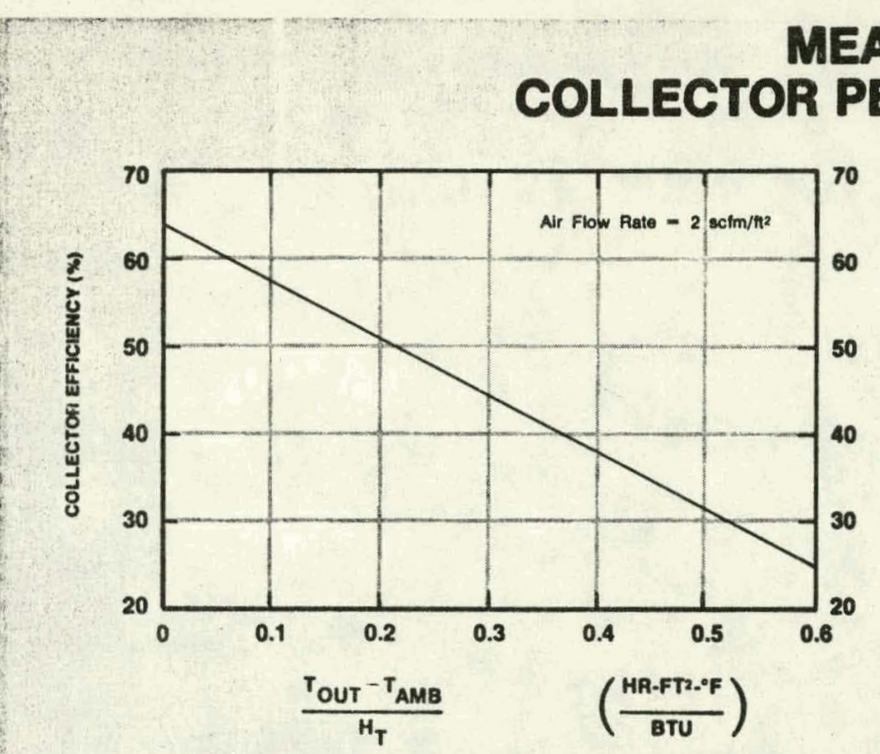

A-Collector efficiency as a function of outlet minus ambient temperature over insolation.

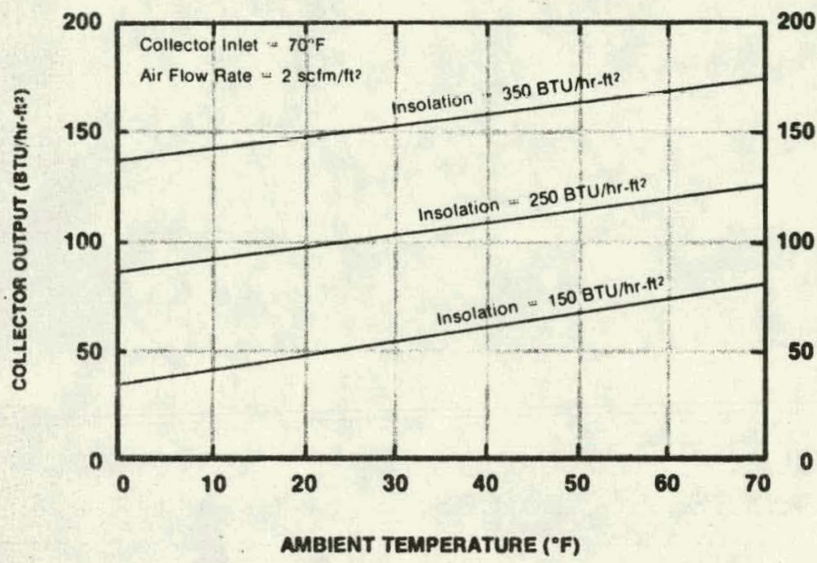
C-Collector heat delivery as a function of outdoor temperature for various
solar inputs.

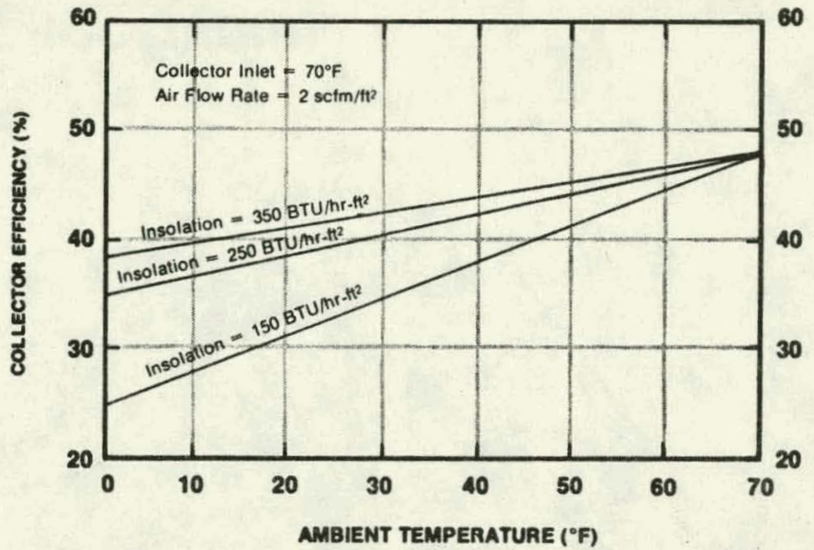

B-Collector efficiency as function of outdoor temperature for various solar inputs.

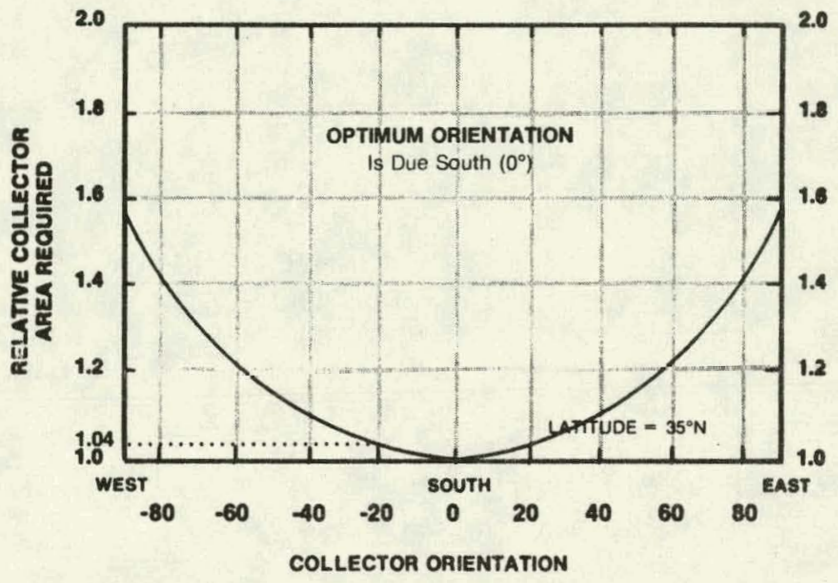

D-Effect of collector orientation on total system performance of a typical Installation at $35^{\circ} \mathrm{N}$ latitude. (J. D. Balcomb, J. C. Hedstrom, B. T. Rogers "Design Considerations of Air Cooled Collector/Rock-Bin Storago Solar Heating Systems," prosented at 1975 ISES LOS Angeles Meeting. Aug. 1975

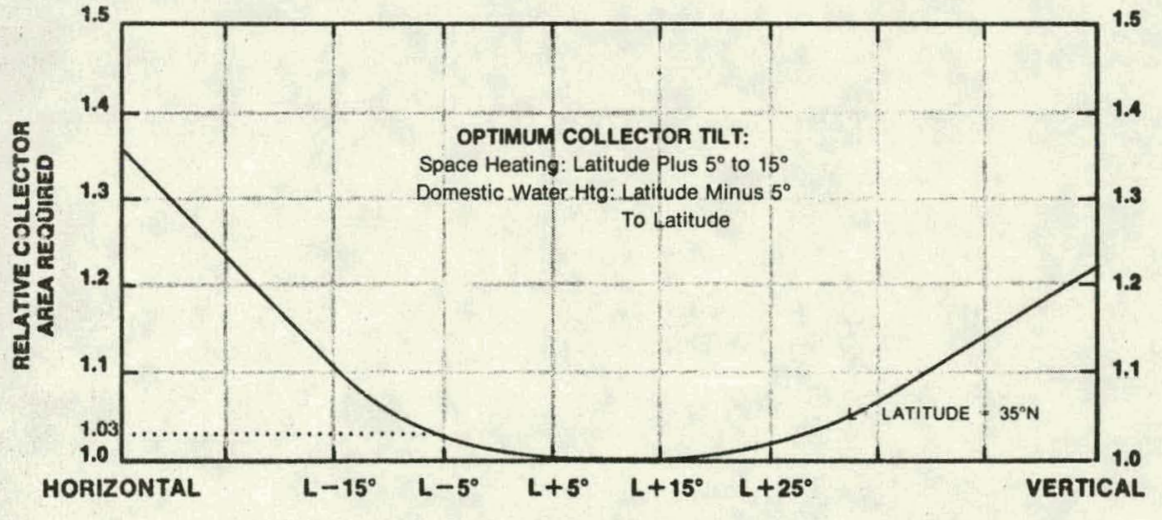

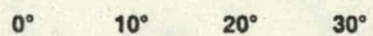

COLLECTOR TILT

E-Effect of collector tilt on total system periormance for a typical installation at $35^{\circ} \mathrm{N}$ latitude (J. D. Balcomb, J. C. Hedstrom, B. T. Rogers "Design Considerations of Air Cooled Collector/Rock-Bin Storage Solar Heating Systerns," presented at 1975 iSES LOS Angeles Meeting, Aug. 1975)

"Measured according to the guldelines set forth in ASHRAE proposed standard 93-P (Jan. 15, 1977) "Methods of Testing to Determine the Thermal Performance of Solar Collectors". 


\section{TYPICAL COLLECTOR INSTALLATION}

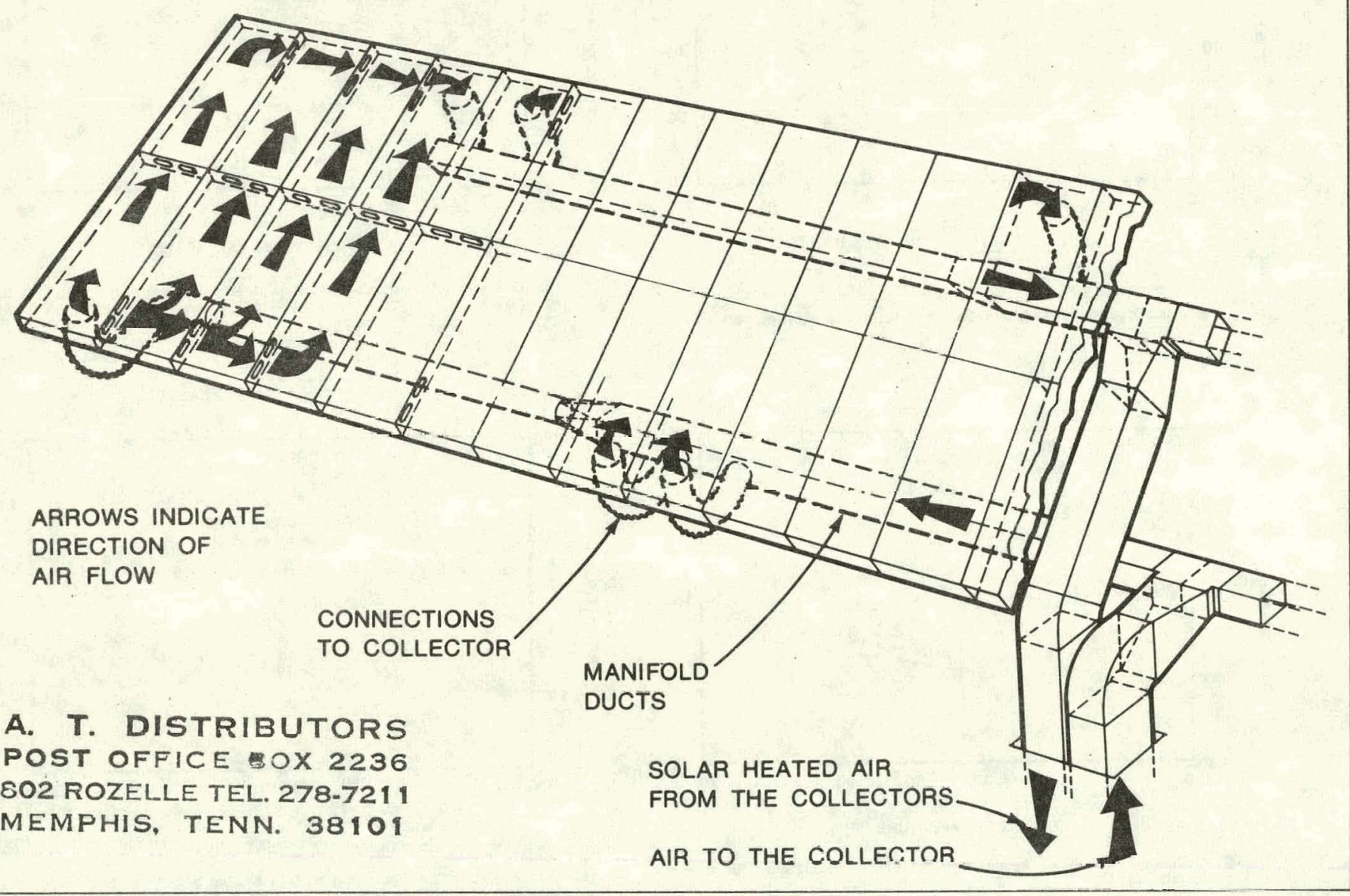

The Soleron acrics 2000 colar collecter can bo installen in aither a horizontal pr vertical position, Installation can be efficiently accomplished by a two-man crew. No special tools or installation iechniques are required

The optintal ail llow rale llwuwgh the collector i3 2 ECFM/ft? Tho deelgn static pressure is $0.23^{\prime \prime}$ when the collecturs dre ducted as shown above.

An A Mpnaial order basie, Solaron can provide rellecters with precut manifold openings and manifold ports omitted where specified to further reduce field installation time.

Solaron Corporation provides mechanical enginesring and field services to assist the local engineer and HVAC contraclor in design and installation.

Fer,ndditional information on the Solaron collerthr ann related Air Handling and Automatic Control systums, wuntast Golaron Corporation Marknting Servires.

SOLARON CORPORATION, MARKETING SERVICES 300 GALLERIA TOWER, 720 SO. COLORADO BLVD., DENVER, COLORADO 80222 303-759-0101 
COLLECTOR INSTALLATION MANUAL 


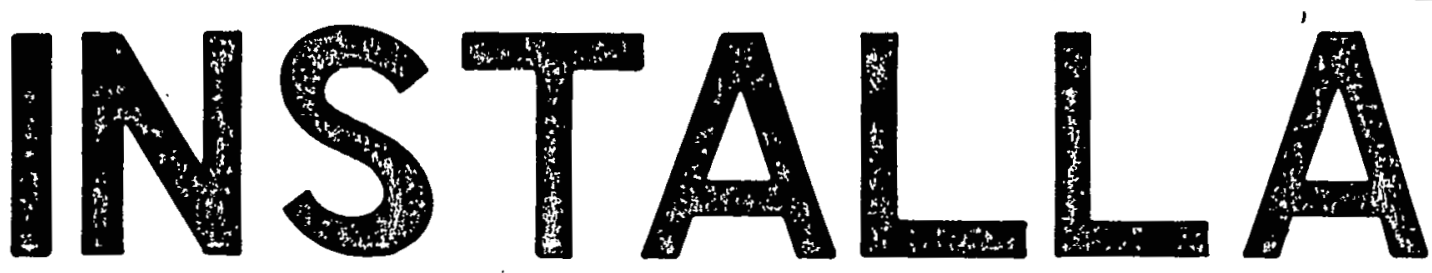

S.O.L.A.R. 700.00 .100 Revision 1 $3-77$

$$
\begin{array}{r}
\text { Series } 2000 \\
\text { COLLECTOR } \\
\text { PANELS }
\end{array}
$$
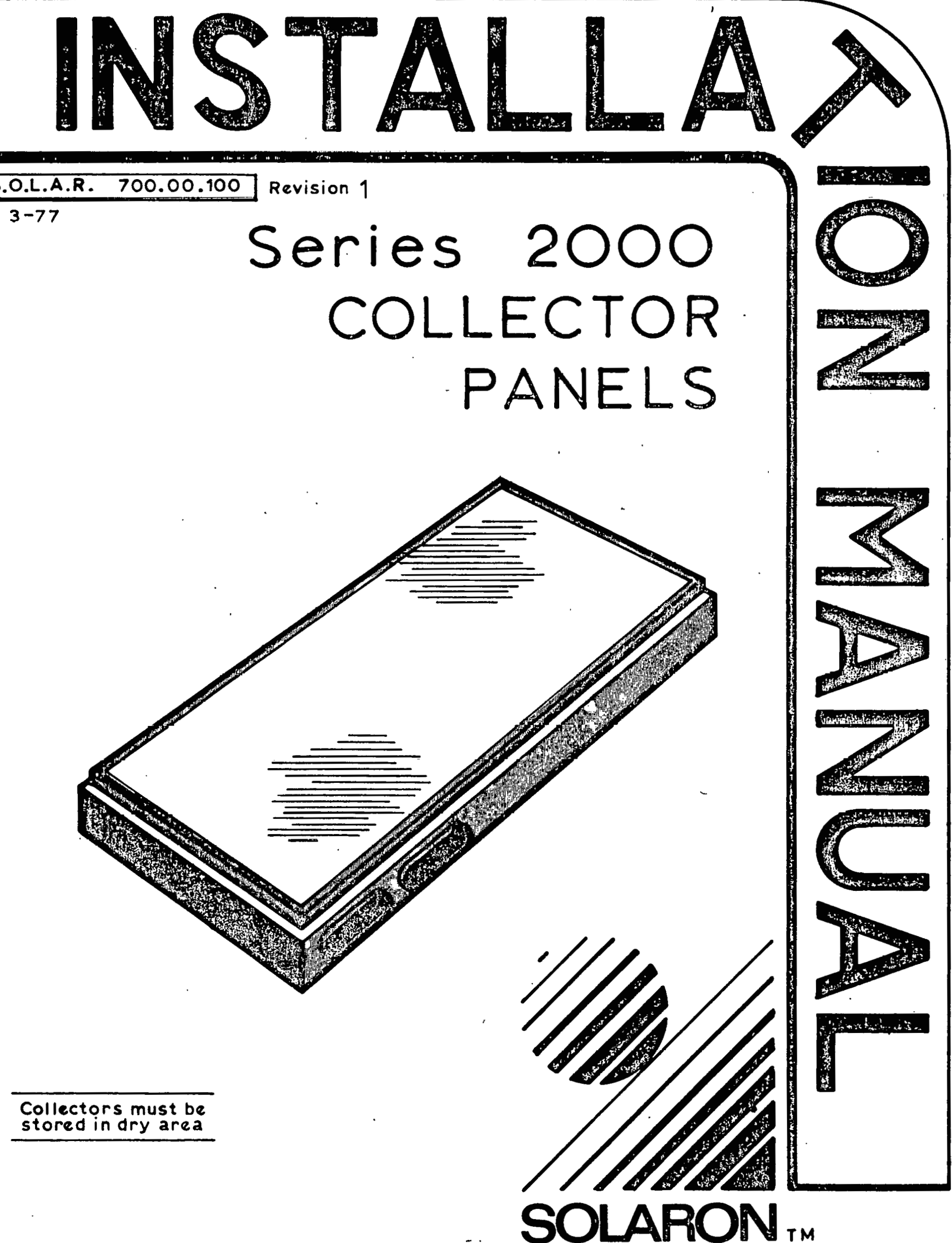


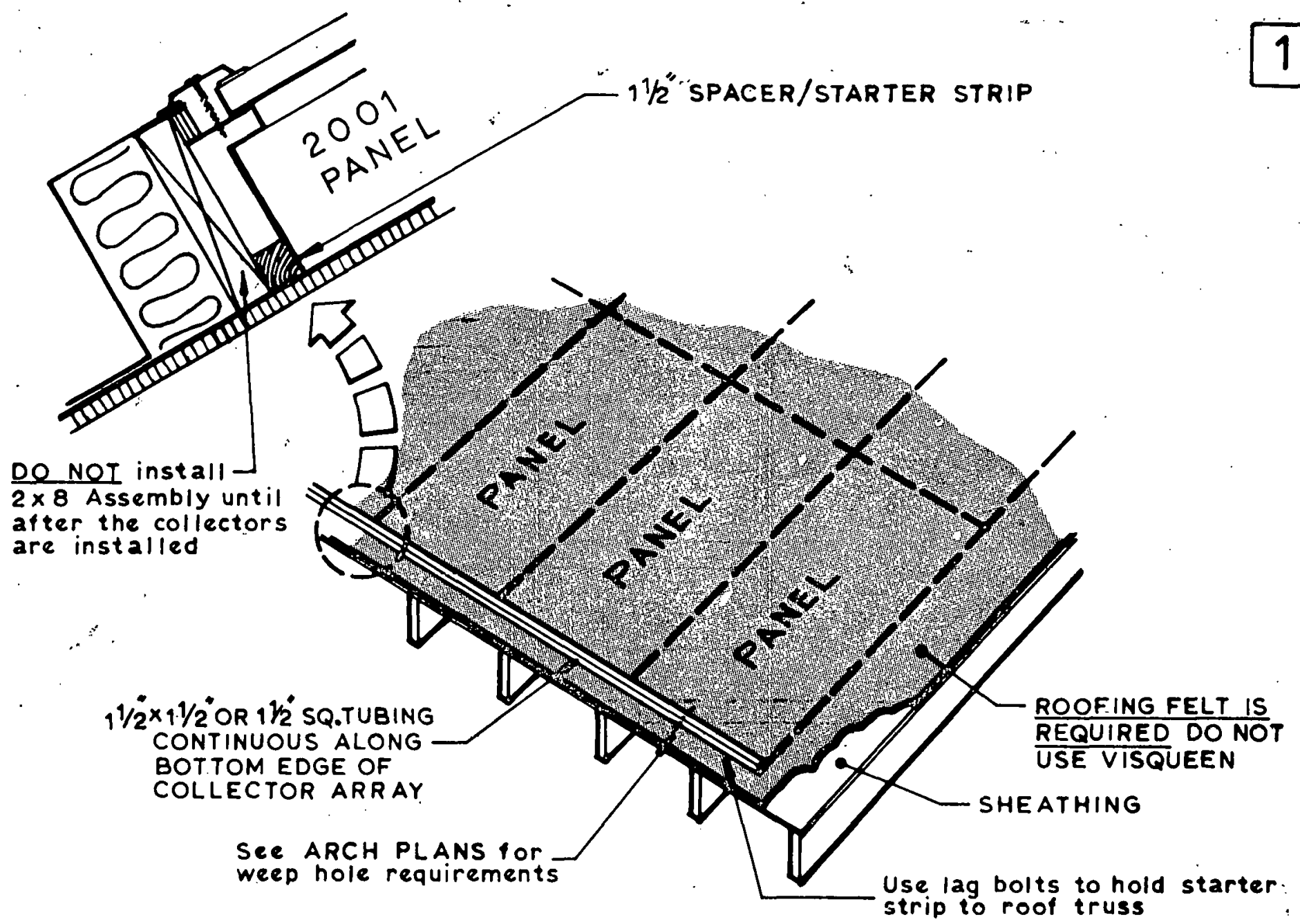

\section{DWG. 1 STARTING PANELS SUPPORT STRIP}

\section{STEP \#1}

The builder and/or framer must install the roofing felt and the $1-1 / 2$ " $\times 1-1 / 2$ " starter strip at the bottom edge of the collector array as shown above, BEFORE any collector panel installation is started. This strip serves as support for bottom row of collectors until hold downs are installed and also is used to ensure proper alignment of the entire collector array. The collector array must be laid out so that it will fit on the roof with 6" clear on all sides for cap strip support and perimeter insulation. (see.Drawing \#2). Do not install 1-1/2" $\times 7-1 / 8^{\prime \prime}$ perimeter frame prior to collector mounting.

\section{RECOMMENDED TOOL LIST}

$1 / 4^{\prime \prime}$ or $3 / 8^{\prime \prime}$ reversible, variable speed electril drill, sabre saw, reciprocating saw or skill saw, medium slot-type screw driver, $50 \mathrm{ft}$. or longer tape measure, $10 \mathrm{ft}$. to $16 \mathrm{ft}$. tape, chalk line, square (18"x24"), 2-7/16" hex sockets for 1/4" driver, two

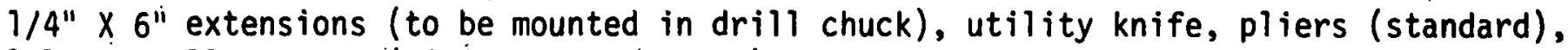
Solaron pull-up tool ('limited application), come-along with $30^{\prime}$ min. cable length, sunglasses (polarizing), work gloves, safety helmets, safety ropes \& accessories (if needed), ladders (appropriate for height of array being worked on), roof jacks (if required), machine for lifting ccollector onto roof (crane, front loader, etc.), matches or cigarette lighter, caulk gun, left \& right snips, scratch aw1, 5/16". dia. drill bit 10" long, Scribe. 

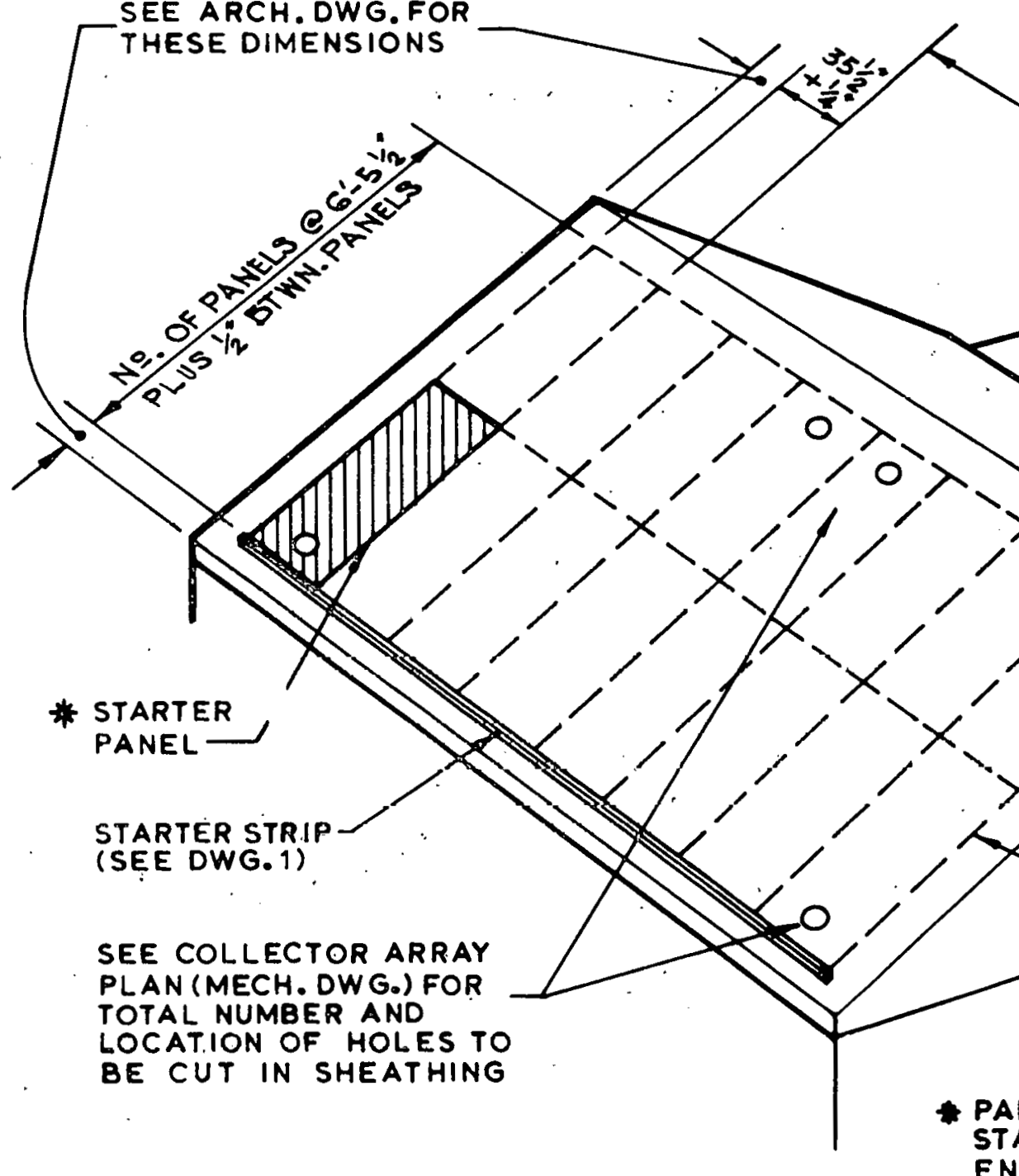

PANEL

STARTER STRIP

(SEE DWG.1)

SEE COLLECTOR ARRAY

PLAN (MECH. DW G.) FOR TOTAL NUMBER AND

LOCATION OF HOLES TO

BE CUT IN SHEATHING

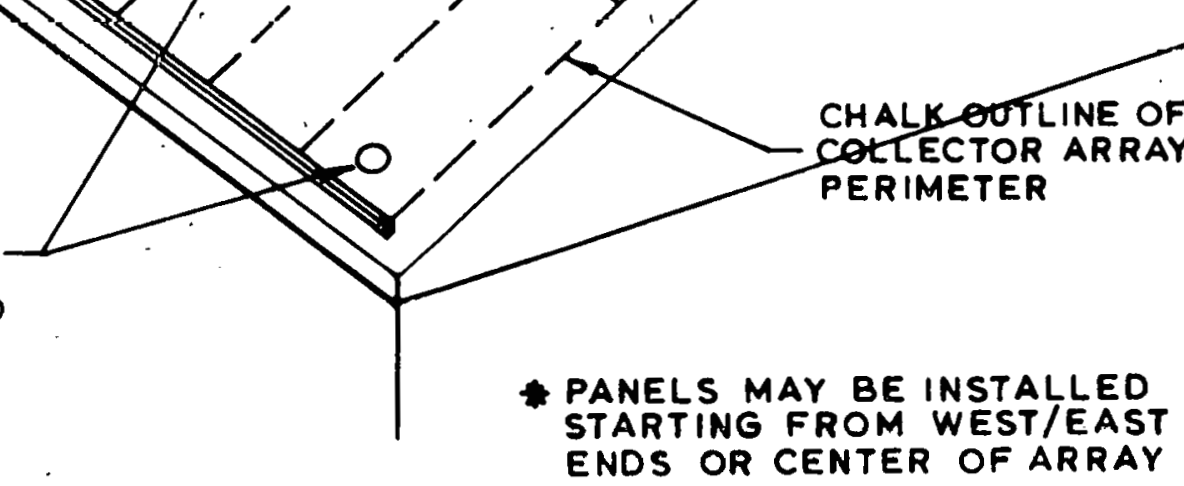

\section{DWG. 2 ARRAY LAYOUT ON ROOF}

\section{STEP \#2}

Chalk outline of actual perimeter of the collector array onto the roofing felt, as shown above, making certain that your lines are square and plumb.

\section{STEP \#3}

From plan of collector array (mech. drawing) determine location of holes to be cut in sheathing. These holes permit access for starting collar connection between panel and duct work (see drawing \#3 \& \#5). The holes in the collector panels can only be cut in the manifold section as shown in drawings 3 and 5 . This must be coordinated with roof sheathing holes. Cut roof sheathing holes $2 "$ in diameter larger than collar (i.e. plans show an 8" collar, cut a 10" hole. Hole may be either round or square.

(C) Copyright $1976 \quad-$ SOLARON CORPORATION TM 


\section{NOTE}

TILT PANEL TO ALLOW ACCESS

FOR CUTTING HOLE IN BOTTOM

(DUCT CONNEC TION). DO NOT

INVERT PANEL.GLASS IS NOT

CLAMPED IN PLACE AND COULD

DROP FROM FRAME WITH

IMPROPER HANDLING

LAY BEAD OF DOW-CORNING

CAULKING NQ. 732-CL-11 UNDER COLLAR FLANGE FOR

AIRTIGHT SEAL

SEE COLLECTOR ARRAY

PLAN (MECH.PLAN)

FOR HOLE SIZE

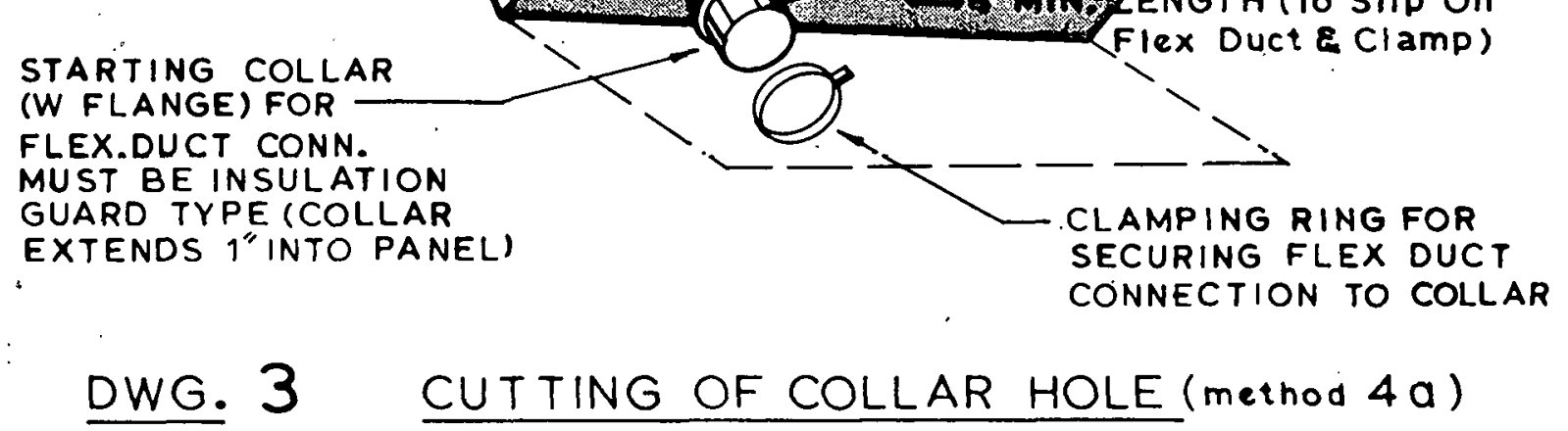

STEP \#4

Collar holes to be cut in the collector panels by one of two methods as follows:

(a) Should the location of the mounted panel prevent easy access for hole cutting use method shown above for cutting hole before the collector panel is mounted to the roof sheathing. Make sure the hole you cut in the bottom of the panel and through insulation lines up with hole already cut in the roof sheathing.

(b) After collectors are installed securely on the roof (as per Step \#5) cut the required holes in the bottom of each predetermined collector panel (confirm the size \& location of each hole with the mechanical plans). Any method of collar mounting requires caulking with Dow-Corning \#732-CL-11 to form air-tight joint between collar flange and the collector. 


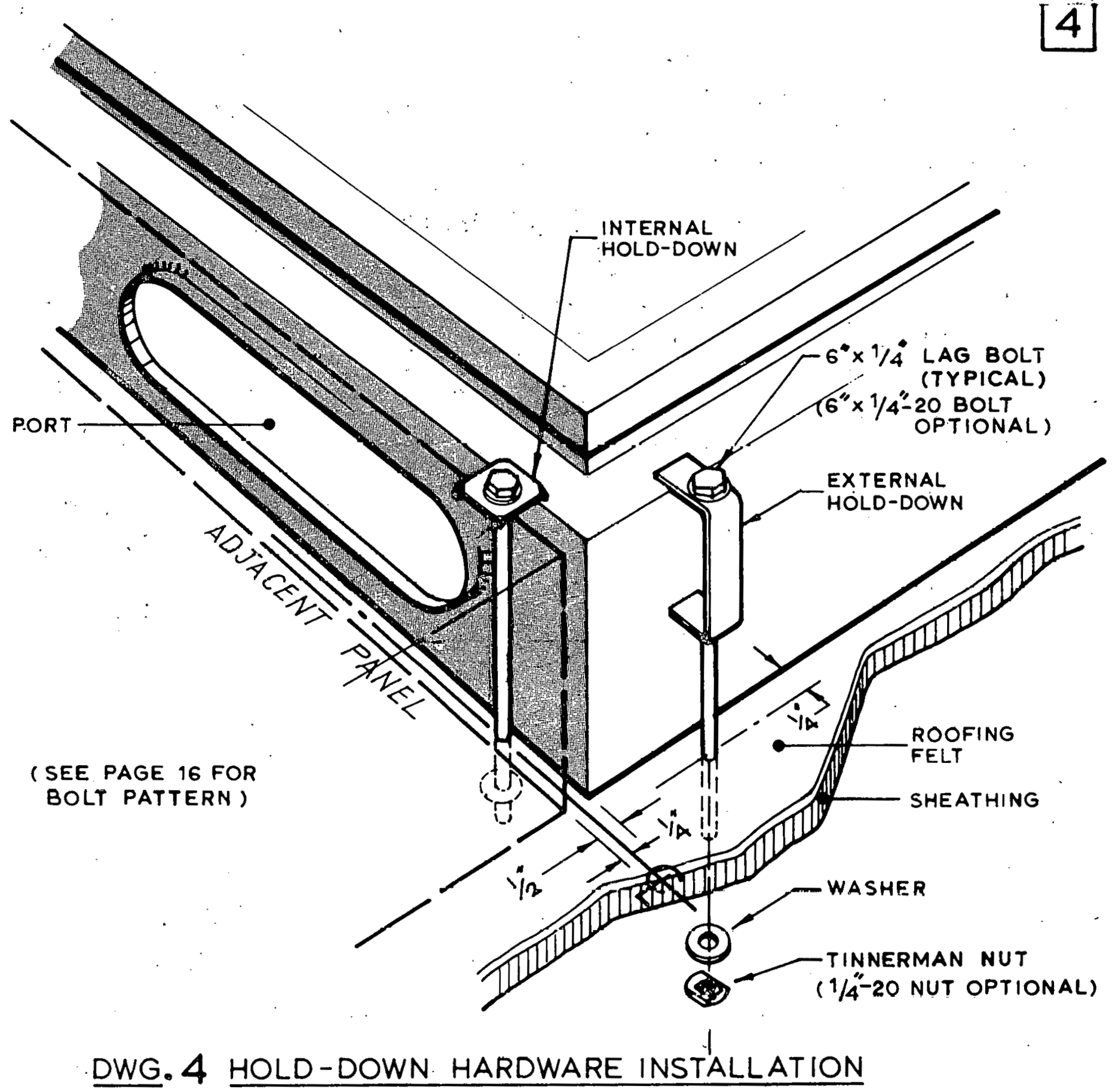

\section{STEP \#5}

Referring to drawings 4 and 5 , drill 5/16" holes in roof sheathing for collector hold downs in designated places, as shown in drawing 5. Secure exterior hold downs after collector is in place. When two panels are mated, drill 5/16" holes for the interior hold downs after the adjoining collector is pulled tightiy against the port gasket. The gasket must be kept clean and applied to a clean surface. 


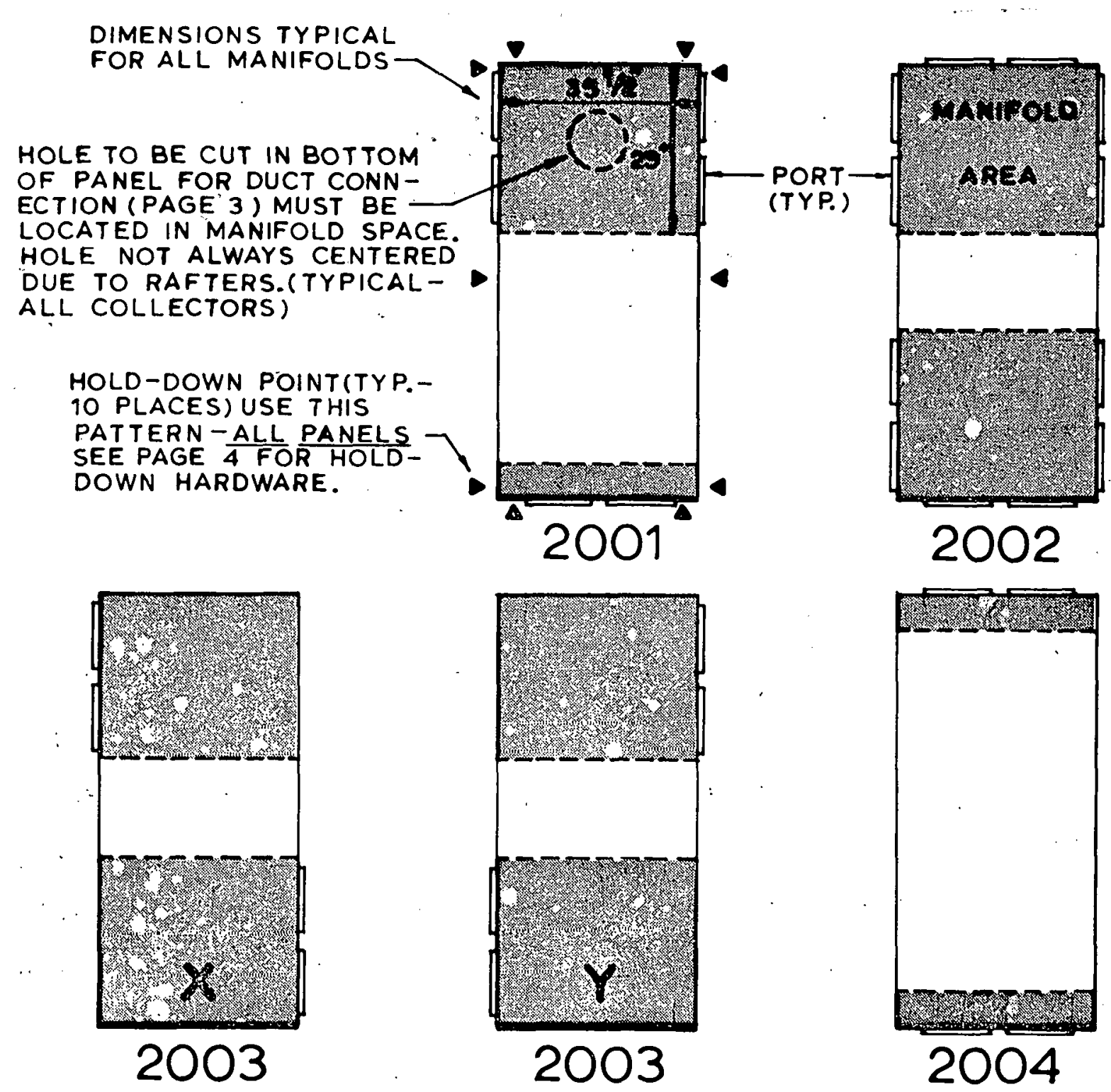

DWG. 5 HOLD-DOWN HARDWARE ATTACHMENT POINTS

\section{STEP \#5 (Cont.)}

Place each bolt with clamp into its proper hole (external hardware around the perimeter and internal hardware between collector panels - see drawing 4). One person must put a washer and a lock nut onto the same bolt from the attic side of the roof and tighten. A $7 / 16^{\prime \prime}$ socket \& 7/16" open end wrench or adjustable wrench is recommended for tightening hold down bolts. Internal hold down should "dimple" collector metal. Exterior hold down should catch rivet. Should the location of the collector place the hold down bolt directly over a structural member you have two methods of mounting. 1) Discard the $6 " \times 1 / 4^{\prime \prime}$ bolt and use a 6 " $\times 1 / 4$ " $1 \mathrm{ag}$ bolt. Tighten directly into the structural member. 2) Discard the $6^{\prime \prime} \times 1 / 4^{\prime \prime}$ bolt and drill a 5/16" hole all of the way through the structural member. Use $1 / 4^{\prime \prime}$ all-thread to the required lenght and mount as described above. CAUTION be sure the structural integrity of a member is not affected by this method of mounting BEFORE you start drilling: 


\section{Lag Hold-Downs}

Place the hold down hardware (i.e. 6" $\times 1 / 4^{\prime \prime}$ lag bolt with the appropriate interior or exterior clamp) at the attachment points shown in drawing 5." Screw the lag bolt into the roof sheathing by using a $7 / 16$ " hex socket (on a $1 / 4$ " extension) and a $1 / 4$ " or $3 / 8$ " electric drill. Interior hold down clamps must dimple the collector metal to hold properly. Exterior clamps should catch one of the rivet heads on the collector. After lags have been drilled into place, a washer and tinnerman must be placed on the tip of lag from the underside of the roof.

\section{Screw Hold-Downs}

After placing collector in position, secure in place using 4 lag bolts or bolts. Using bugle-head drywall screws ( $23 / 8^{\prime \prime} \# S 12$ or 6-20 X $15 / 16^{\prime \prime}$ flooring screws) drill into the backside of the collector and roof sheathing from the attic area. Eight (8) screws are required; four on each side near the edge of the collector. This procedure is recommended for very steep roof angles. DO NOT use sheetmetal screws for this application. Eight washers are also required and should be placed on the screw before drilling.

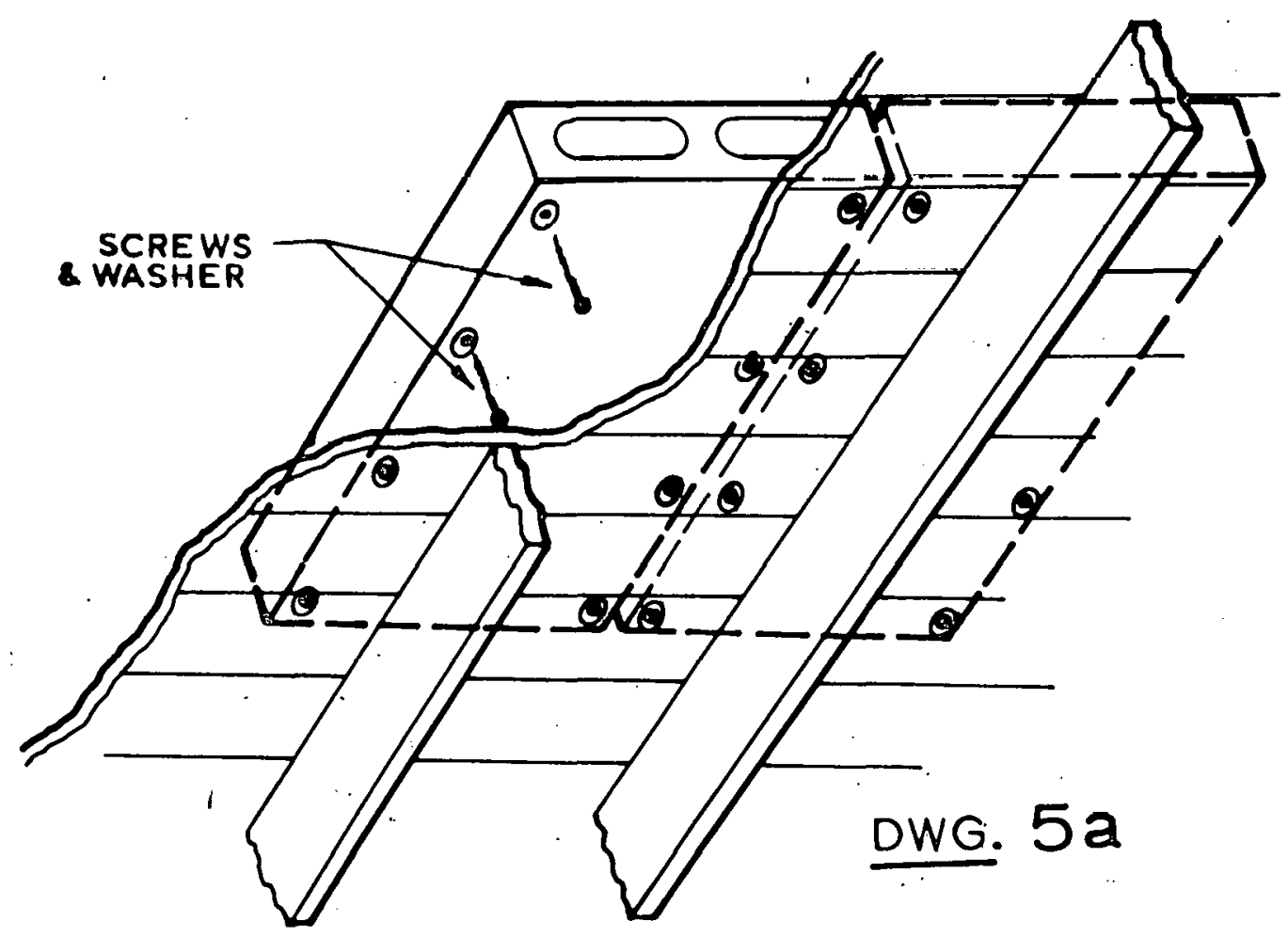




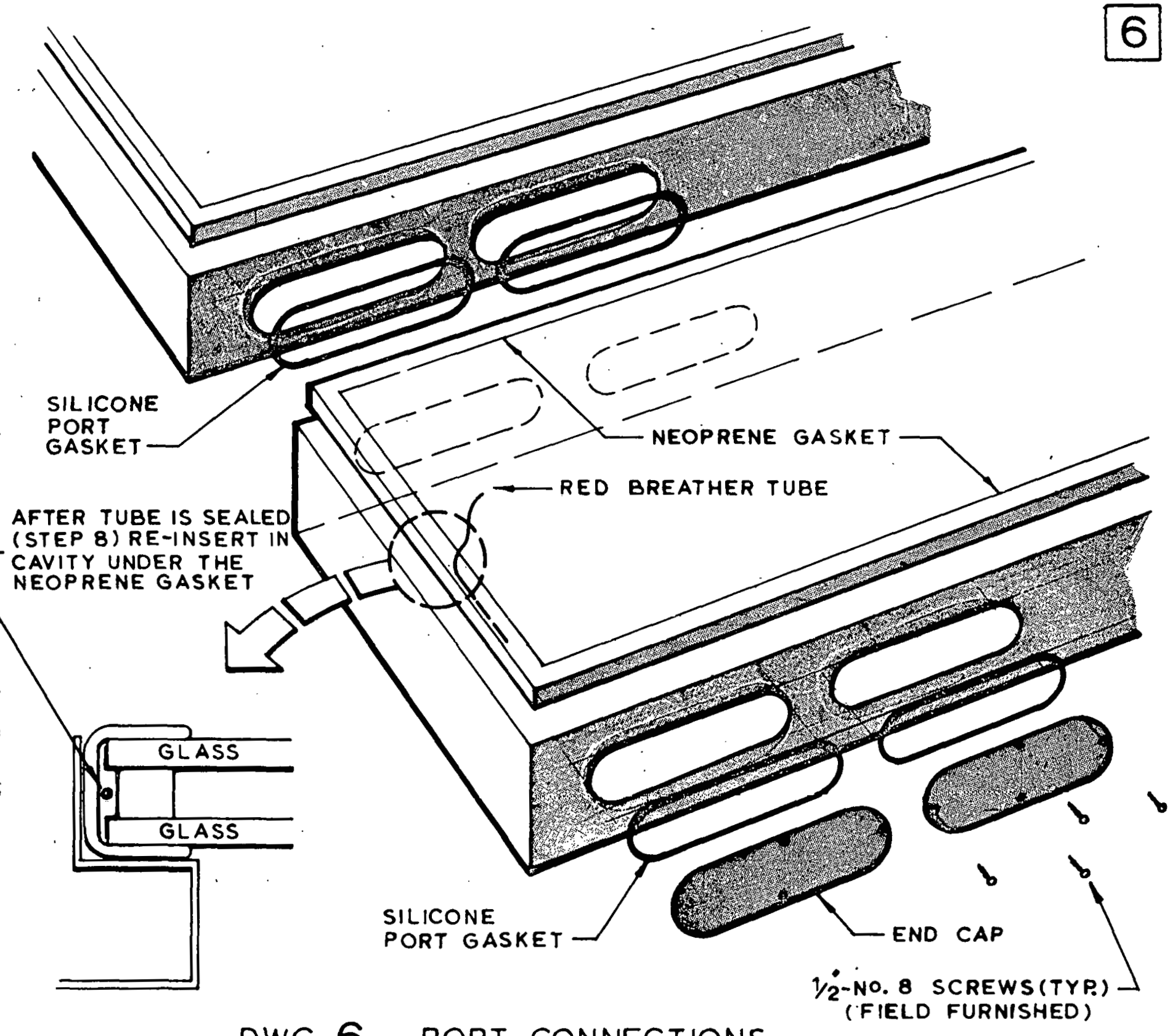

STEP \#6

DWG. 6 PORT CONNECTIONS

Install the silicone gasket and attach end cap with screws to the collectar panel, as shown above, making sure you obtain an airtight seal. As each panel is positioned in its location be sure that the gasket has been properly mounted around each port that will be immediately mated to an adjacent collector panel port. The gasket must seat evenly around the port to insure an airtight seal.

STEP \#7

Lay a bead of Dow-Corning \#732-CL-11 caulking compound around the opening in the bottom of the collector panel as shown in Drawing 3. This is to insure an airtight seal between the collector and the starting collar flange. Mount the starting collar in such a manner that will make a solid, airtight connection.

\section{STEP \#8 Relief Tube -}

When collector is in place and secured, but before cap strip is installed, check red nylon pressure relief tube to make sure it is open so that pressure between panes of glass has had time to equalize to local atmospheric pressure. Next, seal tube by tyinn knct in tube and permanently sealing end by melting and squeezing the open end closed. Now place closed tube under neoprene gasket along the edge of the glass (see detail on dwg 6) $\&$ return gasket to normal position. 


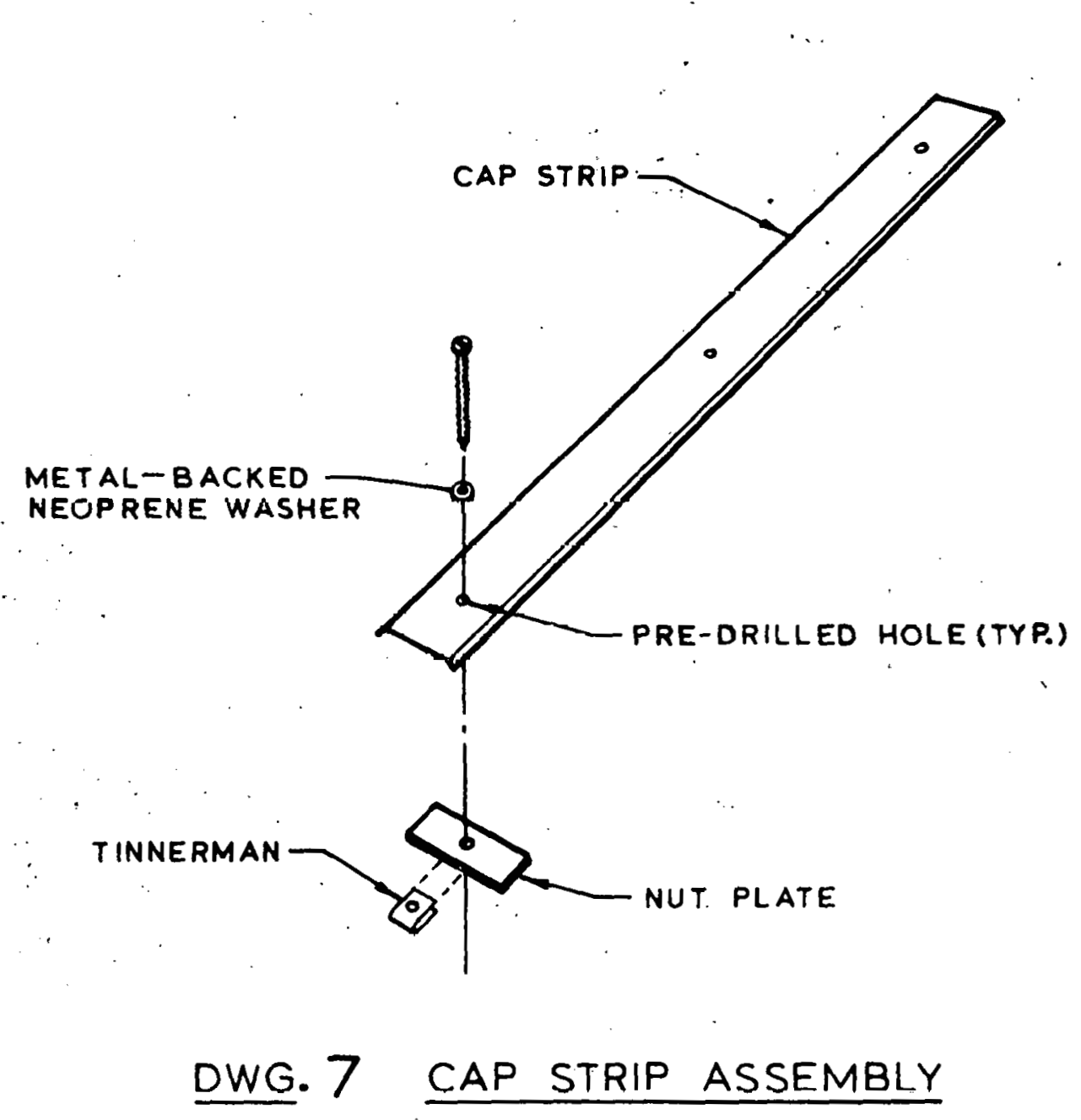

\section{STEP \#.9}

After all the collectors are in place and secured, coordinate with builder to install $1-1 / 2^{\prime \prime} \times 7-1 / 8$ " frame assembly around perimeter of array as per drawings 8 and 9 (mounting cap strip and flashing). Flashing must be installed before perimeter sealant and perimeter cap strip can be installed. 


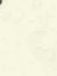
.

(

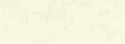
"L" COVER PLATE

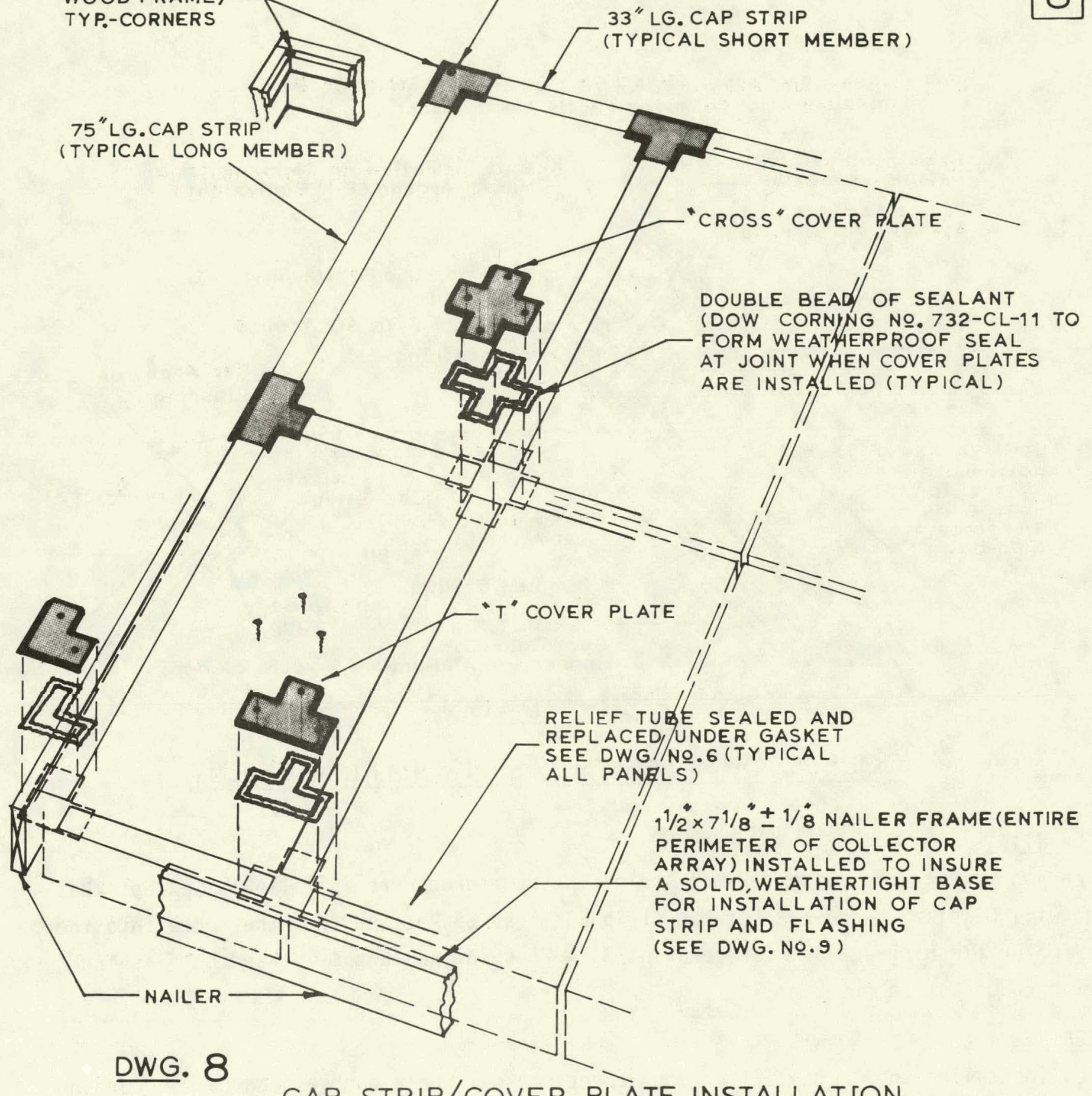
CAP STRIP/COVER PLATE INSTALLATION

\section{STEP \#10}

Referring to Drawings $7 \& 8$ start installation of cap strip. Cap strip is mounted with 2-1/2" screws and metal backed neoprene washer. Place screw with washer through predrilled holes in cap strip. See Drawing 7. Turn the screw into the tinnerman clip approximately 3 turns. Place cap strip so that each edge is lined up on collector glass gasket evenly with nut plates under glass enclosure lip. By pressing on the screw while turning to secure nut plate, you will keep nut plate straight so that it will secure itself under adjacent glass enclosure shelves. Cap strips between collectors should be mounted during collector installation to hold glass in place.

(c) Copyright 1976 SOLARON CORPORATION $\mathrm{MM}$ 


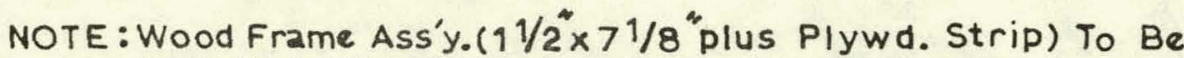
Installed After Collector Panels Are In Place

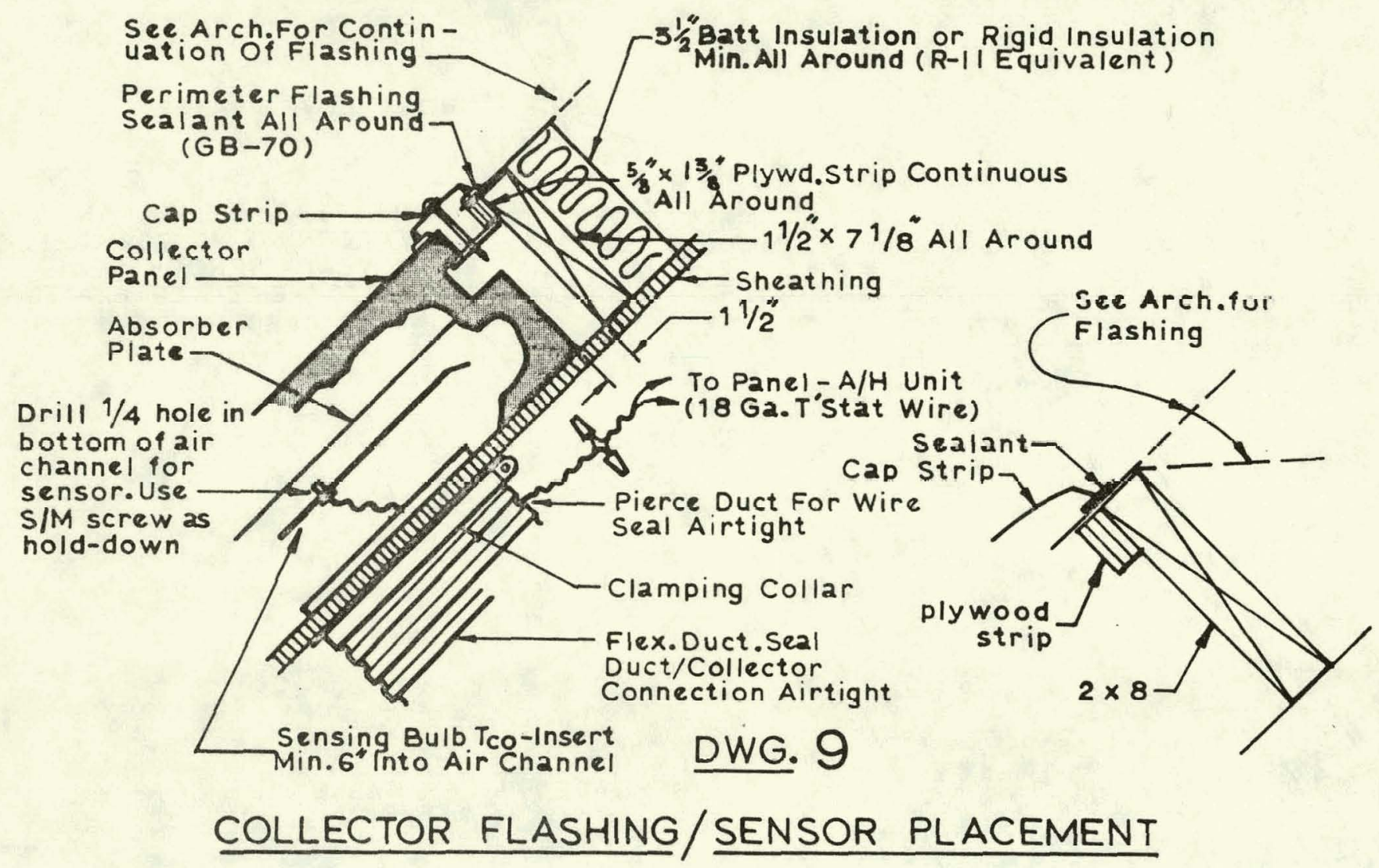

STEP $\# 11$

When you install the perimeter cap strip, the same procedure is followed, except that you will be placing one edge of cap strip on glass gasket and the other edge into the perimeter flashing sealant (See drawing 9). Flashing sealant is placed on flashing prior to cap strip mounting.

\section{STEP \#12}

When installing the "Cross, El or Tee" cover plates, run a double bead of Dow-Cornina 732-CL-11 silicone caulk on the cap strip as shown in Drawing 8. Instal1 5/8" Tec self-drilling screws in pre-drilled holes and tap into cap strip. A third hole must be drilled into the 90 degree $L$ in accordance with the wood backing to obtain a tight seal in the corners (see Drawing 8).

NOTE: 2-1/2" screws, metal backed neoprene washers, nut-plate and tinnermans \& 5/8" self-tapping screws furnished by Solaron. 


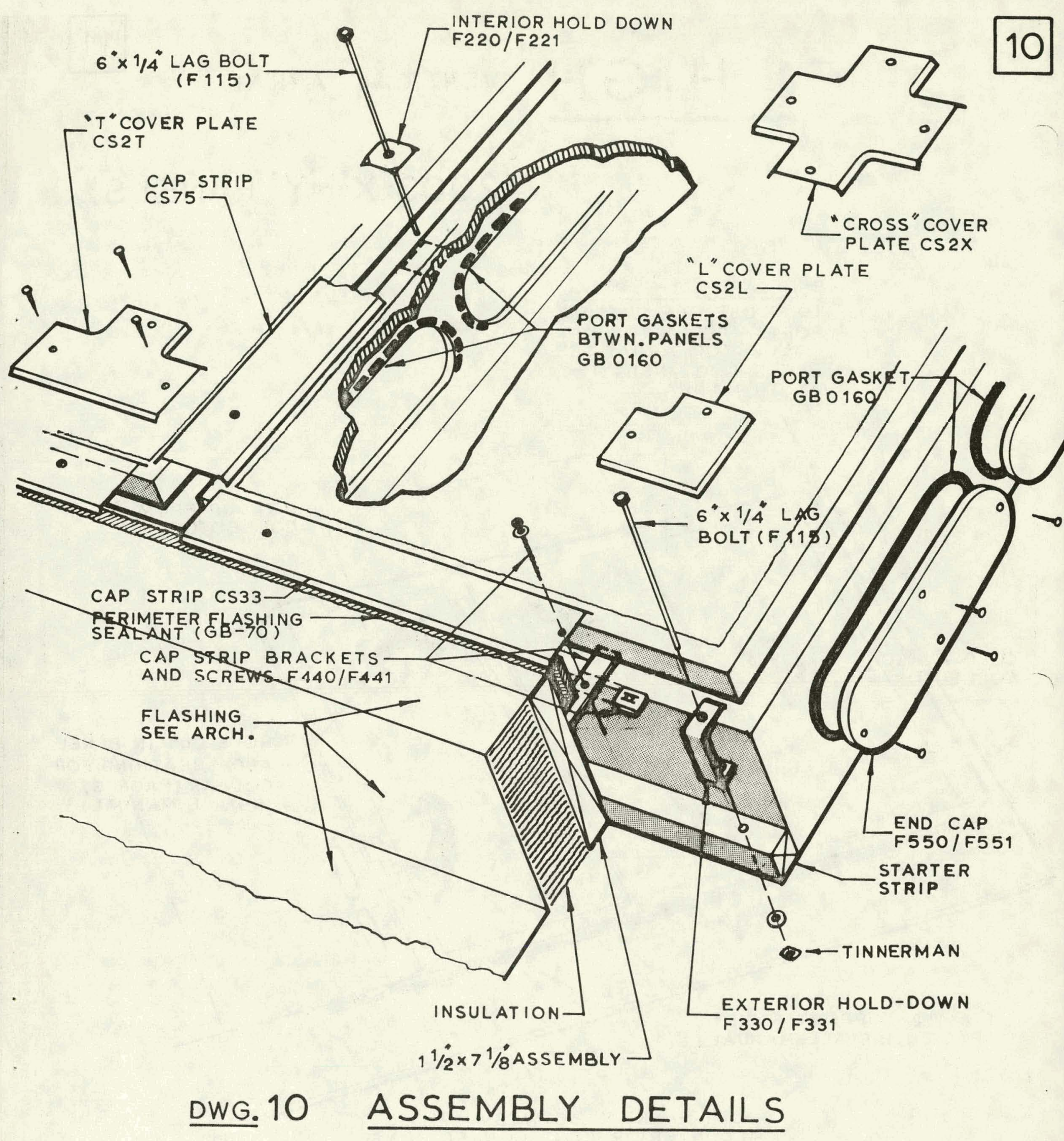




\section{(2003 "X"and Y" PANELS)}

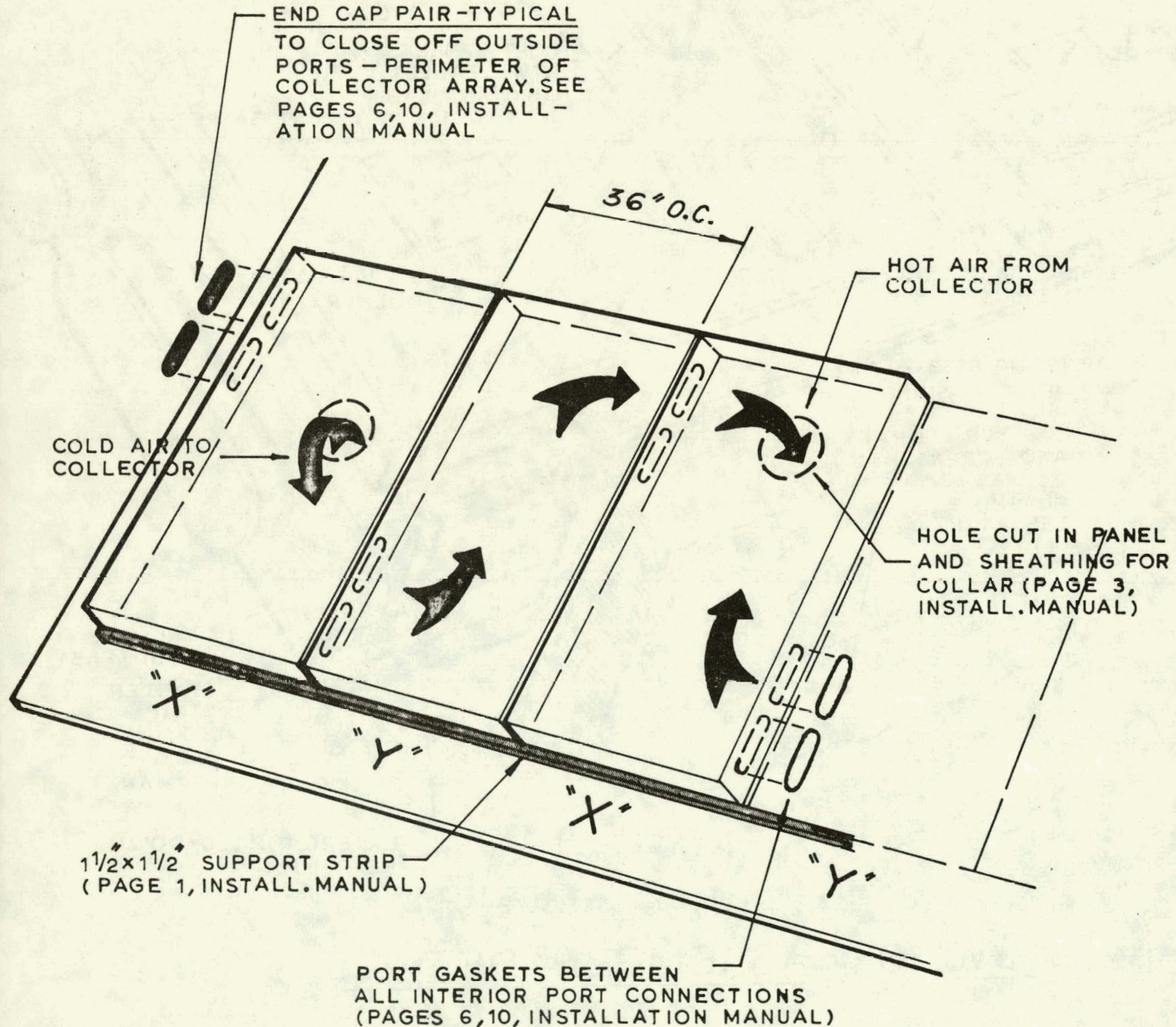

(PAGES 6, 10, INSTALLATION MANUAL)

SEE INSTALLATION MANUAL FOR ADDITIONAL INSTRUCTIONS 
END CAP PAIR-TYPICAL TO CLOSE OFF OUTSIDE PORTS-PERIMETER OF COLLECTOR ARRAY. SEE PAGES 6,10, INSTALLATION MANUAL

PORT GASKETS BETWEEN ALL INTERIOR PORT CON NECTIONS . SEE PAGES 6,10, INSTALLATION MANUAL

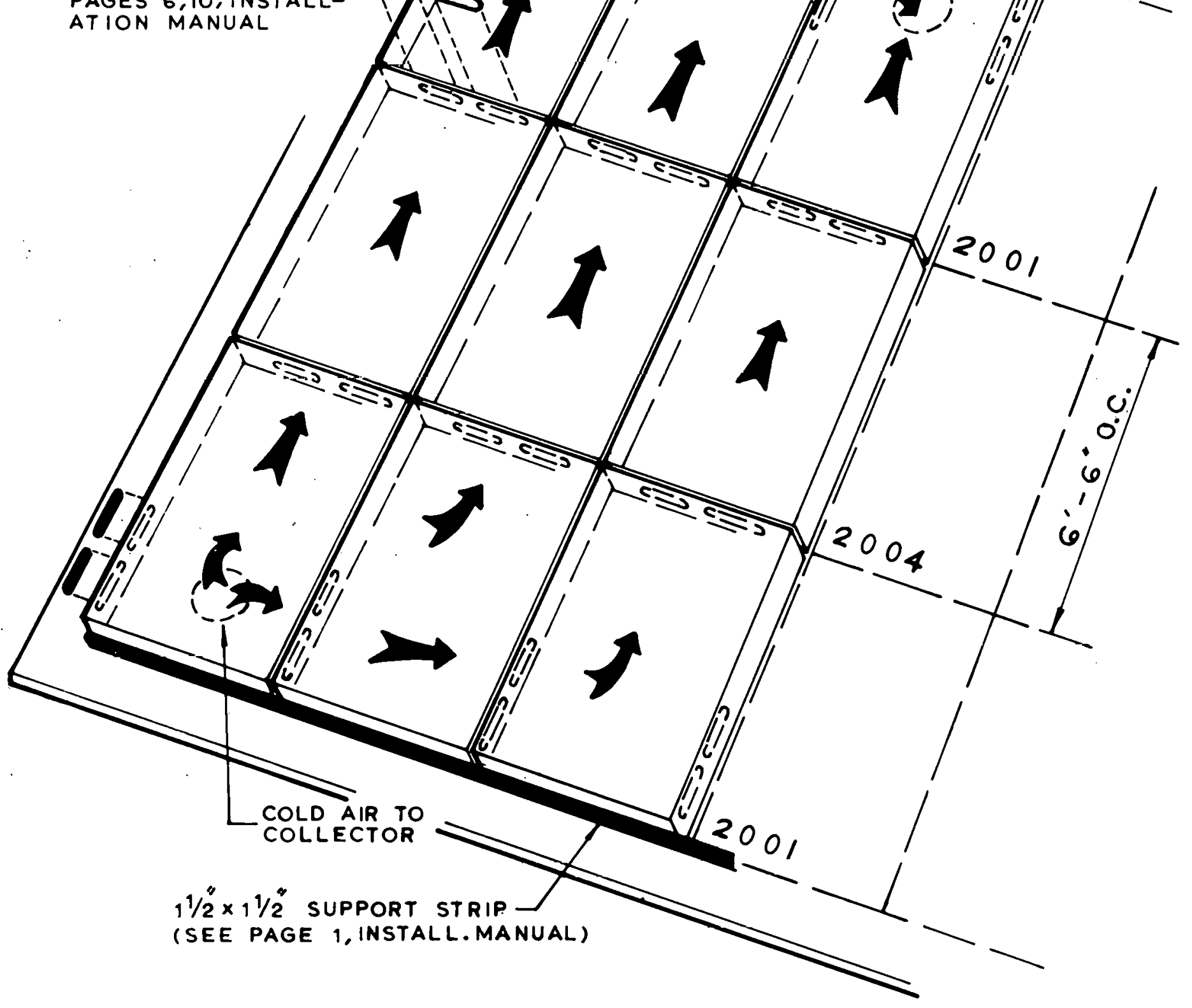

SEE INSTALLATION MANUAL FOR ADDITIONAL INSTRUCTIONS 


\section{(2001 PANEL)}

\section{ND CAP PAIR - TYPICAL \\ TO CLOSE OFF OUTSIDE}

PORTS - PERIMETER OF

COLLECTOR ARRAY.

SEE PAGES 6,10,

INSTALLATION MANUAL

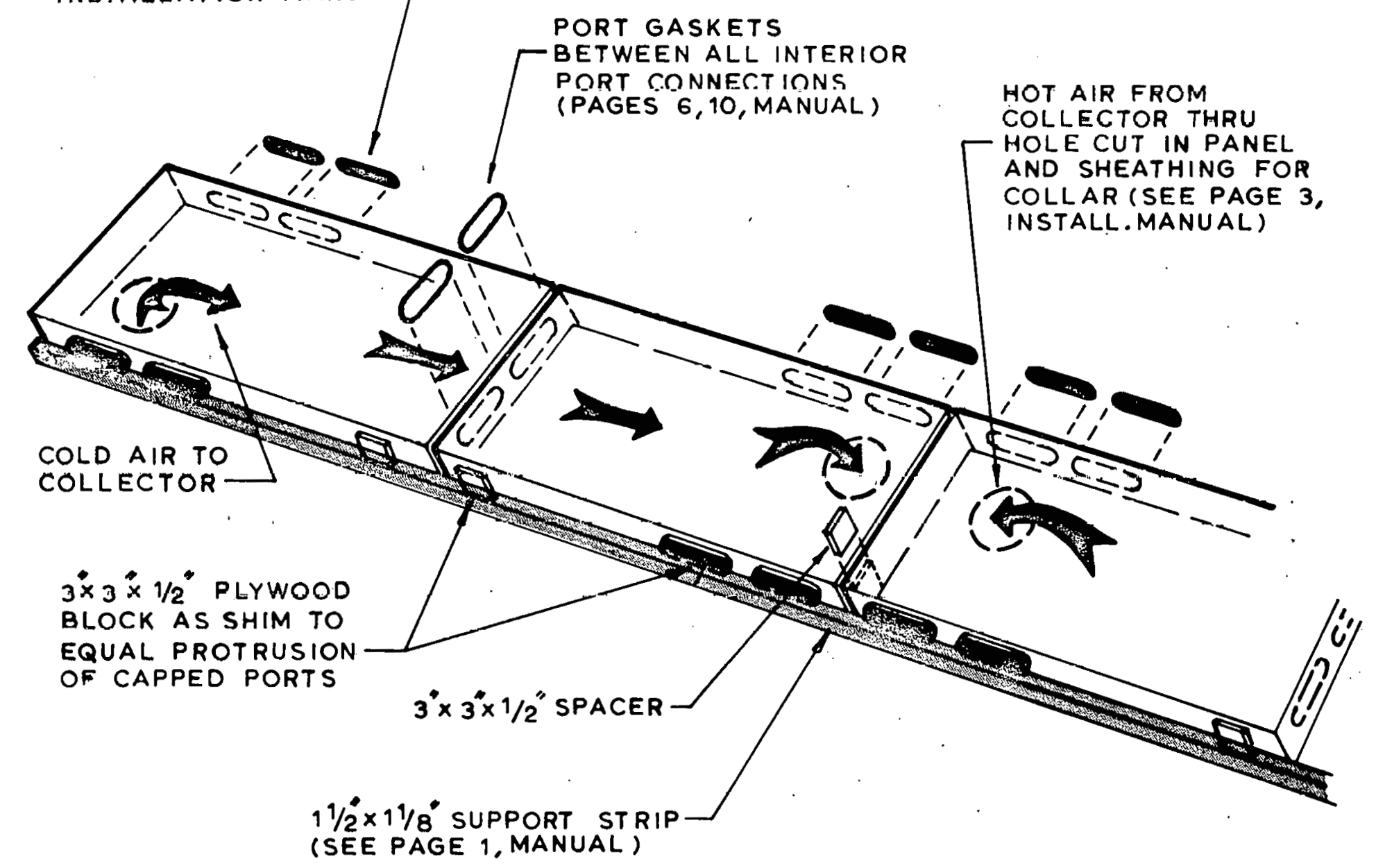

(3) 


\section{HIGH horizontal array 14}

( 2001 PANEL)

END CAP PAIR-TYPICAL

TO CLOSE OFF OUTSIDE

PORTS PERIMETER UF

COLLECTOR ARRAY. SEE

PAGES 6,10, INSTALL -

ATION MANUAL
PORT GASKETS

BETWEEN ALL INTERIOR PORT CONNECTIONS-7 (PAGES 6,10, MANUAL)
HOT AIR FROM

COLLECTOR THRU

HOLE CUT IN PANEL

AND SHEATHING FOR

COLLAR (SEE PAGE 3 ,

INSTALL.MANUAL)

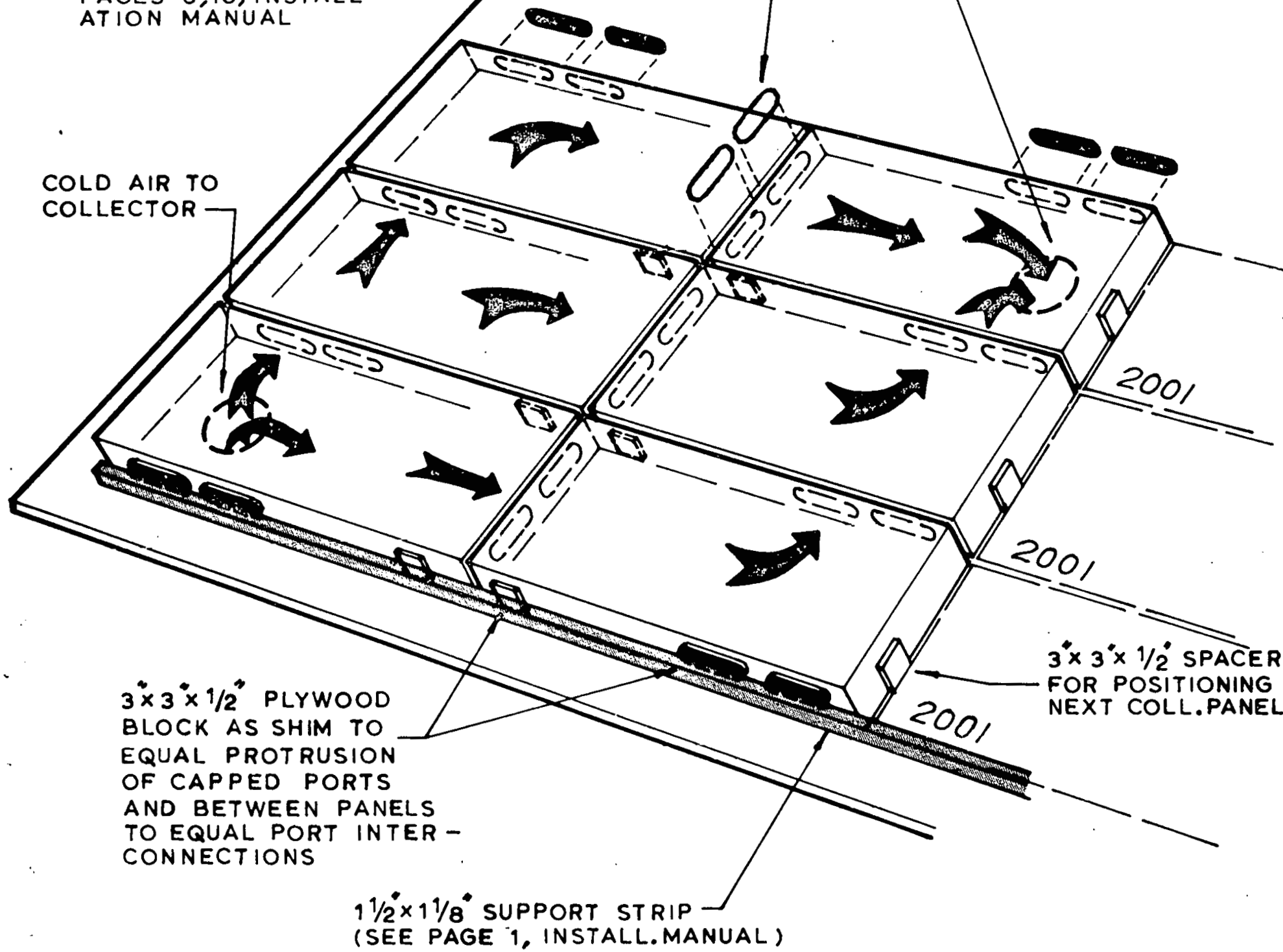

(SEE PAGE 1, INSTALL.MANUAL)

SEE INSTALLATION MANUAL

FOR A.DDITIONAL INSTRUCTIONS 
AIR HANDLER INSTALIATION MANUAL 


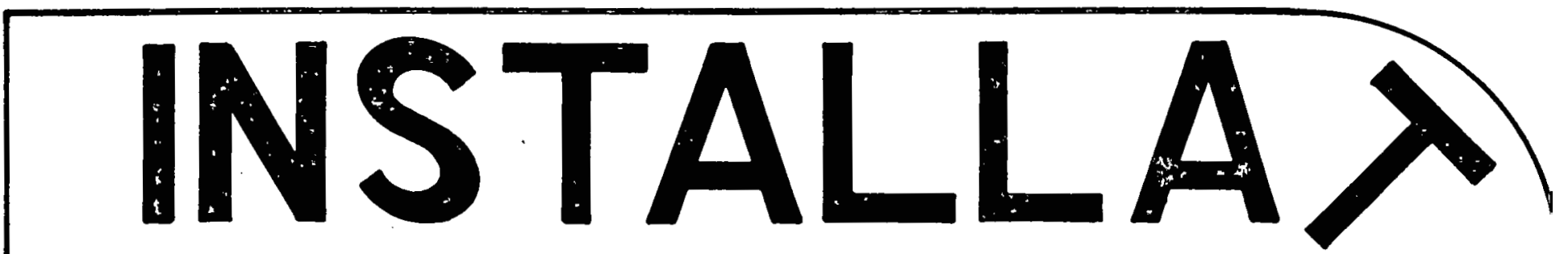

S.O.L.A.R. 900.40 .050 $6-1977$

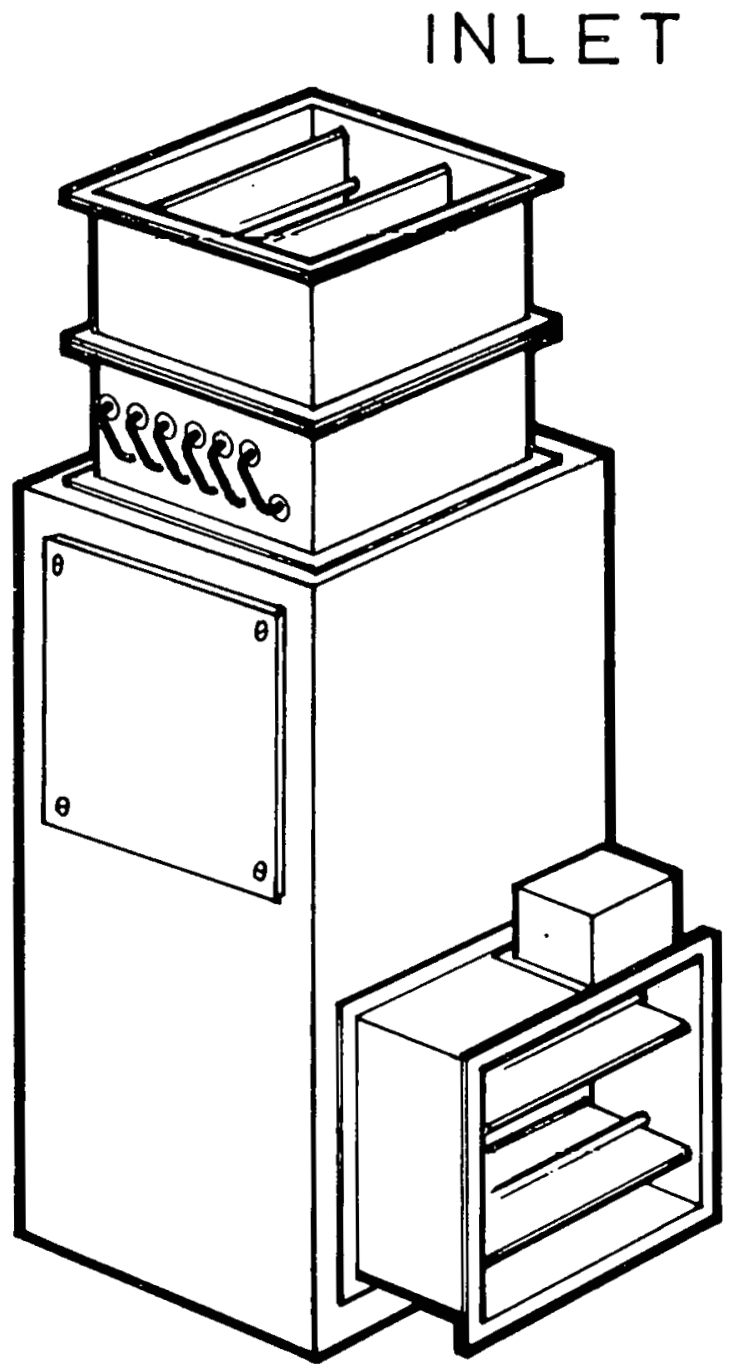

Solaron Corporation reserves the right to make changes at any time, without notice, in materials, equipment, specifications, prices, models and design criteria, and to discontinue models.
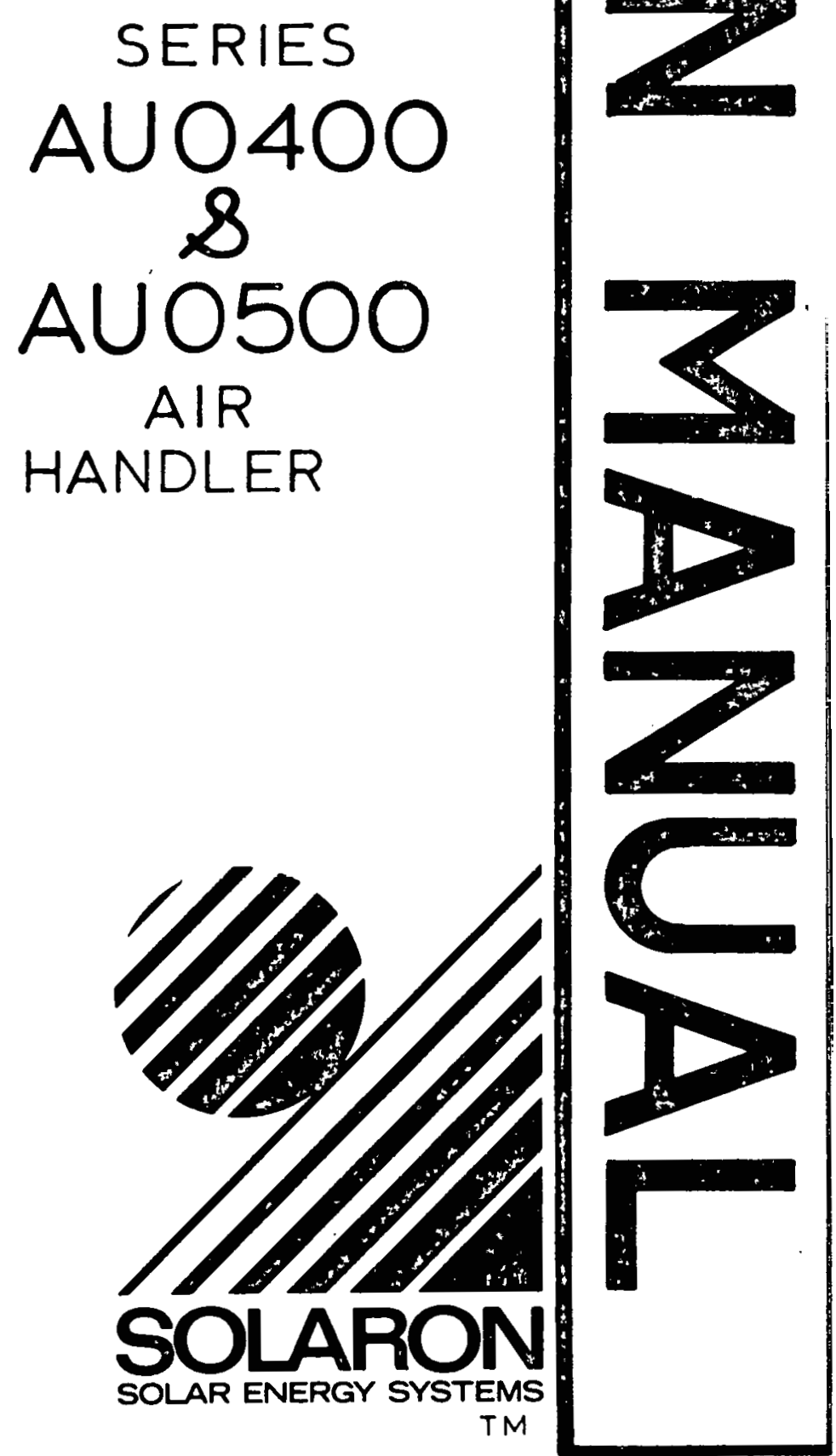

SOLARON CORPORATION ${ }^{\mathrm{TM}}$ 300 GALLERIA TOWER 720 SO. COLORADO BLVD. DENVER, CO. 80222 (303) 759-0101 
Solaron's model AU0400 series air handler units are shipped less motor and internal wiring to facilitate installation in a wide variety of applications. All AU0400 series units are manufactured with highly reliable belt drive type blowers. Motors are to be field installed to match each installations air delivery requirements. Compatible motors are $1 / 3,1 / 2 \& 3 / 4$ H.P. of 115 or 230 volt power input. Class "B" insulation types of motors are required for use in the AU0400 units due to the higher operating temperatures typical of an air-type solar heating system. All units have a factory mounted "J" box for convenient line voltage field wiring.

WARNING: Do not install the AU0400 unit in a corrosive, explosive or contaminated atmosphere for any reason. Installation of this unit is subject to all applicable local and national building codes and ordinances.

The Solaron AU0400 may be mounted in several positions. Any mounting position must result in the blower shaft being in a horizontal position (i.e. parallcl to the floor). DO NOT MOUNT in a position that places the blower shaft in a vertical orientation.

The AU0400 may be suspended from ceiling joists, wall-mounted or floor mounted. Provide adequate vibrations isolators to insure quiet operation.

NOTE: The AU0400 contains no electric heating coils or gas-fired exchangers that produce inherently high temperatures.

\section{REQUIRED DAMPER MOUNTING}

Mounting the Solaron dampers on the inlet and outlet of the AU0400 air handler is easily accomplished if the steps listed below are followed:

1. If the system incorporates the optional domestic water preheating, mount the water coil assembly to the inlet of the AUO400 unit using sheet metal screws. (If the inlet is to be on the end of the AHU, an opening must be field cut). Next, mount damper MD1 onto the mounting flange of the water coil assembly.

2. Position and mount with sheetmetal screws damper MD1 (inlet from collector "normally closed") over the opening on the inlet of the air handler, or water coil if used. Dampers are labeled to indicate direction of air flow and must be installed accordingly.

3. Position and mount with sheetmetal screws damper MD2 (outlet to auxiliary heating unit "normally open") over one of the openings on the outlet of the air handler. Field cutting may be required.

4. Position and mount the field supplied duct over one of the other openings on the outlet of the air handler going to the top of the heat storage bin.

NOTE: The damper motor must be mounted in a position that results in the output shaft of the damper/motor being in a horizontal position (i.e., damper blades must be parallel to the floor). All joints must be sealed air-tight with silicone caulking. 


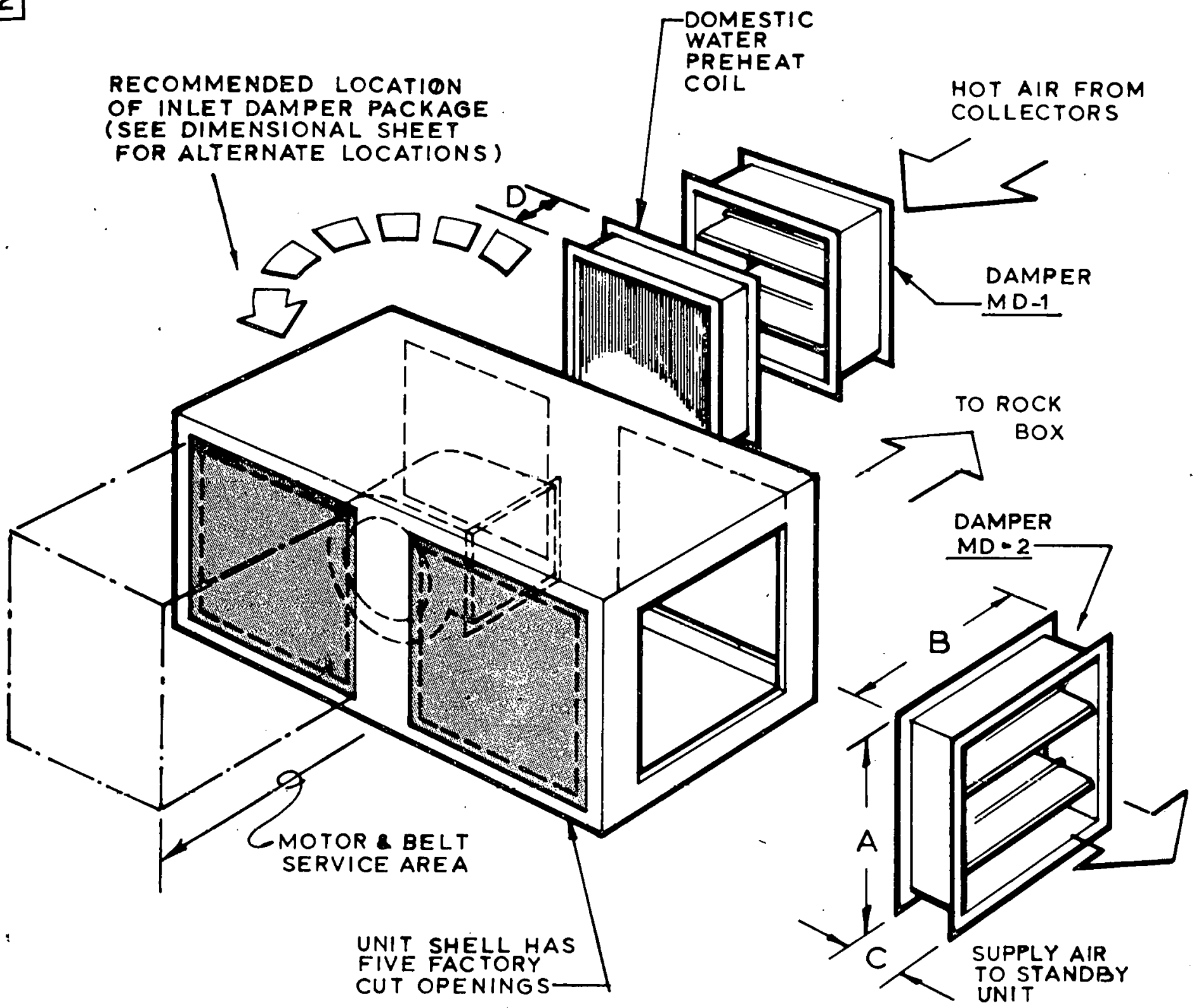

\begin{tabular}{|c|c|c|c|c|}
\hline \multirow{2}{*}{$\begin{array}{c}\text { Model } \\
\text { No. }\end{array}$} & \multicolumn{4}{|c|}{$\begin{array}{l}\text { DAMPERS DOM. } \\
\text { WATER COIL }\end{array}$} \\
\cline { 2 - 5 } & A & B & C & D \\
\hline AU-0400 & $16^{\prime \prime}$ & $16^{\prime}$ & $8^{\prime \prime}$ & $6^{\prime \prime}$ \\
\hline AU-0500 & $20^{\prime}$ & $20^{*}$ & $10^{\prime \prime}$ & $6^{\prime \prime}$ \\
\hline
\end{tabular}

TWO COVER PANELS ARE WITH UNIT. ADDITIONAL PANELS MUST BE FIELD FABRICATED.

The above drawing will furnish orientation information as well as essential dimensional data. 


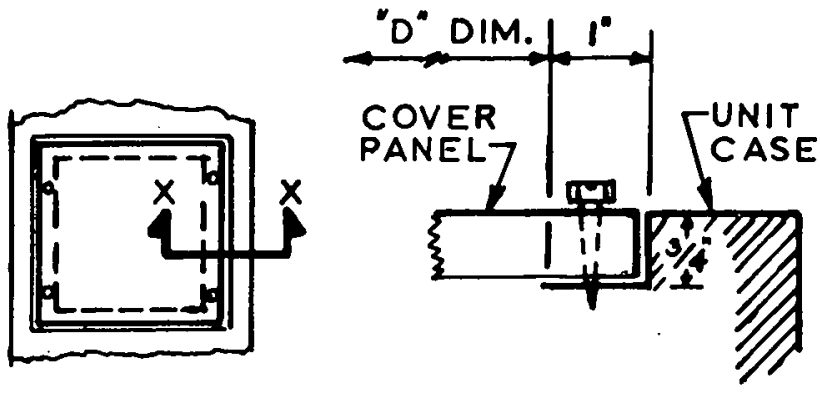

COVER PANEL SECTION $X-X$

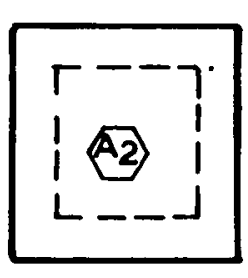

$\underline{\text { TOP }}$

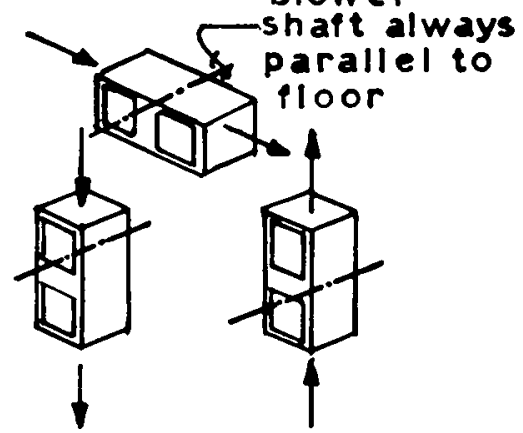

MOUNTING

\section{(2) SUPPIED}
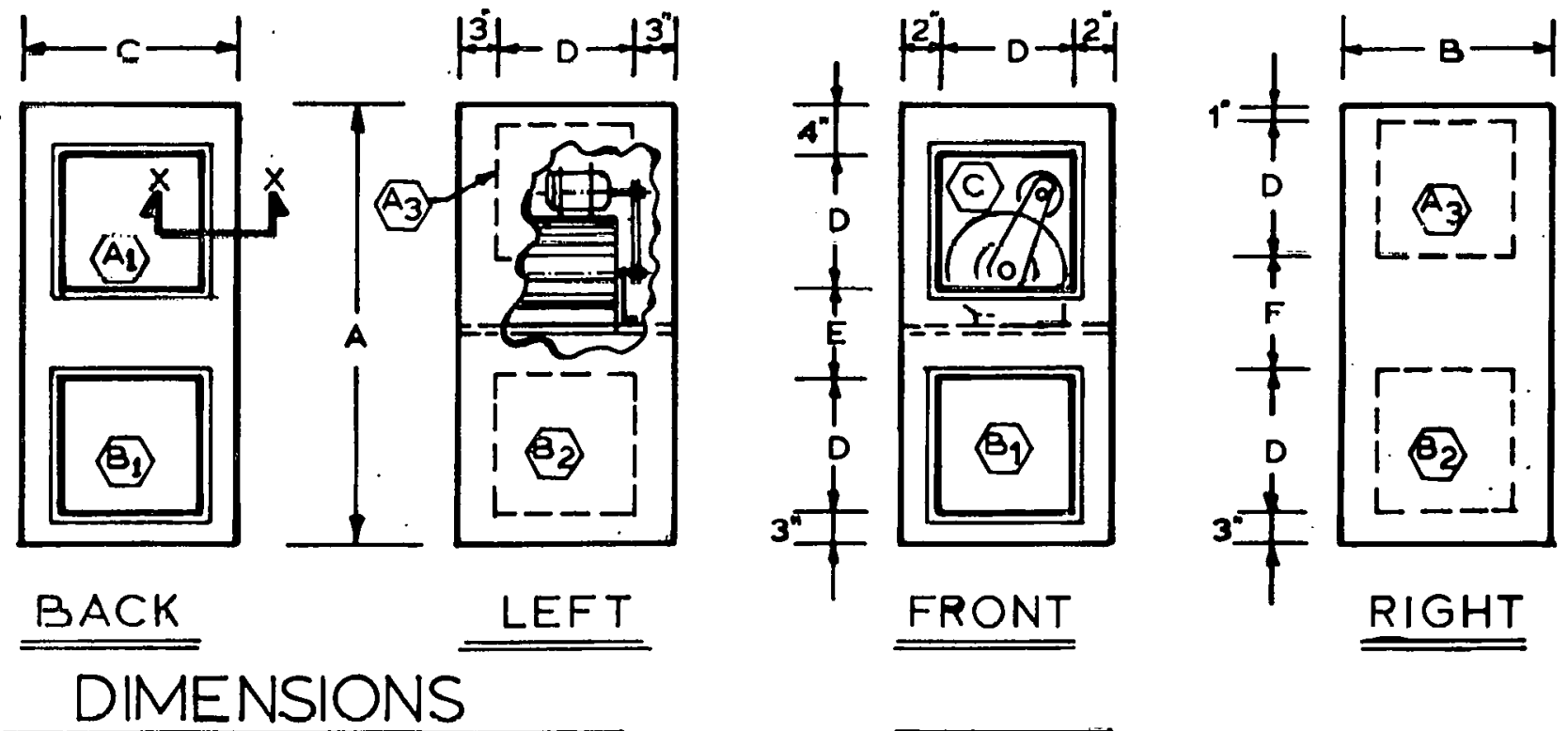

\begin{tabular}{|c||c|c|c|c|c|c|}
\hline UNIT & $A$ & $B$ & $C$ & $D$ & $E$ & $F$ \\
\hline$A U-0400$ & 42 & 20 & 18 & 14 & 7 & 10 \\
\hline$A U-0500$ & 51 & 24 & 22 & 18 & 8 & 11 \\
\hline
\end{tabular}

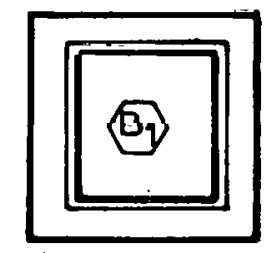

BOTTOM

NOTES

INLETS

A FACTORY CUT (DO NOT USE)

A FIELD CUT (RECOMMENDED)

A3 FIELD CUT (8\% FAN CAPACITY
REDUCTION)
OUTLETS

B1 FACTORY CUT (STANDARD)

B FIELD CUT (OPTION)

C) SERVICE ACCESS FOR MOTOR AND DRIVE REMOVAL
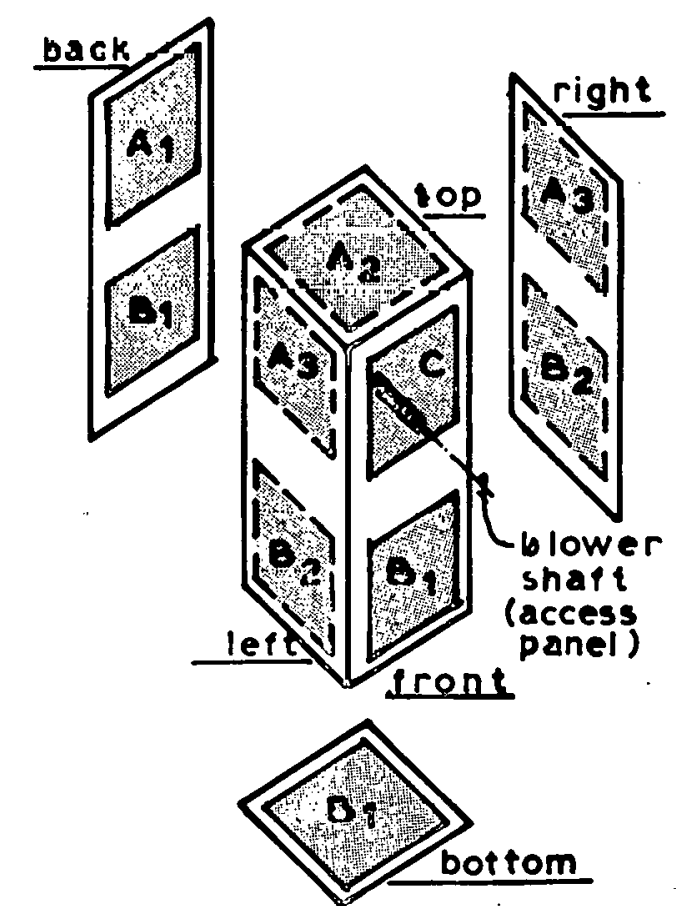

AUO400 \& AU0500 AIR HANDLING UNIT 
Locate the filter "upstrèam" of backdraft damper BD-1 (and "by-pass" duct when used).

\section{FILTERS}

The Solaron air system requires a filter in the return air duct supplying air to the inlet side of the collector and the heat storage bin. A filter is not needed in the AU0400/AU0500 unit.

Should an electronic air cleaner be desired, install it in the return air duct mentioned above. DO NOT install on the inlet of the auxiliary furnace as the air temperatures at this location may exceed the electronic air cleaner's maximum operating temperature (usual1 $125^{\circ} \mathrm{F}$ ).

\section{HUMIDIFIFRS}

Horizontally mounted type humidifiers are recommended. Locating the humidifier in a horizontal supply duct coming off of the auxiliary heating unit is ideal. Utilizing a sail-switch activated duct humidistat (similar to a Honeywell $\mathrm{H} 49 \mathrm{~B}$ ) will simplify the wiring requirements of most installations.

DO NOT wire low voltage humidifiers or air cleaner relays in series with the thermostat wires ( $W_{1}$ or $W_{2}$ ) as this can damage the Solaron controller. Sail or air pressure switches are recommended.

\section{LOCATING THE THERMOSTAT}

The Solaron multi-element thermostat should be located on an interior wall free from cold and warm drafts. Be sure adequate room air movement is present so the thermostat will provide a comfortable building temperature.

Do not locate the thermostat near lamps, heat outlets, stoves, refrigerators, television sets, etc. The heat given off by these appliances will not allow the thermostat to properly control the building temperature.

The thermostat heat anticipators should be set as follows: $W_{1} 0.10$ amp, $W_{2} @ 10 \mathrm{amp}$.

(C) copyright Solaron Corporation, Denver, Colorado 
SOLARON CONTROLLER \& THERMOSTAT LIST

AU0400 and AU0500 air handler can be used in various applications.

\begin{tabular}{|c|c|c|c|}
\hline Application & $\begin{array}{l}\text { Solaron } \\
\text { Controlier }\end{array}$ & $\begin{array}{l}\text { Thermostat \& } \\
\text { Sub-base }\end{array}$ & $\begin{array}{l}\text { Additional Relays } \\
\text { Needed }\end{array}$ \\
\hline Heating Only & $\mathrm{HCO} 0115$ & $\begin{array}{l}\mathrm{HC} 0020 \\
\mathrm{HC} 0040\end{array}$ & $\begin{array}{l}\text { (3) \#SR0225 Relays } \\
\text { 1-AU0400 Blower } \\
\text { 1-Dom. Water Pump } \\
\text { 1-Aux. Blower }\end{array}$ \\
\hline $\begin{array}{l}\text { Heating Only } \\
\text { with continuous } \\
\text { fan option }\end{array}$ & HCO115 & $\begin{array}{l}\mathrm{HC} 0020 \\
\mathrm{HC} 0041\end{array}$ & $\begin{aligned} \text { (3) \#SR0225 Relays } \\
\text { Same as Above } \\
\text { *(1) \#SR0157 Relay }\end{aligned}$ \\
\hline $\begin{array}{l}\text { Heating/cooling } \\
\text { with continuous } \\
\text { fan option }\end{array}$ & HCO115 & $\begin{array}{l}\mathrm{HCOO} 22 \\
\mathrm{HCO} 41\end{array}$ & $\begin{array}{r}\text { (3) \#SR0225 Relays } \\
\text { Same as Above } \\
\text { *(1)\#SR0157 Relay }\end{array}$ \\
\hline $\begin{array}{l}\text { Heat pump-reversing } \\
\text { valve energized } \\
\text { for heating }\end{array}$ & $\mathrm{HC} 0116$ & $\begin{array}{l}\mathrm{HCO} 022 \\
\mathrm{HCO} 042\end{array}$ & $\begin{array}{l}\text { (2)\#SR0225 Relays } \\
\text { 1-AU0400 Blower } \\
\text { 1-Dom Water Pump }\end{array}$ \\
\hline $\begin{array}{l}\text { Heat Pump-reversing } \\
\text { valve energized ... } \\
\text { for cooling }\end{array}$ & $\mathrm{HCO116}$ & $\begin{array}{l}\mathrm{HCOO23} \\
\mathrm{HCO042}\end{array}$ & $\begin{array}{c}\text { (2)\#SR0225 Relays } \\
\text { Same as Above }\end{array}$ \\
\hline
\end{tabular}

*Insert SR0157 relay into fourth base of HCO115

\section{LOCATING THE SOLARON CONTROL PANEL}

Mount the control panel in a convenient location that allows easy access for electrical wiring and "summer/winter" switch operation. Generally the mechanical room is the best location. Electrical service consisting of one $115 \mathrm{vac}$ circuit is ample to power the $100 \mathrm{VA}, 120 \mathrm{VAC} / 24$ VAC transformer accompanying the control panel. Separate power circuits may be needed for the AU0400/AU0500 unit and the auxiliary heating unit (refer to local and national building codes).

Low voltage wiring is needed to connect the Solaron space thermostat to the Solaron control panel as well as between the auxiliary heating unit, damper motors and the control panel. Damper motors are low voltage.

The thermostat MUST be wired through the Solaron control panel, it CANNOT be wired direct to the auxiliary heating unit and Solaron air handling unit.

See instructions with each controller for specific directions and information on wiring schematics. 
Sensors must be properly placed in the following locations before system start-up can be accomplished:

1. Tco - Sensor must be in absorber plate air channel (not in duct connection or manifold plenum).

2. Tci - Locate at junction of house return air duct and duct connecting to bottom of heat storage (for systems with by-pass of heat storage for summer water pre-heating, locate in duct to collector where by-pass tees in).

3. Ts - Top of rock in heat bin:

4. Tw - Locate in bottom of water storage tank (not the auxiliary water heater) near inlet of heat exchanger coil. (If using an unwired electric water heater for a storage tank, the thermostat in the tank can be used as Tw. Disconnect power leads from thermostat and. power element and wire through terminals that "open" on temperature rise).

\section{SYSTEM START-UP}

Please review all steps before proceeding with the system start up of the Solaron Air Handler AU0400/AU0500.

1. Check for proper mounting of belt-drive motor (field installed).

2. Check belt tension.

3. Check pulleys for tightness on shafts.

4. Remove all tools, materials, etc. from inside unit.

5. Check auxiliary heating unit as per manufacturers recommendations.

6. Turn on power to solar air handling unit and controller.

7. Check rotation of solar air handler blower.

8. Turn on power to auxiliary heating unit.

9. Secure all access doors.

10. Check operation of all components and systems as per Solaron control instructions.

11. Give the system owner instructions on how to operate their new Solaron solar system. 


\section{BLOWER MOTOR AND DRIVE ASSEMBLY SELECTION PROCECURE}

1. Refer to building plans for air flow and static pressure requirements. Include pressure drop of all dampers and coils in system. (See Selection Example this Manual Pg. 10.)

2. Refer to the Air Delivery Table for each respective air hardler:

a. select the row which indicates that static pressure recuired, and

b. select the column which shows the CFM required.

The point where the row and column intersect will indicate what blower RPM and H.P. motor are needed to deliver the required air flow.

AU0400 AIR DELIVERY TABLE

\begin{tabular}{|c|c|c|c|c|c|c|c|c|c|c|c|c|c|}
\hline \multirow{3}{*}{$\begin{array}{l}\text { "W.C." } \\
\text { Ext. Static } \\
\text { Pressure }\end{array}$} & \multicolumn{12}{|c|}{ CFM } & 1 \\
\hline & \multicolumn{5}{|c|}{ 1/4 H.P. } & \multicolumn{4}{|c|}{$1 / 3$ H.P. } & \multicolumn{2}{|c|}{ 1/2 H.P. } & \multirow{2}{*}{$\frac{3 / 4 \mathrm{HP}}{1400}$} & \\
\hline & 300 & 400 & 500 & 600 & 700 & 800 & 900 & 1000 & 1100 & 1200 & 1300 & & \\
\hline .6 & - & - & - & $=$ & $=$ & - & - & $=$ & - & 1055 & 1120 & 1150 & \\
\hline .8 & 1038 & 1041 & 1045 & 1045 & 1048 & 1058 & 1060 & 1092 & 1120 & 1156 & 1187 & 1235 & \\
\hline 1.0 & 1185 & 1190 & 1157 & 1158 & 158 & 1159 & 1160 & 1190 & 1220 & 1245 & 1280 & 1310 & RPM \\
\hline 1.2 & 1300 & 1300 & 1295 & 1279 & -265 & 1260 & 1270 & 1290 & 1310 & 1335 & 1360 & 1389 & \\
\hline 1.4 & - & 1422 & 1405 & 1385 & $: 375$ & 1370 & 1370 & 1375 & 1400 & $14 \check{\measuredangle} 0$ & 1455 & - & \\
\hline
\end{tabular}

AU0500 AIR DELIVERY TABLE

\begin{tabular}{|c|c|c|c|c|c|c|c|c|c|c|c|c|c|c|c|}
\hline \multirow{3}{*}{$\begin{array}{l}\text { "W.C" } \\
\text { Ext. Static } \\
\text { Pressure }\end{array}$} & \multicolumn{15}{|c|}{ CFM } \\
\hline & \multicolumn{7}{|c|}{$3 / 4$ H.P. } & \multicolumn{4}{|c|}{1 H.P. } & \multicolumn{4}{|c|}{$1-1 / 2$ H.P. } \\
\hline & 1200 & 1300 & 1400 & 1500 & 1600 & 1700 & 1800 & 1900 & 2000 & 2100 & 2200 & 2300 & 2400 & 2500 & 2600 \\
\hline .8 & - & - & - & - & - & - & 1000 & 1021 & 1040 & 1064 & -088 & 1116 & 1143 & 1171 & 1200 \\
\hline 1.0 & 1028 & 1032 & 1041 & 1043 & 1053 & 1064 & 1078 & 1093 & 1111 & 1132 & $\mathbf{I} 155$ & 1181 & 1205 & 1234 & 1266 \\
\hline 1.2 & 1121 & 1122 & 1124 & 1127 & 1135 & 1143 & 1154 & 1167 & 1182 & 1200 & 1223 & 1248 & 1274 & 1307 & \\
\hline 1.4 & 1213 & 1212 & 1211 & 1213 & 1213 & 1220 & 1229 & 1240 & $125 j$ & 1273 & 1295 & 1318 & 1343 & & \\
\hline 1.6 & 1301 & 1295 & 1290 & 1280 & 1288 & 1292 & 1304 & 1313 & 1327 & 1345 & I366 & 1388 & & & \\
\hline 1.8 & 1383 & 1376 & 1367 & 1363 & 1363 & 1365 & 1376 & 1387 & 1400 & 1417 & & & & & \\
\hline
\end{tabular}


Since the RPM is now known, merely refer to the Drive Assembly Table. Select the RPM needed in the left-hand column. To the right of the RPM column are other columns indicating the number of turns open a specific driver pulley must be in order to deliver that particular RPM. Select whichever column gives the RPM desired. The driven pully, or fixed blower pulley, is selected from the extreme right hand column. $V$-belts are noted under each "Driver" column. To determine bore sizes of driver pulleys refer to the Blower Motor Chart for shaft dimensions. Bore size for all fixed pulleys is 3/4" for the AU0400 and 1" for the AU0500.

AU0400 DRIVE ASSEMBLY TABLE

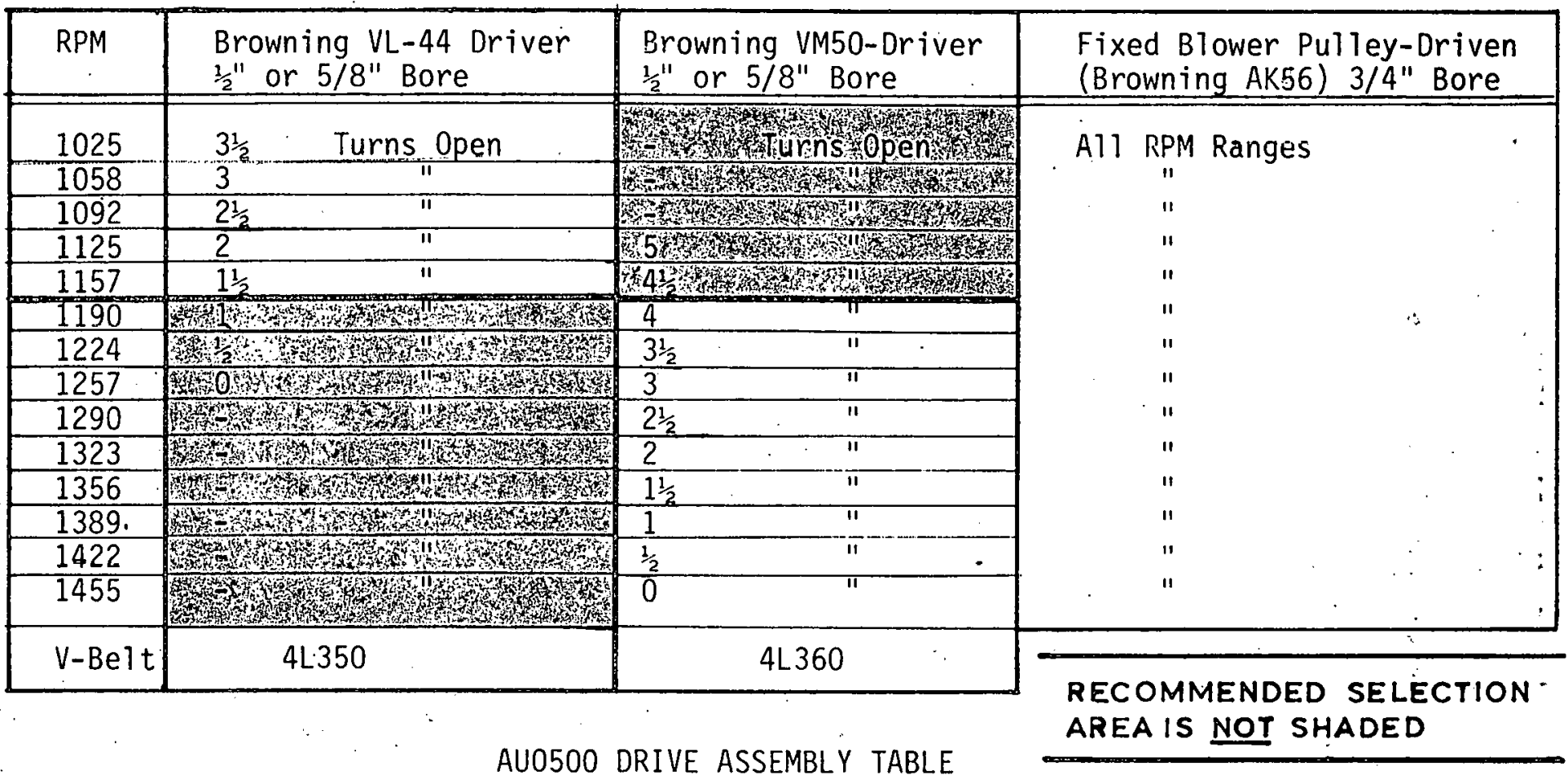

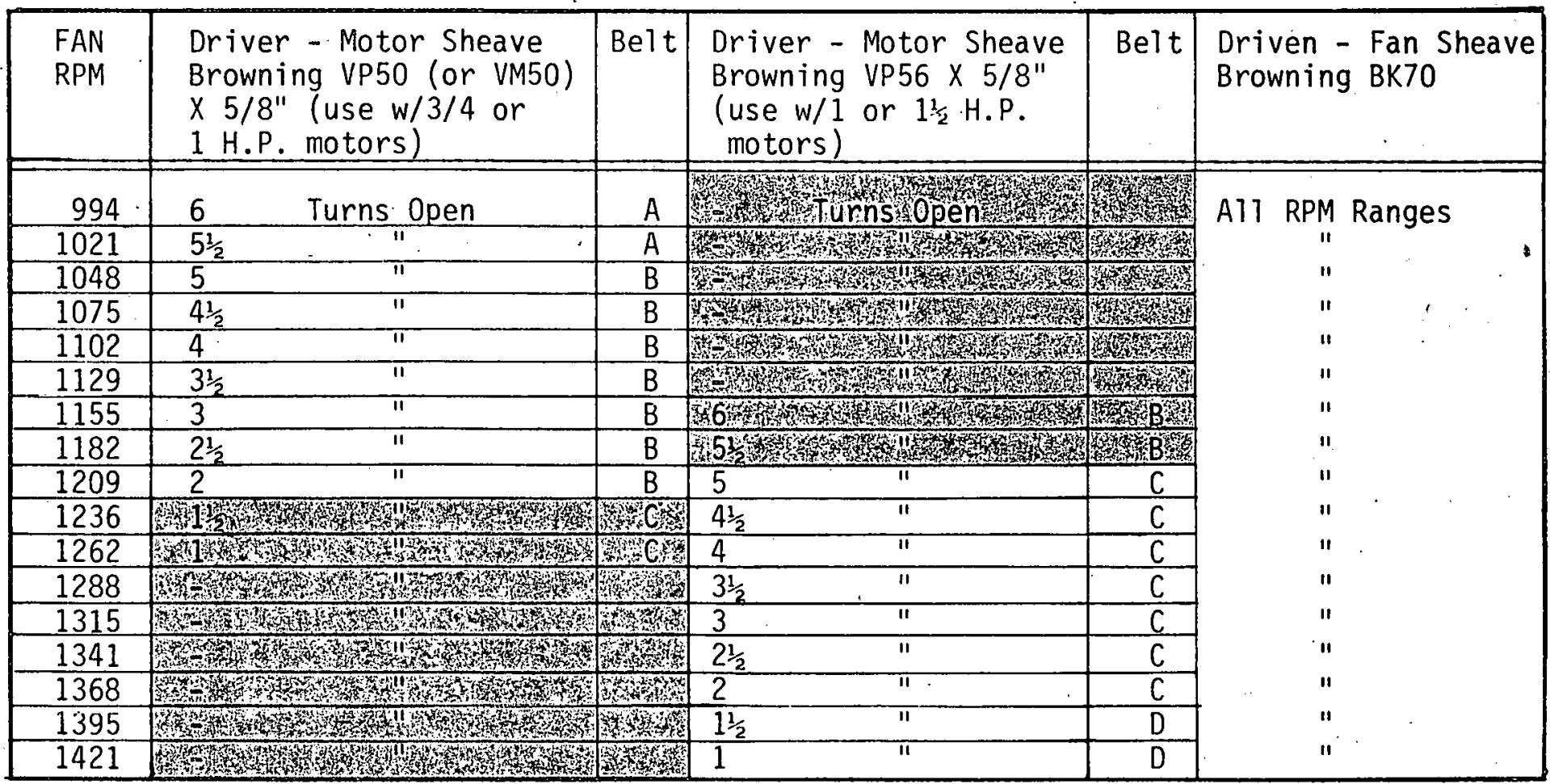
(C)
copyright 1977 


\begin{tabular}{|c|c|c|c|}
\hline \multicolumn{3}{|c|}{ V-BELTS FOR AU0500 } \\
\hline \hline V-Belts & A & $5 L 420$ & Type V-Belts \\
\hline & B & $5 L 430$ & Type V-Belts \\
\hline & C & $5 L 440$ & Type V-Belts \\
\hline & D & $5 L 450$ & Type V-Belts \\
\hline
\end{tabular}

AU0400 AND AU0500 BLOWER MOTORS

\begin{tabular}{|c|c|c|c|c|c|c|}
\hline H.P. & $\begin{array}{l}\text { Serv. } \\
\text { Factor* }\end{array}$ & $\begin{array}{l}\text { NEMA } \\
\text { Frame }\end{array}$ & $\begin{array}{l}\text { Shaft } \\
\text { Dia. \& Len. }\end{array}$ & $\begin{array}{l}\text { F.L.A. } \\
115 \mathrm{~V}\end{array}$ & $\begin{array}{l}\text { G.E. } \\
\text { Model }\end{array}$ & Shpg. Wt. \\
\hline \multicolumn{7}{|c|}{ Split Phase Motors - 1725 RPM 115/230V - $60 \mathrm{HZ}-10$ (Class A) } \\
\hline $1 / 4$ & 1.35 & $48 z$ & $\frac{1}{2}{ }^{11} \times 22^{111}$ & 5.2 & $5 K H 33$ FN15T** & 15 lbs. \\
\hline $1 / 3$ & 1.35 & $56 z$ & $\frac{1}{2}=22^{111}$ & 6.0 & $5 \mathrm{KH} 35 \mathrm{JN} 30 \mathrm{~T}^{\star \star}$ & $181 \mathrm{bs}$. \\
\hline $1 / 2$ & 1.25 & $56 z$ & $\frac{1,11}{2} \times 2 \frac{1}{4}{ }^{11}$ & 9.0 & $5 \mathrm{KH} 36 \mathrm{MN} 22 \mathrm{T* \star}$ & 23 lbs. \\
\hline \multicolumn{7}{|c|}{ Capacitor -Start Moțors - 1725 RPM 115/230 - $60 \mathrm{HZ}-1 \emptyset$ (Class B) } \\
\hline $3 / 4$ & 1.25 & $56 z$ & $5 / 8^{11} \times 2 \frac{1}{4} 11$ & 11.6 & 5KC39UN7T** & $301 \mathrm{bs}$. \\
\hline 1 & 1.25 & $56 z$ & $5 / 8^{11} \times 21_{4}^{11}$ & 14.6 & 5KC48TG726T** & 35 lbs. \\
\hline $1-1 / 2$ & 1.15 & 56 & $5 / 8^{\prime \prime} \times 1-7 / 16^{11}$ & 21.0 & $6 \mathrm{~K} 324$ & 39 Tbs. \\
\hline
\end{tabular}

The above General Electric "Serv-S-Line" or Dayton motors are 1725 RPM, $115 / 230$ Volt, $60 \mathrm{~Hz}, 1$ phase, automatic reset, thermally protected types recognized by UL under the Motor Component Recognition Program. These motors are open, drip-proof type motors with Class "A" or "B" insulation, ball bearings, resilient base. The motor rotation can be reversed by reconnecting various electrical leads within the motor.

* Motors operated on 200 volts, $60 \mathrm{~Hz}$ will have a 1.0 service factor.

** Manufacturers producing motors of equal specification may be used. CLASS B MOTORS ARE RECOMMENDED FOR REPLACEMENT. 
10 Selection Example:

Given: $312 \mathrm{ft}^{2}$ solar sollector area (i.e. 2 high, 8 wide, vertical)

Solution: Air handler flow rate $\left(2 \mathrm{CFM} / \mathrm{ft}^{2}\right)(312=624 \mathrm{CFM}$, round up to $625 \mathrm{CFM}$

The air handler motor and drive assembly must be selected to handle the external static pressure on the Solaron air handler. This selection should be based on the mode which has the highest static pressure drop. The possible modes are:

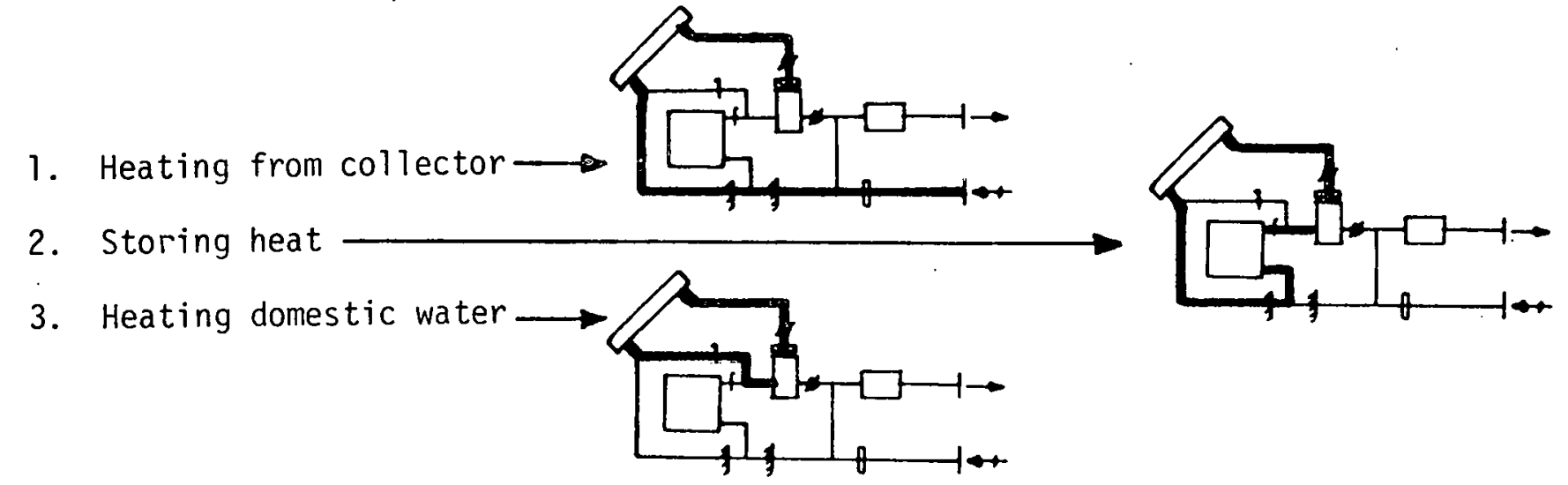

The highest pressure drop for this example is \#i, heating from collectors.

The external static pressure drop for this is:

Return grille (see mfg. data)

Returnair filter (sized 0300 to $350 \mathrm{FPM}$ ) (see mfg. data)
Backdraft dampers ( 2 each) (see A\&E Manual pg. 89)
Collectors (2 pane1s in series, 2 CFIM/ft ${ }^{2}$ ) (see A\&E Manual
Domestic water coil (see this Manual, pg. 11)
*Ductwork (see below)
External Static. Pressure
Motor: 625 CFM and $1.0 "$ external static pressure
RPM would be 1158 (see AU0400 Air Delivery Table)
This falls in the region for the $1 / 2 \mathrm{H.P}$. motor.

Drive Assembly: 1158 RPM is required at the 700 CFM point. Select

1157 RPM for the 625 CFM requirement. This RPM would be obtained with the driver: Browning VL-44 set at $1-1 / 2$ turns open.

Blower fulley: Would be Browning AK-56.

Summary: 625 CFM at 1.0" external static pressure

$1 / 2$ H.P. motor Solaron \#MT0050

Driver VL-44

Pul ley AK-56

$V$-Belt 4 L 350

Solaron \#DRO120

Solaron \#DRO120) Package

Solaron \#DR0120.

$0.05^{\prime \prime}$ w.g.

0.25

0.20

0.23

0.08

0.19

$\underline{1.00^{\prime \prime} \text { w.g. }}$

*Ductwork: Static pressure drop through the ductwork is determined by the length and number of fittings. Solaron recommends that ductwork be sized at 0.08 " w.g. pressure drop per $100 \mathrm{ft}$ of duct. Fittings and elbows can be estimated by using $15 \mathrm{ft}$ equivalent length of duct for each elbow with turning vanes.

The example above was based on:

$$
\begin{aligned}
& \left.\begin{array}{ll}
(10 \text { elbows })\left(15^{\prime} \text { elbow }\right)= & 150^{\prime} \\
\text { Length of ductwork } & =\frac{90^{\prime}}{240^{\prime}} \\
\text { Total equivalent length } & \\
(240 \mathrm{ft})\left(\frac{0.08 "}{100} \mathrm{ft}\right.
\end{array}\right)=0.192 \begin{array}{l}
\text { w.g. pressure drop } \\
\text { in ductwork }
\end{array}
\end{aligned}
$$


The Solaron domestic water coil is a 1-row copper tube coil.

Calculated coil capacities for size and CFM as listed: 1/2" tube, 10

FPI, one $1 / 2^{\prime \prime}$ inlet and one $1 / 2^{\prime \prime}$ outlet, aluminum fin stock.0055, copger tube .017", capacities based on $3 \mathrm{GPM}$, ENT. water $50^{\circ}$, E.A.T. $180^{\circ} \mathrm{F}$.

\begin{tabular}{|c|c|c|c|c|c|c|c|}
\hline $\begin{array}{l}\text { AIR } \\
\text { HANDLER }\end{array}$ & SIZE & CFM & $\begin{array}{l}\text { FACE } \\
\text { VELOCITY }\end{array}$ & $\begin{array}{l}\text { WATER } \\
\text { P.D. FT. } \\
\text { O } 3 \text { GPM }\end{array}$ & LV.W. & LV.A & BTU/HR. \\
\hline \multirow[t]{3}{*}{ AU0400 } & \multirow{3}{*}{$133 / 4 \times 14$} & 600 & 447 & 8.20 & 64.7 & 146.3 & 22,050 \\
\hline & & 800 & 597 & 8.20 & 67.0 & 150.7 & 25,500 \\
\hline & & 1000 & 746 & 8.20 & 69.1 & 153.7 & 28,650 \\
\hline \multirow[t]{2}{*}{ AUOS00 } & \multirow[b]{2}{*}{$171 / 2 \times 18$} & 1100 & 642 & 13.40 & 80.7 & 151.7 & 46,050 \\
\hline & & 1700 & 780 & 13.40 & 83.9 & 152.6 & 50,700 \\
\hline
\end{tabular}

NOTE: MINIMUM WATER FLOW IS 1.5 GPM

The Solaron domestic water heating option is designed to be used with pump \#WP3060 (115/60/-Ø--.- .85 amp).

AU0400 - OPTIONAL DOMESTIC WATER HEATING COIL - PRESSURE DROP

\begin{tabular}{|c|r|r|r|r|r|r|r|r|r|r|r|r|}
\hline \hline CFM & 300 & 400 & 500 & 600 & 700 & 800 & 900 & 1000 & 1100 & 1200 & 1300 & 1400 \\
\hline Pres. Drop & .02 & .03 & .04 & .05 & .06 & .08 & .09 & .11 & .14 & .17 & .21 & .25 \\
\hline
\end{tabular}

Au0500 -

\begin{tabular}{|c|r|r|r|r|r|r|r|r|r|r|l|}
\hline \hline CFM & 1200 & 1500 & 1700 & 1900 & 2100 & 2300 & 2500 & & & & \\
\hline Pres. Drop & .08 & .09 & .11 & .14 & .17 & .25 & .33 & & & & \\
\hline
\end{tabular}

(C) copyright 42 . Solaron Corporation, Denver, Colorado 


\section{GENERAL OPERATING PROCEDURE}

FOR THE SYSTEM OWNER

\section{SOLARON AU0400 AND AU0500 AIR HANDLERS}

By simply adjusting the wall mounted thermostat you will be able to maintain a comfortably living or working environment.

By setting the switches located directly under the thermostat, and the sliding levers on top, you can select the type of operation you desire.

For winter heating set the top lever at the desired temperature that you wish to maintain. The thermostat will automatically operate the solar portion of your heating system as well as the auxiliary heating unit if conditions warrant its operation. Please do not "jiggle" the levers.

Should your space conditioning system feature cooling as well as heating, you merely move the switch underneath the thermostat to any desired position ("System Switch - Off - Heat - Auto - Coul). Locating the switch in the "Auto" position will permit the thermostat to automatically place the system in a heating or cooling mode of operation without further adjustment.

Space conditioning systems incorporating a heat pump heating and cooling auxiliary unit will have a thermostat switch position marked "Emerg. Heat". The only function of this switch is to provide emergency electric heat should the heat pump malfunction during a period of time when a serviceman is not readily available.

Nominal maintenance is required with this sytem. Please refer to "Maintenance Instructions" provided in the Installation Manual.

please call your qualified Solaron serviceman should problems develop. Installing Solaron Solar System Contractor

Name:

Address:

Phone:

The Solaron controller requires that its "Summer-Winter" switch be placed in the appropriate season position. When switching seasons it may be necessary to move some system dampers. Please have your installing contractor indicate these dampers to you.

\section{Maintenance Instruction}

The AU0400 and AU0500 require minimal upkeep for economical and long. lasting operation.

Blower Type 1 - Permanently sealed bearings - no oil required.

Motor Type 2 - Blower Motor - 0i] twice a year (\#20 S.A.E. nondetergent oil).

Blower bearings - Permanently sealed - no oiling required.

$V$-Belt - Check wear and tension, replace if necessary.

Damper Motors - $0 i 1$ with \#10 S.A.E. non-detergent oil (similar to \#465 Anderol or Goodlight \#10 0il.) Twice a year.

Water Pump - The Grundfos circulator pump requires no oiling as it is water lubricated during normal operation. 
HEAT STORAGE INSTALLATION MANUAL 


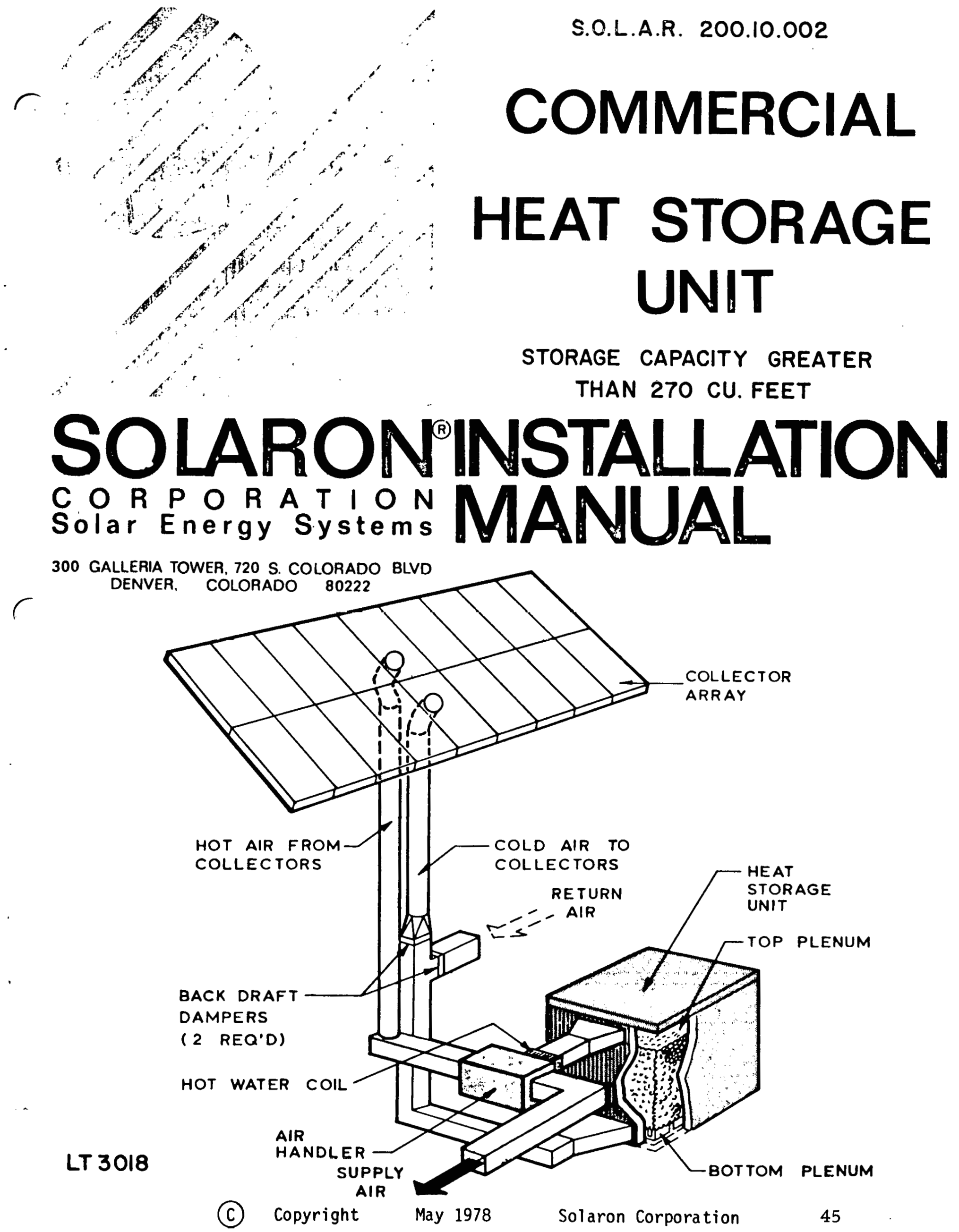




\section{THIS MANUAL IS INTENDED TO BE USED ON PROJECTS WITH A MINIMUM COLLECTOR AREA OF 540 SAULARE FEET.}

TO THE READER:

THIS MANUAL IS INTENDED TO BE A GENERAL GUIIIE FUR SIZING AND BUILDING THE HEAT STORAGE UNIT FOR A SOLARON SOI_AR HEATING SYSTEM. THE STORAGE UNIT FOR SPECIFIC PROIECTS SHOULD BE CHECKED TO ENSURE IT IS DESIGNED AND BUILT PROPERLY TO ACCOUNT FOR ALL THE VARIABLES INVOLVED.

The drawings, illustrations and text contained in this manuar are protected by copyright. Publication, reproduction, or use of all or any part of this manual (except for actual construction and de-. sign use with Solaron systems engineering plans) without special written permission from Solaron Corporation, is prohibited.

Due to our policy of continual improvement to our products, Solaron reserves the right to change the materials, installation procedures and specifications without notice.

Solaron assumes no responsibility for improperly designed or constructed heat storage units where this manual is used as a quide. 
Solaron Corporation

300 Galleria Tower

$720 \mathrm{~s}$. Colorado Blvd.

Denver, Colorado 80222

Re: Solaron Installation Manual Commercial Heat Storage Unit

Gentlemen:

Structural details and specifications contained in this manual are derived from engineering analysis and design calculations done by KKBNA, Consulting Engineers. These calculations are based on strength of materials and performance criteria in accordance with latest design standards and specifications.

The structural drawings, material and installation specifications in this manual have been reviewed to check their conformance to the design calculations.

Sincerely,

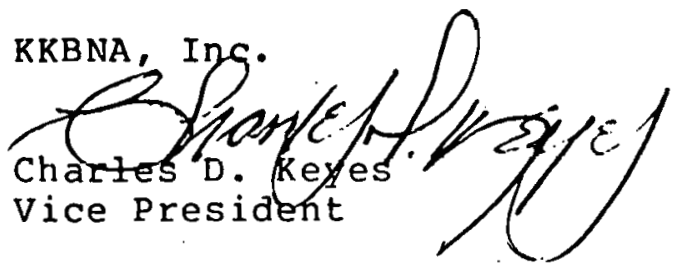

CDK : et

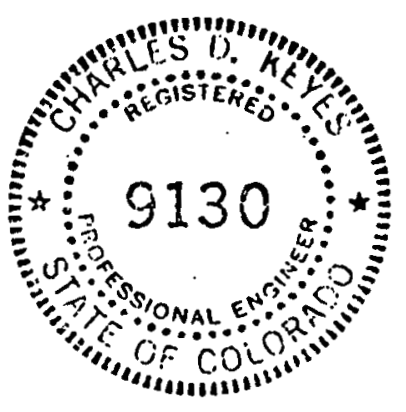




\section{TABLE OF CONTENTS}

DESCRIPTION

PAGES

GENERAI NOTFS

49

HEAT STOR

60

52

HEAT STORAGE UNIT - CONCRETE CONSTRUCTION

54

HEAT STORAGE UNIT - WOOD CONSTRIUCTION

56

HEAT STORAGE UNIT - ATTACIMENT DETAILS

59

OPTIONAL AIR HANDLER AND DUCT LOCATIONS

METAL LATH SAMPLE

60

BOND BEAM BLOCK AND TRANSITE DUCT DETAILS

61

ROCK AND SIZING METHOD

62

HEAT STORAGE UNIT CONSTRUCTION CHECKLIST .

63

64

(C) Copyright May 1978 Solaron Corporation 
The use of pebbles in the heat storage unit is particularly effective with an air circulating solar heating system. The pebble bed maintains a high degree of temperature stratification (i.e., hot on top and cold on the bottom). This allows air to be provided at the highest available temperature to the heated space from the top of the pebble bed. It also allows air to return from the bottom of the bed to the collector at essentially room temperature, thus maximizing efficiency of solar heat collection and delivery.

The heat storage container can be constructed of any of the following materials:

a. Poured, reinforced concrete with a rigid fiberglass insulation inner liner (i.e., insulation is inside, separating the rock from the concrete wall).

b. Wood frame, plywood on $2 \times 4$ or $2 \times 6$ studs with a non-combustible inner liner suitable for temperatures as high as $200^{\circ} \mathrm{F}$.

The heat storage unit should be built and installed by the local contractor to Solaron standard drawings and specifications. The air flow through the pebble bed must be vertical. Horizontal flow in pebble beds must be avoided due to channeling and "hot spot" problems.

It is important that the heat storage container be airtight and insulated as follows:
a. Storage unit inside a heated space: $R-11$ minimum.
b. Storage unit inside an unheated space: R-30 minimum.
c. Storage unit inside a heated space with wall in unheated area: $\mathrm{R}-30$ minimum.

The heat storage unit can be conveniently placed in the basement or crawl spac or set into the ground. Buried heat storage units must be waterproofed on all buried external surfaces (do not use asphalt or other sealers on inside walls) DO NOT bury heat storage unit below the high ground-water level due to possibility of water leakage into heat storage unit and resulting loss of performal Support footings must be designed for local soil conditions. Due to the weig of the rocks, it should not be placed in the attic or on the upper floors wit out proper structural support. Typical floor loading with a rock depth of 5 feet is 500 pounds per square foot of floor area.

\section{Design Criteria}

Rock: - Hard dense rock (i.e., density $=100 \mathrm{lbs} . / \mathrm{ft}^{3}{ }^{3}$, or greater).

- River gravel or hard, dense crushed rock is OK.

- Uniform size (i.e., most systems will use rock sized at $3 / 4$ " to $1-1 / 2^{\prime \prime}$ in diameter).

- Clean the rock before is is loaded in the storage box (i.e., wash it).

- Minimum of fines (i.e., 0 to $5 \%$ ).

Storage: - Airtight, insulated, structurally sound and, if buried, externally waterproofed. The inside surface materials must be able to withstand temperatures of approximately $200^{\circ} \mathrm{F}$.
(C) Copyright
May 1978
Solaron Corporation 
GENERAL NOTES

1. ANY SUBSTITUTION OF MATERIALS, CHANGES OF DIMENSIONS OR OTHER CHANGES IN HEAT STORAGE UNIT AS SHOWN MUST BE APPROVED BY SOLARON CORPORATION IN WRITING PRIOR TO START OF CONSTRUCTION.

2. ALL FOOTING AND STRUCTURAL SUPPORTS ARE THE RESPONSIBILITY OF OWNER AND/ OR ARCHITECT AND SHALL BE SIZED ACCORDING TO SOIL REPORT INFORMATION. COORDINATE THIS DRAWING WITH ARCHITECTURAL DRAWINGS FOR TYPE, SIZE AND LOCATION OF FOOTING AND STRUCTURAL SUPPORTS.

3. JOINTS, CRACKS, SEAMS AND PENETRATIONS INSIDE AND OUT IN WALLS, FLOOR AND LID OF HEAT STORAGE UNIT SHALL BE SEALED AIR-TIGHT WITH DOW CORNING \#732 SILICONE SEALANT CAULK OR APPROVED EQUAL.

4. BOND BEAM BLOCK - 2 OR 3 WEB. WEBS MUST BE AT A. RIGHT ANGLE TO WALL CONTAINING BOTTOM OPENING (SEE DETAIL FOR TRANSITE DUCT AND BOND BEAM BLOCK ORIENTATION).

5. METAL LATH - USE JR. DIAMOND MESH 3.4 LB./SQ. YD. (GALVANIZED) ADJOINING PIECES TO BE OVERLAPPED A MINIMUM OF 6". TURN EDGE UP ONTO INNER WALLS OF HEAT STORAGE UNIT A MINIMUM OF 12".

6. THE ROCK SHALL BE ROUND WASHED RIVER ROCK OR STONE. 95\% OF THE ROCK. SHALL BE THE SIZE SHOWN ON THE PLANS WITH A MINIMUM AMOUNT OF FINES (I:E., LESS THAN $1 / 4 "$ DIAMETER). THE ROCK SHALL BE CLEAN AND FREE OF DIRT. NORMALLY THE ROCK IS SIZED BY SCREENING (THAT ROCK WHICH PASSES THROUGH A 1-1/2" SCREEN BUT NOT A 3/4" SCREEN IS THE NORMAL SIZE).

7. TREATMENT FOR THE INSIDE SURFACES OF THE BOX SHALL BE SUITABLE FOR TEMPERATURES OF $200^{\circ} \mathrm{F}$. NO COMBUSTIBLE MATERIAL WILL BE USED.

8. NON-LOAD BEARING LID SHALL BE CONSTRUCTED OF $1 / 2 "$ EXTERIOR GRADE PLYWOOD INSIDE AND OUT--2 $\times$ 4'S - 24" ON CENTER AND 1/2" MOISTURE-RESISTANT TYPE " $X "$ DRYWALL ON INSIDE SURFACE TOWARD PEBBLES. 28-GAUGE SHEET METAL CAN BE USED IN LIEU OF DRYWALL.

9. LOAD BEARING LID SHALL BE CONSTRUCTED OF $1 / 2^{\prime \prime}$ EXTERIOR GRADE PLYWOOD INSIDE AND OUT--2 $\times 6^{\prime} \mathrm{S}-24^{\prime \prime}$ ON CENTER AND $1 / 2^{\prime \prime}$ MOISTURE-RESISTANT TYPE " $X "$ DRYWALL ON INSIDE SURFACE TOWARD PEBBLES. 28-GAUGE SHEET METAL CAN BE USED IN LIEU OF DRYWALL.

\begin{tabular}{|l|l|l|}
\hline \multicolumn{3}{|c|}{ HEAT STORAGE UNIT DESIGN PARAMETERS } \\
\hline $\begin{array}{c}\text { DESIGN TEMPERATURE } \\
\text { TOP AND BOTTOM }\end{array}$ & \multicolumn{1}{|c|}{ PRESSURES } & \multicolumn{1}{c|}{ AIR FLOW } \\
\hline $\begin{array}{l}\text { MAXIMUM TEMPERATURE } \\
\left(200^{\circ} \mathrm{F}\right)\end{array}$ & ENTIRE STORAGE UNIT & $\begin{array}{l}\text { THRU ROCK } 20 \text { TO } 40 \\
\text { FPM }\end{array}$ \\
\hline $\begin{array}{l}\text { OPERATING RANGE } \\
\left(90^{\circ} \text { TO } 180^{\circ}\right)\end{array}$ & $\begin{array}{l}\text { ATMOSPHERIC PRESSURE } \\
\pm 3^{\prime \prime} \text { W. C. }\end{array}$ & $\begin{array}{l}\text { THRU OPENINGS } 800 \\
\text { TO 1000 FPM }\end{array}$ \\
\hline $\begin{array}{l}\text { MINIMUM TEMPERATURE } \\
\text { (AMBIENT) }\end{array}$ & $\cdots$ & \\
\hline
\end{tabular}

(C) Copyright May 1978 Solaron Corporation 


\section{GENERAL NOTES}

(continued)

9. CONCRETE:

A. ALL CONCRETE SHALL ATTAIN 3,000 PSI ULTIMATE COMPRESSIVE STRENGTH IN 28 DAYS.

B. ALL REINFORCING SHALL BE HIGH STRENGTH DEFORMED BARS ASTM DESIGNATION A615, GRADE 40 OR GRADE 60.

10. STEEL:

ALL STRUCTURAL STEEL SHALL CONFORM TO ASTM SPECIFICATION A36.

11. MASONRY:

A. ALL MORTAR SHALL DEVELOP 1,800 PSI ULTIMATE COMPRESSIVE STRENGTH IN 28 DAYS.

B. ALL MASONRY SHALL DEVELOP 1,500 PSI ULTIMATE COMPRESSIVE STRENGTH IN 28 DAYS.

C. ALL REINFORCING SHALL CONFORM TO ASTM 615, GRADE 40 OR GRADE 60.

12. WOOD:

A. ALL FRAMING LUMBER SHALL BE DRY HEM-FIR GRADE 2.

B. ALL PLYWOOD SHALL BE OF THICKNESS SPECIFIED C-C EXT OFPA OR BETTER. NAILED TO SUPPORTS WITH 10d NAILS SPACED 6" 0.C. AT PANE! EDGES AND SPACED 12" 0 .C. AT ALL OTHER SUPPORTS. PLYWOOD SHALL BE APPLIED WITH FACE GRAIN PERPENDICULAR TO SUPPORTS.

13. TRANSITE DUCT:

TRANSITE DUCT CAN BE USED INSTEAD OF THE EXTERNAL BOTTOM DUCT OPENING TO ALLOW AIR FLOW TO AND FROM THE BOTTOM OF THE HEAT STORAGE UNIT WITHOUT PENETRATING THE UNIT OR RUNNING AN EXTERNAL DUCT. EXAMPLE: WHEN MECHANICAL EQUIPMENT IS INSTALLED ON TOP OF THE HEAT STORAGE UNIT. OR WHEN THE HEAT STORAGE UNIT IS BURIED.

ONE 16" DIAMETER DUCT SERVES $270 \mathrm{CU}$. FT. OF STORAGE AT 1,080 CFM.

TWO 16" DIAMETER DUCTS SERVE $540 \mathrm{CU}$. FT. OF STORAGE AT 2,160 CFM.

THREE 16" DIAMETER DUCTS SERVE $810 \mathrm{CU}$. FT. OF STORAGE AT 3,240 CFM.

(C) Copyright May 1978 Solaron Corporation 
a. VOLUME: Storage size is determined from the collector area. $1 / 2$ " $\mathrm{ft}^{3}$ to $3 / 4^{\prime \prime} \mathrm{ft} .{ }^{3}$ of rock is required per $\mathrm{ft} .{ }^{2}$ of collector area.

Collector Area $=$ $\mathrm{ft} .^{2}$

Volume $=\left(\overline{f t .} .^{3 / f t} .^{2}\right)($ ft. $\left.{ }^{3}\right)\left(100\right.$ lbs. $\left./ \mathrm{ft}^{3}\right)(1$ ton $/ 2,000$ lbs. $)=$ $\mathrm{ft}^{2}$ collector $)=. . .$. $\left.\mathrm{ft}^{3}\right) \div 27 \mathrm{ft}{ }^{3} / \mathrm{cu}$. yd: $=$

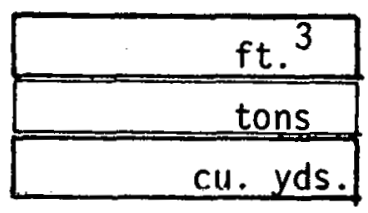

b. DIMENSIONS:

$\left.\mathrm{ft}^{3}\right) \div($ * ft. rock depth)

ft. 2 floor

Storage unit inside dimensions $=$

ft. long $x$

ft. wide

Minimum dimension of $3^{\prime}$ for length or width

c. ROCK SIZE: (see chart below)

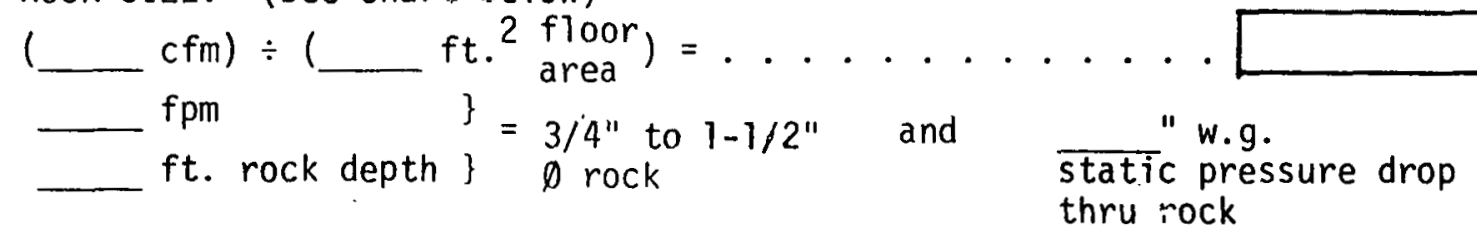

d. AIR INLET/OUTLET SIZES: Size duct connections at 800 to $1,000 \mathrm{fpm}$

Top:

Bottom: 8 "high $x$ "wide

(NOTE: Bottom upening must always be at least twice as wide as tonn npening to account for reslriction caused by bond beam block. Optional top opening as per pages 6 and 13.)

The following data should be used to determine the proper combinations of rock size and rock depth. Minimum allow. static pressure loss $0.12^{\prime \prime} \mathrm{w} . \mathrm{g}$.

\begin{tabular}{|c|c|c|c|c|}
\hline \multicolumn{5}{|c|}{ STATIC PRESSURE LOSS THRU PEBBLE BED STORAGE UNIT (INCHES W.G.) } \\
\hline $\begin{array}{r}\text { FACE VELO } \\
\text { ACROSS ROCK B }\end{array}$ & ITY & \multirow{2}{*}{$20 \mathrm{FPM}$} & \multirow{2}{*}{$25 \mathrm{FPM}$} & \multirow{2}{*}{$30 \mathrm{FPM}$} \\
\hline ROCK DEPTH-FEET & ROCK SIZE & & & \\
\hline $5^{\prime}$ & $\begin{array}{l}3 / 4^{\prime \prime} \text { to } \\
1-1 / 2^{\prime \prime}\end{array}$ & $0.12^{\prime \prime}$ & $0.22^{\prime \prime}$ & $0.31^{\prime \prime}$ \\
\hline $6^{\prime}$ & $\begin{array}{l}3 / 4^{\prime \prime} \text { to } \\
1-1 / 2^{\prime \prime}\end{array}$ & $0.14^{11}$ & $0.23^{\prime \prime}$ & $0.34^{\prime \prime}$ \\
\hline $7^{\prime}$ & $\begin{array}{l}3 / 4^{\prime \prime} \text { to } \\
1-1 / 2^{\prime \prime}\end{array}$ & $0.17^{\prime \prime}$ & $0.27^{\prime \prime}$ & $0.40^{\prime \prime}$ \\
\hline
\end{tabular}

* 5'0" minimum depth for commercial unit; 7'0" maximum rock depth.
(C) Copyright
May 1978
Solaron Corporation 


\section{HEAT STORAGE UNIT SIZING}

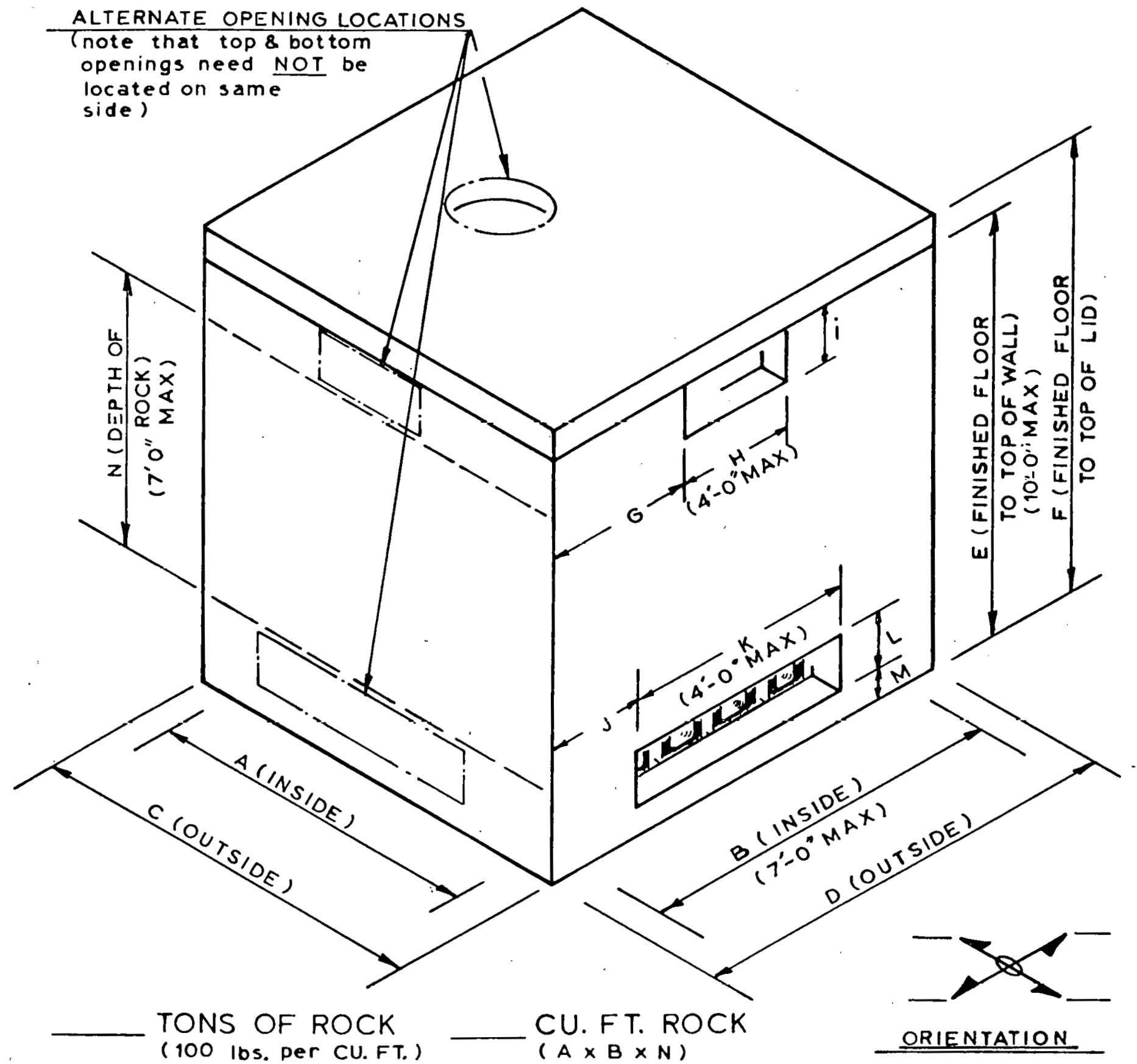

\begin{tabular}{|l|l|l|l|l|l|}
\hline \multicolumn{5}{|c|}{ DIMENSIONS } \\
\hline A & & F & & K & \\
\hline B & & G & & L & 8 $^{4}$ \\
\hline C & & H & & M & \\
\hline D & & I & & N & \\
\hline E & & J & & & \\
\hline
\end{tabular}

NOTE: $14 " \times 14 "$ high sidewall opening location can be used when air handler outlet is mounted directly to box.

(C) Copyright May 1978 Solaron Corporation 
COMMERCIAL HEAT STORAGE UNIT

CONCRETE CONSTRUCTION

1. WALL CONSTRUCTION TO BE 8" MINIMUM REINFORCED CONCRETE. VERTICAL AND HORIZONTAL RE-BAR:

A. 4 - \#5 RE-BAR CONTINUOUS 2 EACH FACE.

B. \#4 RE-BAR AT 8" 0.C. VERTICAL IN OUTSIDE FACE.

C. \#5 RE-BAR AT 8" O.C. HORIZONTALLY FOR 8" THICK WALLS.

D. DOWEL WALL TO FLOOR WITH ONE OF THE FOLLOWING:

1. \#4 RE-BAR "L" 1'-6" x 1'-6" AT 16" 0.C.

$O R$

2. $5 / 8 " \emptyset \times 8 "$ HEADED ANCHOR BOLT W/NUT AT $18 " 0 . \mathrm{C}$. $O R$

3. 5/8" $\emptyset$ EXPANSION ANCHOR W/5" BOLT AT $24 " 0 . C$.

CENTER ANY OF THE OPTIONS ON WALL.

2. FORM OUT FOR BOTTOM AND TOP OPENINGS AS REQUIRED FOR A GIVEN APPLICATION WITH $2 \times$ DIMENSION LUMBER WHICH SHOULD BE LEFT INTACT WHEN FORMS ARE REMOVED TO PROVIDE MOUNTING FRAME FOR DUCTWORK. PLACE TWO \#5 RE-BARS (1 ON EACH FACE) WITH 2:-0" PROJECTION AROUND ALL OPENINGS IN CONCRETE. PROTECT WOOD FRAAMING FROM AIRSTREAM WITH SHEET METAL COLLAR OR GYP BOARD. THE FINISHED FRAMED INSIDE DIMENSION SHOULD BE THE SAME SIZE AS THE DUCT. SEE EXAMPLE BELOW:

EXAMPLE: FOR AN 8" $\times 20 "$ DUCT, THE OPENING SHOULD BE

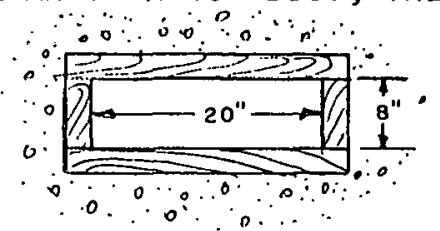

3. INSULATE INTERIOR SURFACE WITH 2" RIGID FIBERGLASS BOARD INSULATION ( 6 LB. DENSITY WITH R-8 MINIMUM), "CERTAIN-TEED \#IB600, 2" PLAIN. SECURE TO WALL. DO NOT USE STYROFOAM OR URETHANE INSULATION.

5. INSTALLATION SHALL COMPLY WITH ALL APPLICABLE NATIONAL AND LOCAL BUILDING CODES.
(C) Copyright
Ma.y 1978
Solaron Corporation 


\section{COMMERCIAL \\ HEAT STORAGE UNIT \\ CONCRETE}

NOTE :

IF AIR HANDLER LOCATION OPTION NO.I IS USED A 14" $\times 14$ "OR 18 " $\times 18$ " OPENING WITH ROCKS SCOOPED AWAY SHALL BE NEEDED SEE pg. 12

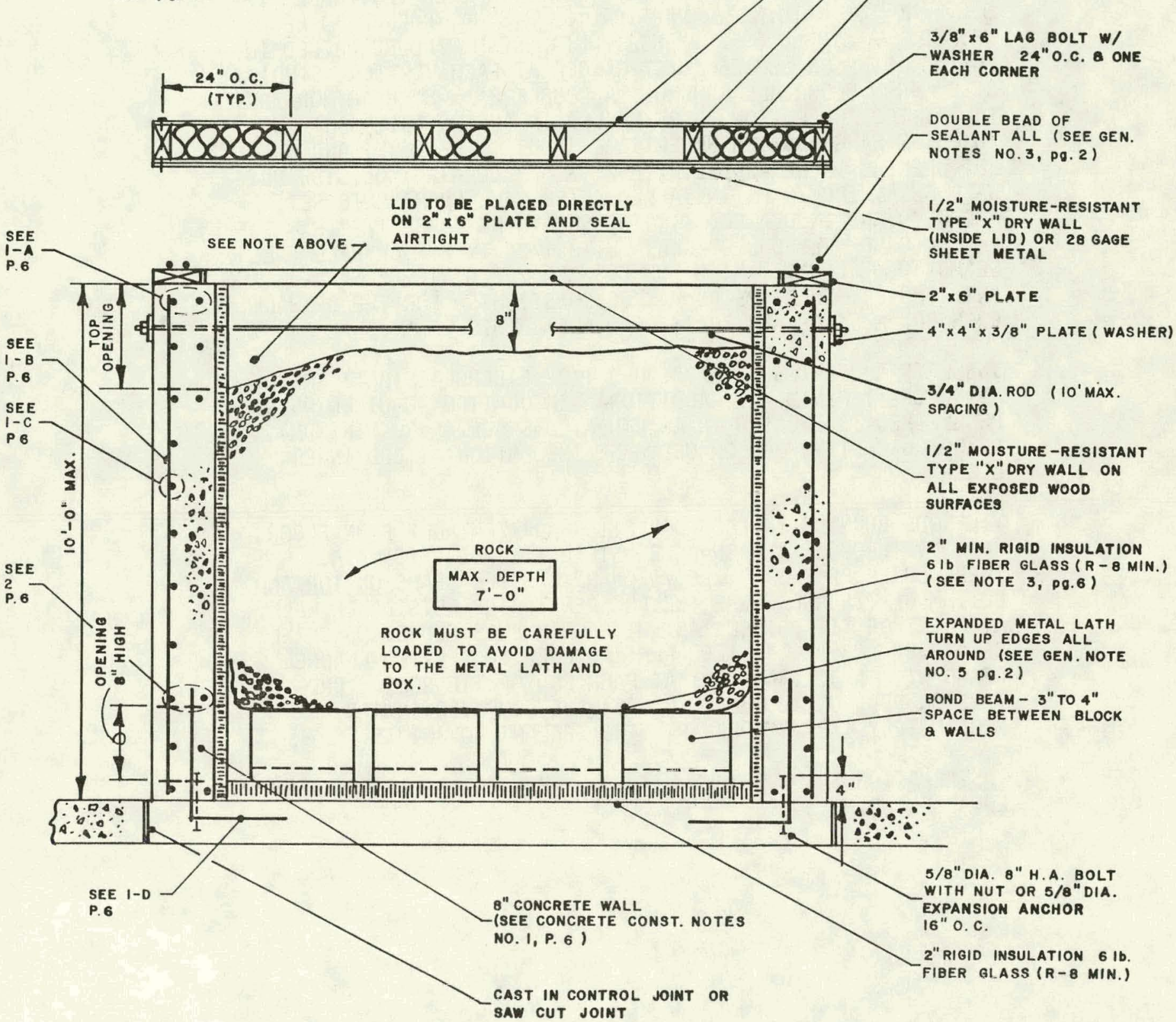

NOTE: INSULATION R-II MIN. (R-3O IN UHEATED AREA)

(C) Copyright May 1978 Solaron Corporation 
COMMERCIAL HEAT STORAGE UNIT

WOOD CONSTRUCTION

1. WALL CONSTRUCTION TO BE SINGLE $2 " \times 8$ " NAILED VERTICALLY 16 " O.C. (NO TOE NAILING). VERTICAL $2^{\prime \prime} \times 8^{\prime \prime}$ AT CORNER TO BE NAILED. A SINGLE 2" $\times 8^{\prime \prime}$ HORIZONTAL BEAM WILL BE NAILED IN (USING 'SIMPSON' LU 26 JOIST HANGER AT EACH VERTICAL STUD) 6'-0" FROM FLOOR ALL AROUND. A DOUBLE 2" $\times$ 8" BEAM HORIZONTAL AT TOP AND BOTTOM TO BE NAILED IN (USING 'SIMPSON' LU 26 JOIST HANGER AT EACH VERTICAL STUD). THE INLET AND OUTLET OPENING TO BE FRAMED WITH 2" $\times$ 8" BLOCKING; OUTSIDE DRYWALL SHEATHING TO BE INSTALLED AFTER WALL FRAMING IS SET, ANCHORED AND INSULATED. INSIDE SHEATHING TO BE $1 / 2^{\prime \prime}$ EXTERIOR GRADE PLYWOOD OVERLAID WITH 1/2" TYPE X DRYWALL (ALL SEAMS TO BE CAULKED WITH DOW CORNING 732 SILICONE SEALANT. 28-GA. SHEET METAL MAY BE SUBSTITUTED FOR THE DRYWALL. ROCK BOX MUST BE AIRTIGHT; SEAL ALL JOINTS.

2. INSULATE ALL VOIDS WITH $3^{\prime \prime}$ TO 3-1/2" FIBERGLASS BATT INSULATING (R-11 MINIMUM). ADDITIONAL INSULATION REQUIRED WHEN PEBBLE BED IS LOCATED IN AN UNHEATED SPACE (R-30 MINIMUM). DO NOT USE STYROFOAM OR URETHANE INSULATION AS BED INNER LINER.

3. TIE RODS RUNNING IN EACH DIRECTION HORIZONTALLY FROM FLOOR $\left(6^{\prime}-0^{\prime \prime}\right)$ THROUGH WALL SHALL BE STEEL TIE RODS $7 / 8^{\prime \prime}$ DIA. THERE SHALL BE TWO $5^{\prime \prime} \times 6.7$ \# CHANNEL STEEL BEAMS ON TOP AND BOTTOM OF TIE ROD WHERE THE ROD PENETRATES OUTSIDE OF WALL. AI PUINI UF IIE RUU CUNIACI WIIH CHANNEL STEEL BEAMS SHALL BE A $3 / 8^{\prime \prime} \times 3^{\prime \prime} \times 3^{\prime \prime}$ STEEL PLATE WELDED TO THE TWO CHANNEL BEAMS WITH A BOLT AND NUT AT EACH END OF TIE RODS. PRETENSION RODS UNTIL WALL CENTERS HAVE CONCAVED INWARD APPROXIMATELY 1/8" BEFORE APPLYING SEALANT TO JOINTS.

4. INSTA.LLATION SHALL COMPLY WITH ALL APPLICABLE NATIONAL AND LOCAL BUILDING CODES.

(C) Copyright May 1978 Solaron Corporation 


\section{COMMERCIAL \\ HEAT STORAGE UNIT \\ WOOD}

wOTE:

IF AIR MAMDLER LOCATION OPTION MO.I IS USED A $14^{\prime \prime} \times 14^{\prime \prime}$ OR $18^{\prime} \times 10^{\prime}$ OPENIN WITH ROCKS SCOOPED AWAY SHALL BE MEEDED

SEE 12

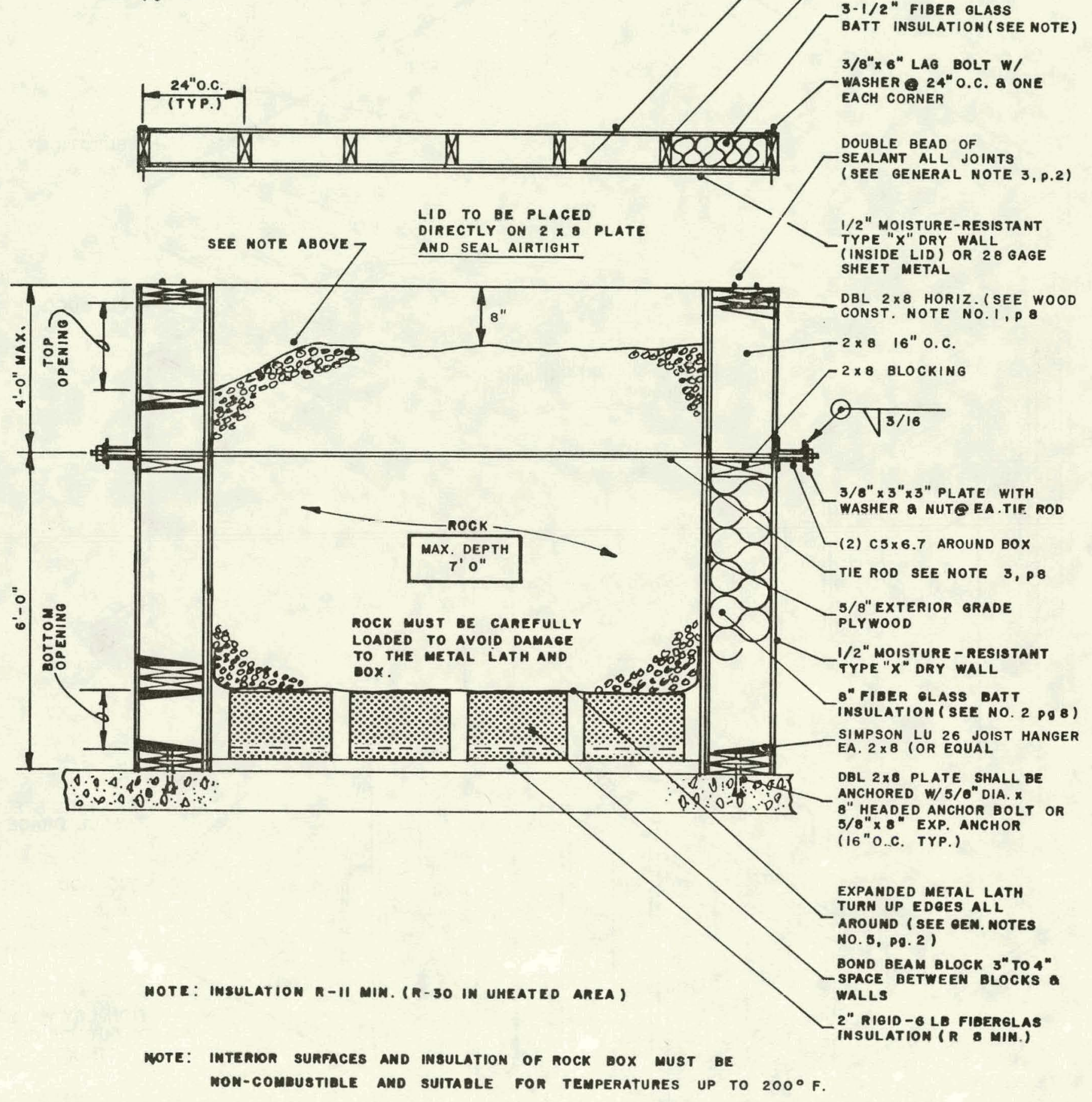

(C) Copyright May 1978 Solaron Corporation 


\section{COMMERCIAL \\ HEAT STORAGE UNIT \\ WOOD}

NOTE:

ALL SURFACES IN CONTACT

WITH AIR STREAM MUST BE

COVERED WITH NON - COMBUSTIBLE

MATERIAL (STEET METAL OR

GYP. BOARD )

PENING

DRY WALL OR
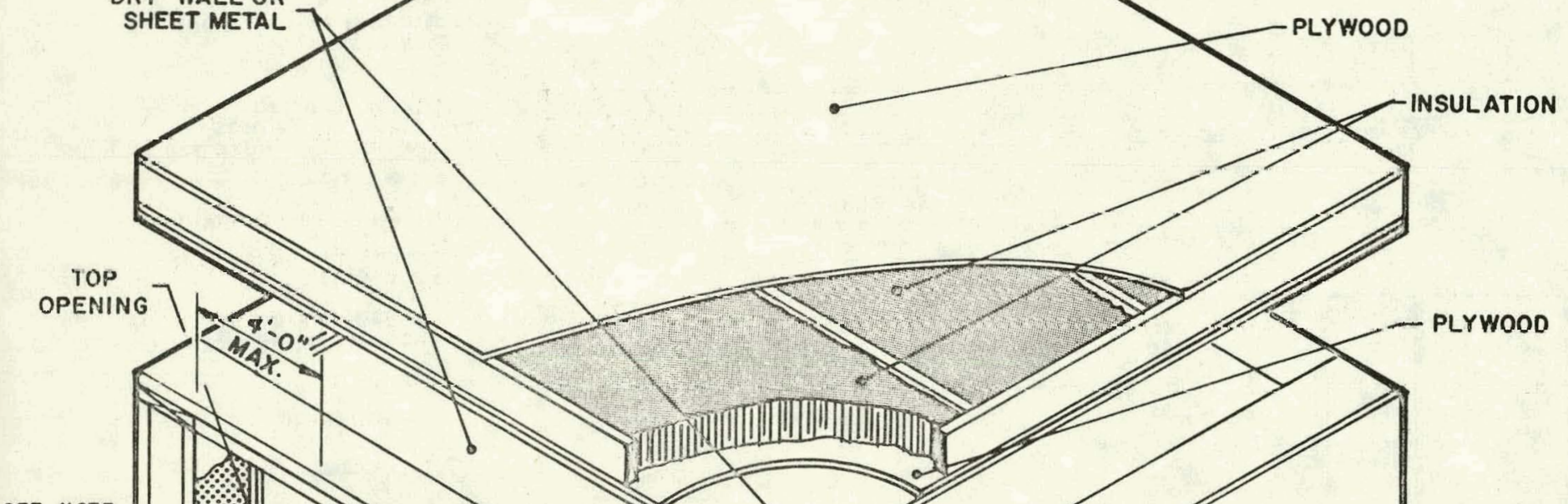

SEE NOTE

BOND BEAM

BLOCK

SEE NOTE BELOW

SEE MOTE ADOVE

NOTE:

BOND BEAM BLOCK MUST BE PERPENDICULAR TO WALL CONTAINING DOTTOM OPENINE
(C) Copyright
May 1978
Solaron Corporation 


\section{COMMERCIAL HEAT STORAGE UNIT ATTACHMENT DETAILS}

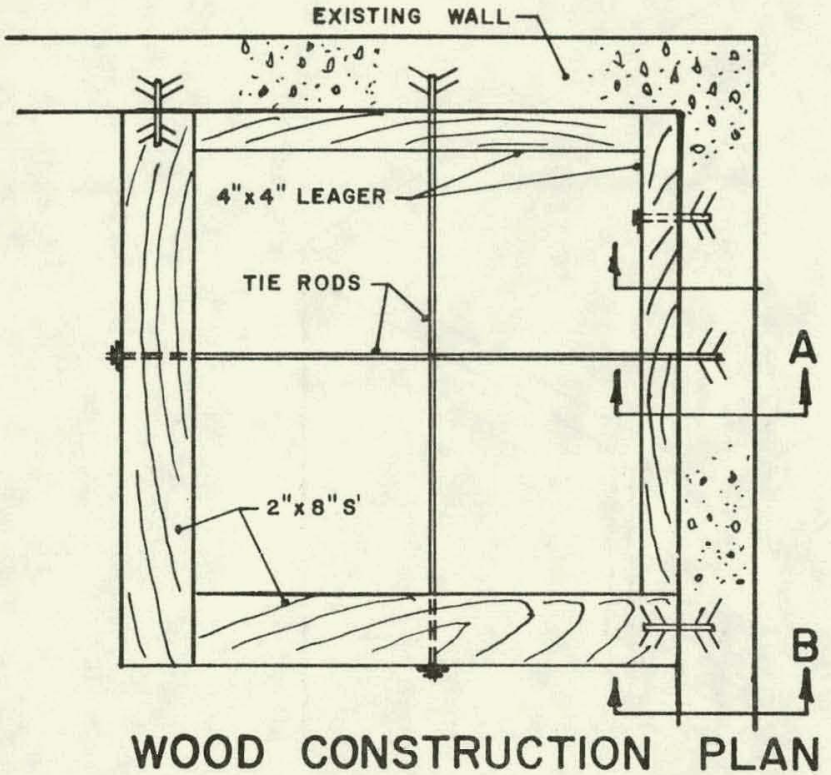

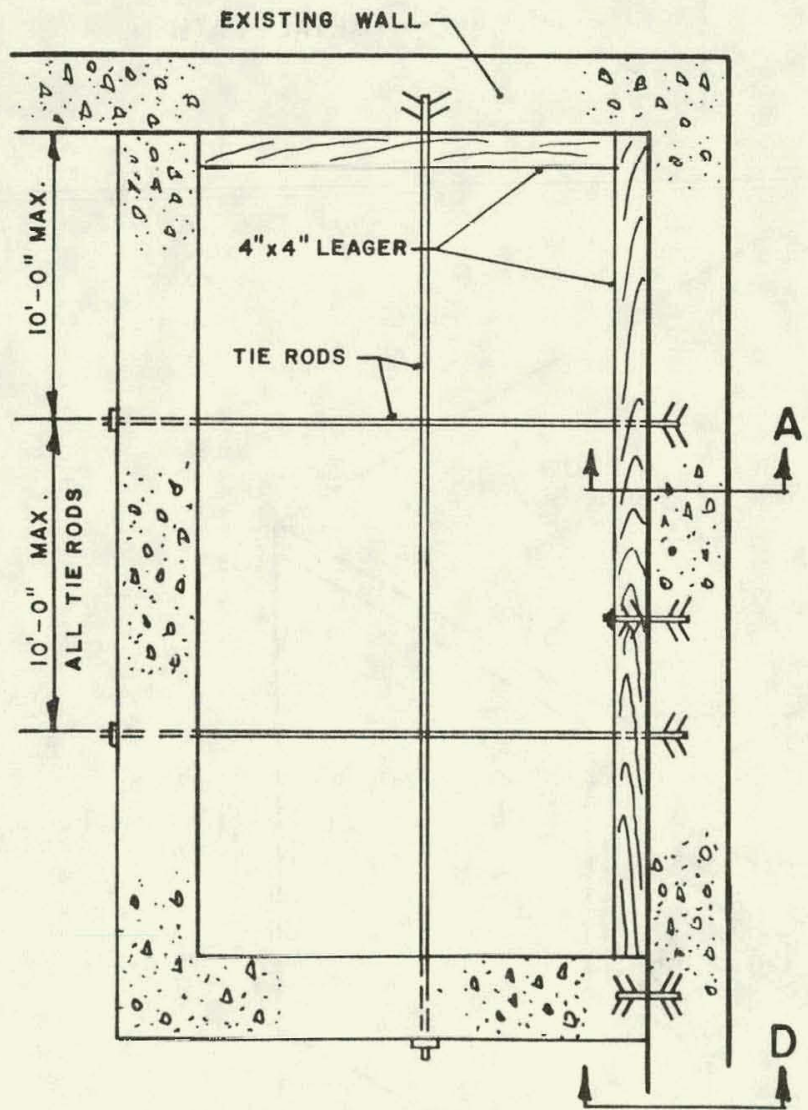

CONCRETE CONSTRUCTION PLAN

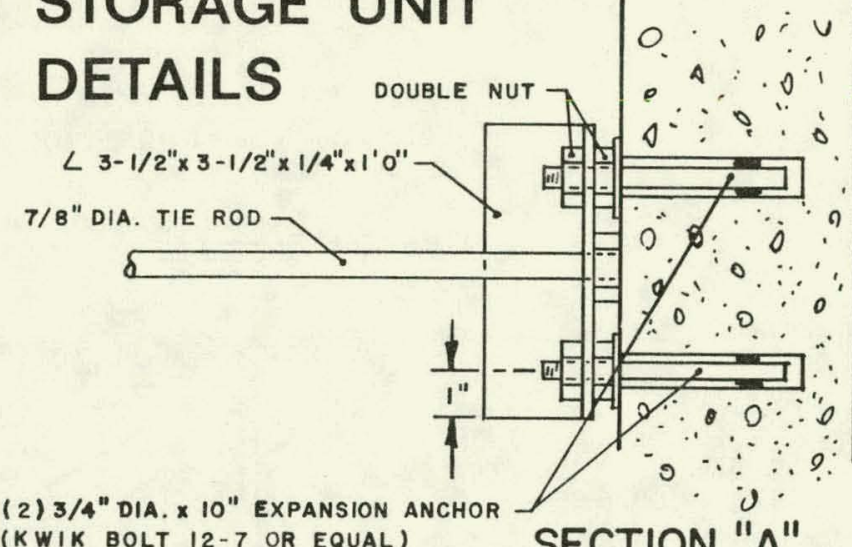

(KWIK BOLT I2-7 OR EQUAL) SECTION "A"
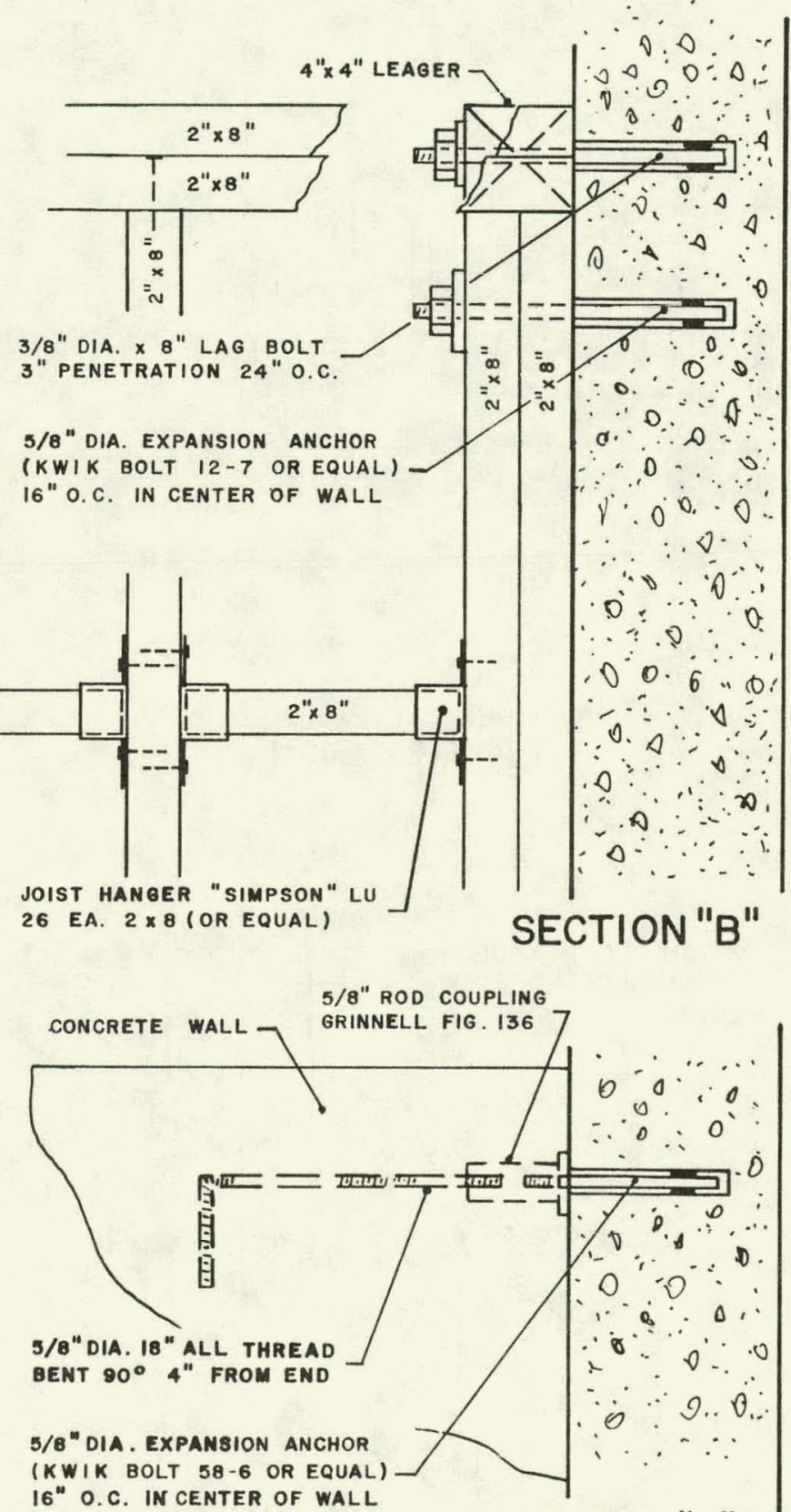

SECTION "D"

(C) Copyright May 1978 Solaron Corporation 


\section{OPTIONAL AIR HANDLER \& DUCT LOCATIONS}
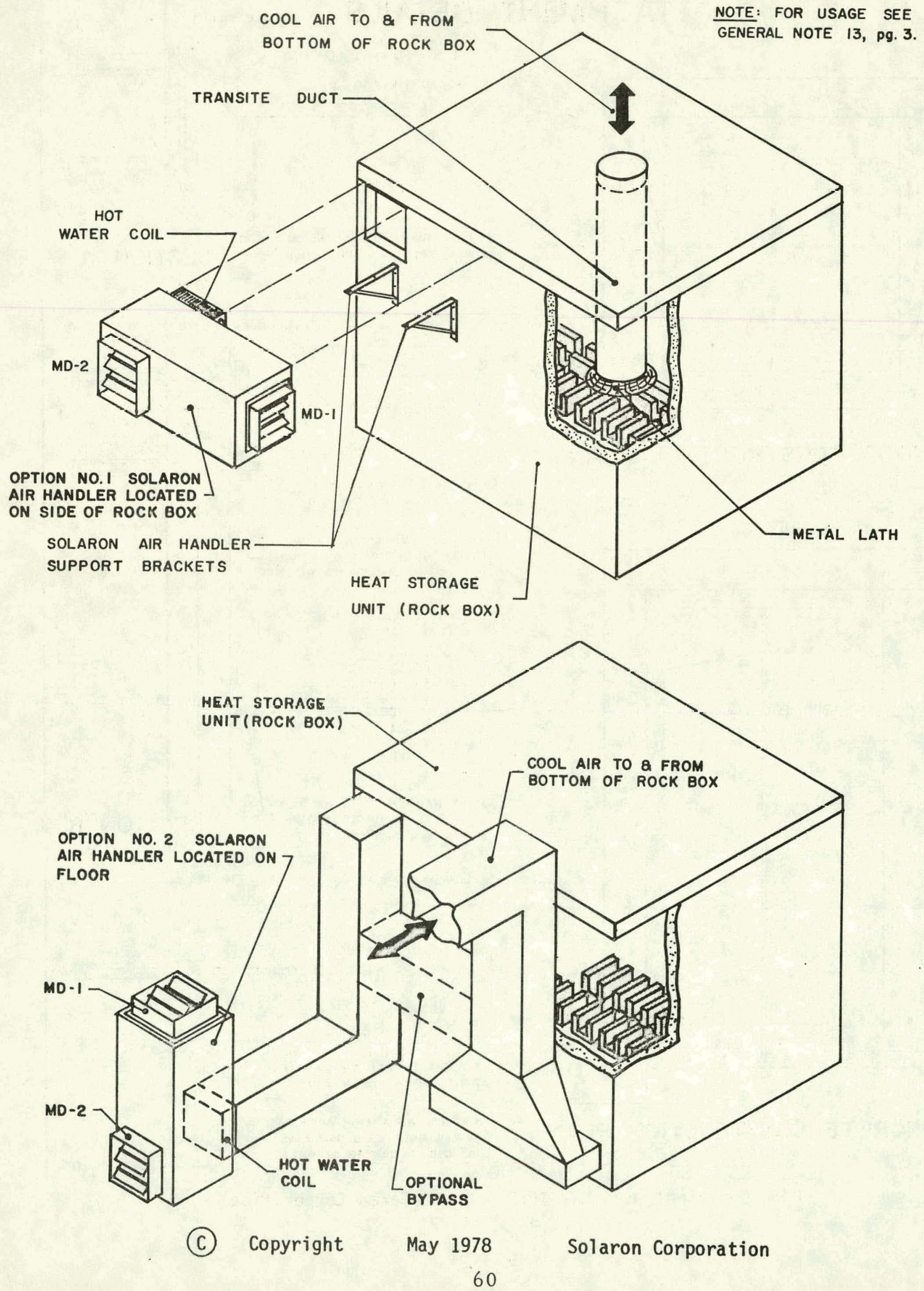


\section{METAL LATH SAMPLE}

(MUST BE GALVANIZED)

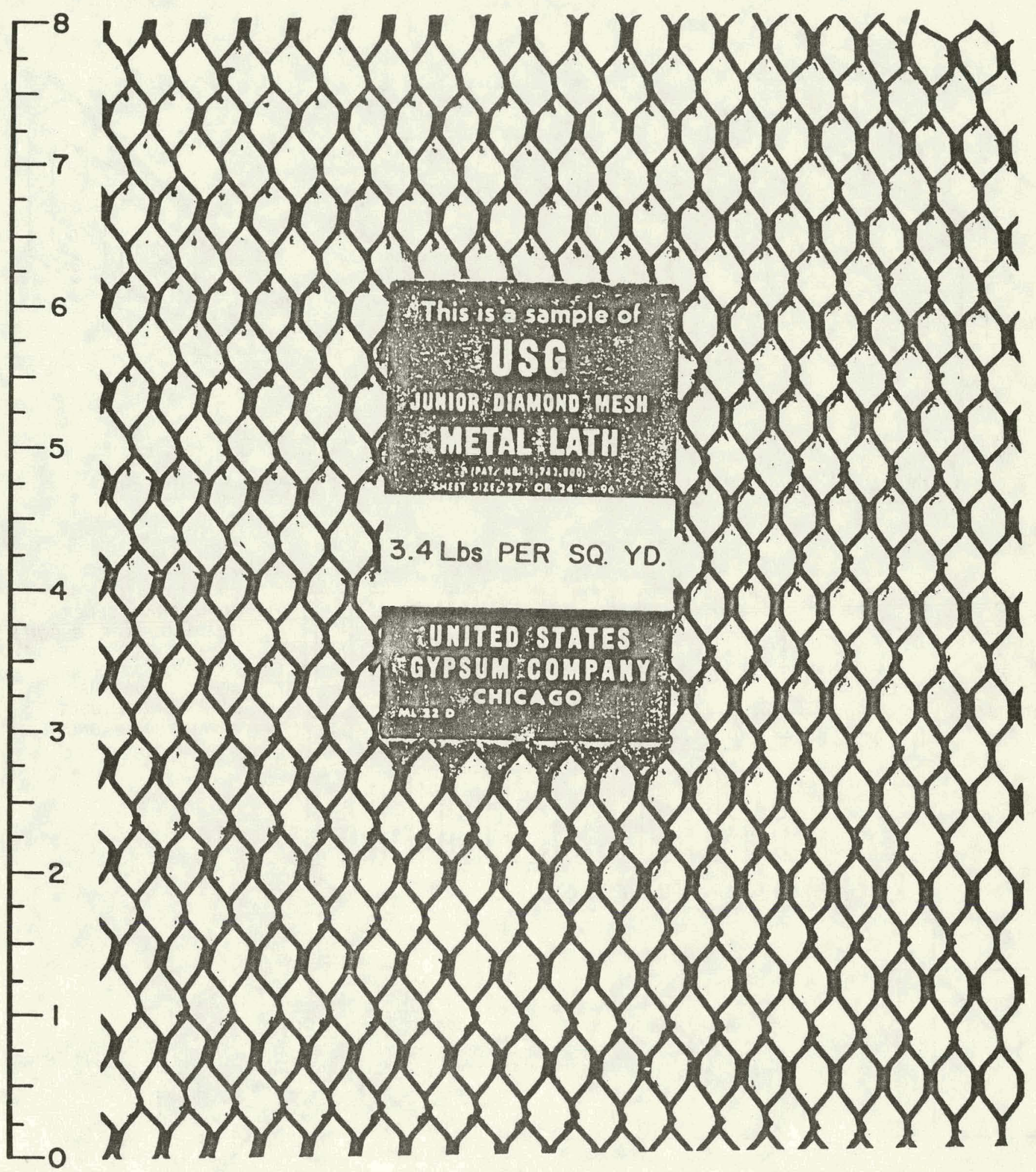

(C) Copyright May 1978

Solaron Corporation 


\section{BOND BEAM BLOCK \& TRANSITE DUCT}
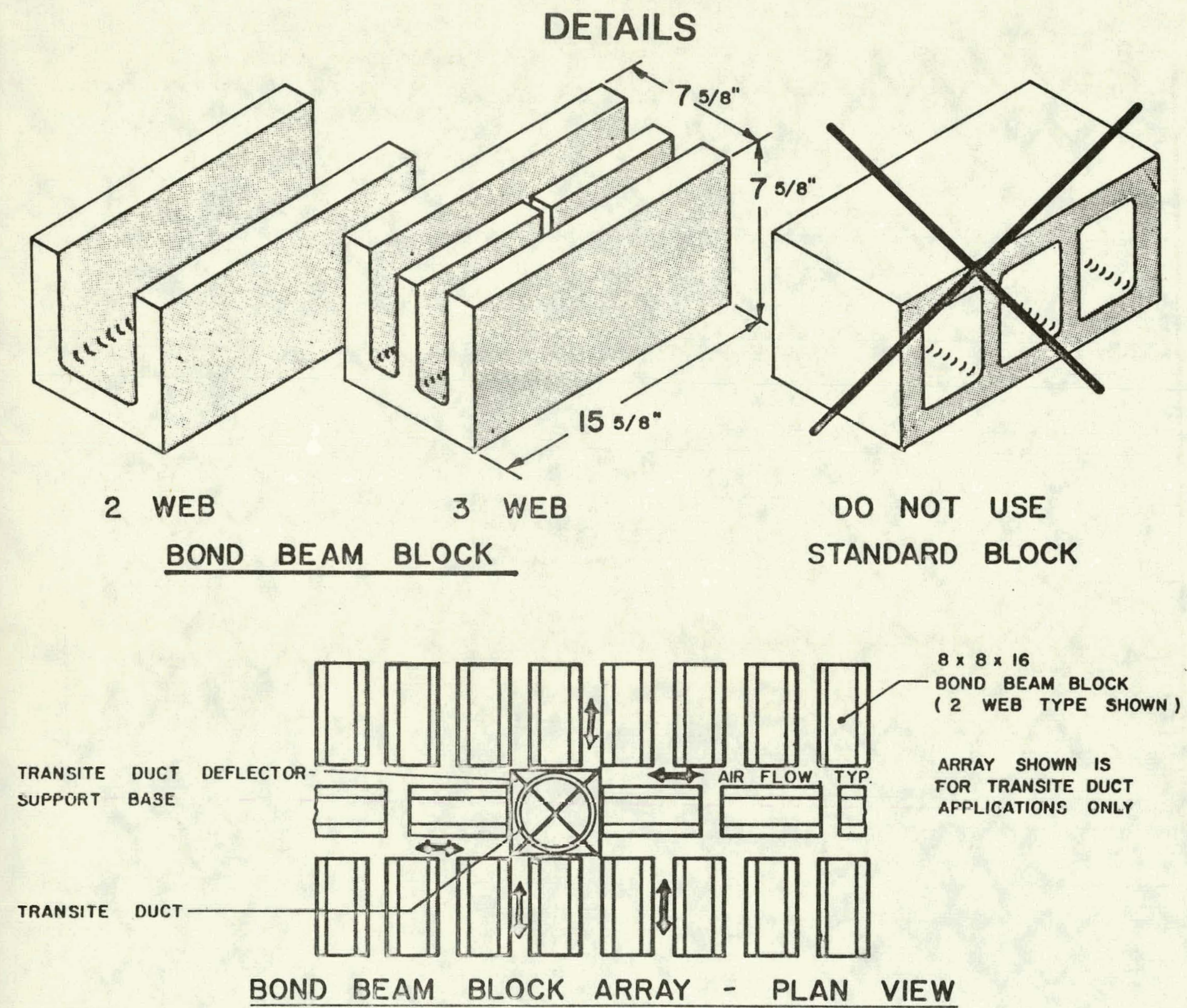

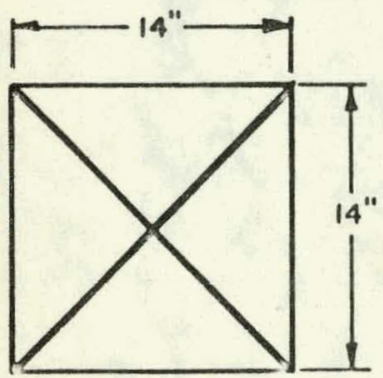

TOP

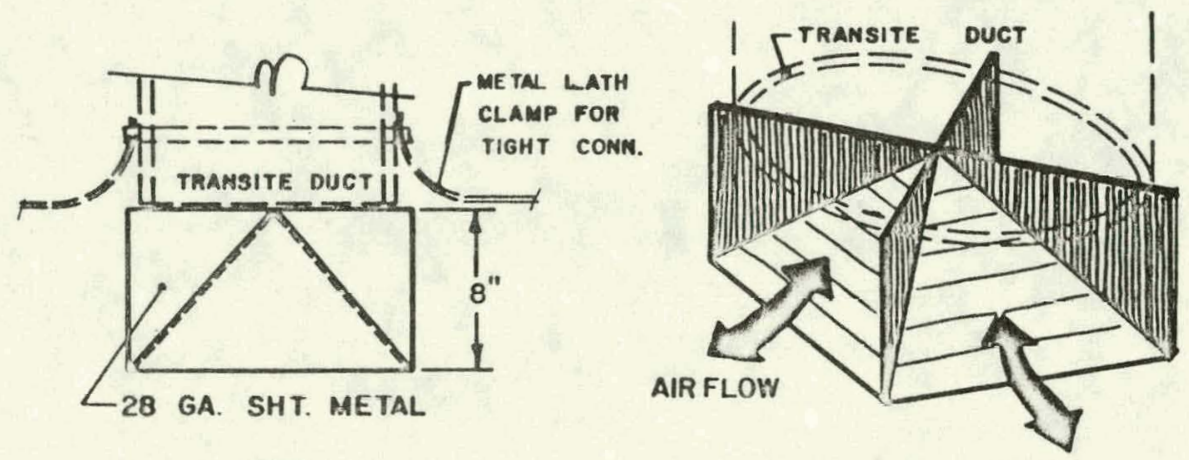

ISOMETRIC

TRANSITE DUCT DEFLECTOR-SUPPORT BASE

(C) Copyright May 1978 Solaron Corporation 


\section{ROCK \& SIZING METHOD}

ANY ROCK USED IN THE HEAT STORAGE UNIT MUST BE CLEAN AND CONTAIN LESS THAN 5\% FINES. ROUND RIVER BED ROCK OF A GRANITE TYPE IS PREFERRED. HOWEVER, FRACTURED HARD ROCK MAY BE USED.

WASH ALL ROCK BEFORE IT IS INSTALLED IN THE HEAT STORAGE UNIT. WASHING MAY TAKE PLACE AT THE QUARRY OR AT THE JOB SITE. ROCK MAY BE POURED INTO PLACE WHILE IT IS DAMP BUT SHOULD NOT BE DRIPPING WATER. UNDER NO CIRCUMSTANCES SHOULD ROCK BE WASHED AFTER IT IS IN PLACE.

\section{ROCK SIZING METHOD}

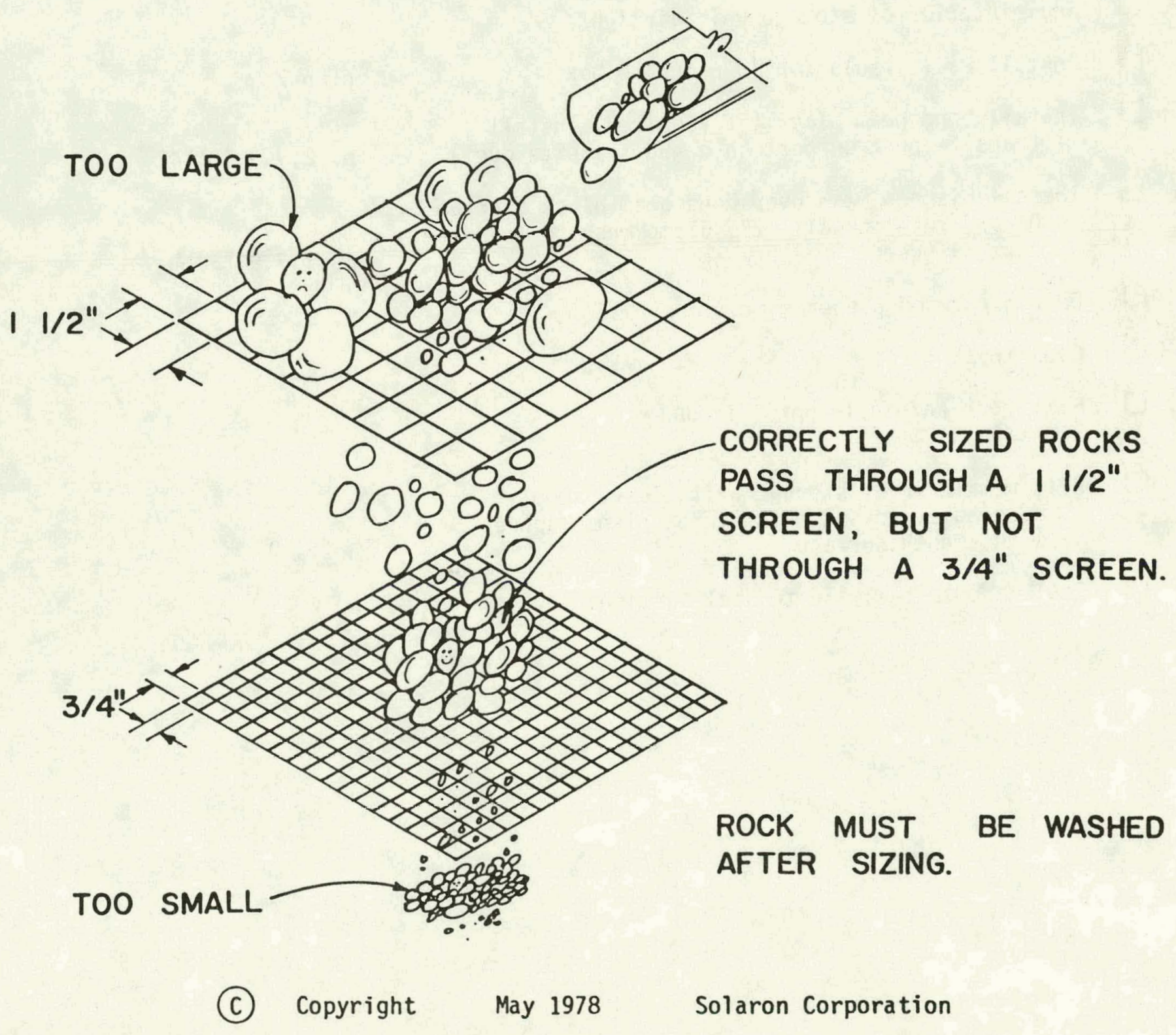


HEAT STORAGE UNIT

CONSTRUCTION CHECK LIST

Refer to

p. 4

p. I

Determine location of storage unit

p. 1

Excavate (if required)

p. 2

Prepare and install footings

p. $(j-j 2$

Construct walls of storage unit

p. $7-12$

Install tie rod thru walls of storage unit

p. ?

Seal interior of storage unit airtight

p. 6-7

Install wall insulation in concrete box

p. $2,7,9,10,14$

Install bond beam block (if required, install transite duct support base and transite duct)

Install diamond mesh over bond beam block overlap $6^{\prime \prime}$ and turn up wall 12". Clamp mesh to transite duct, if used

p. $2,7,9,13,14$

Obtain rock of proper size

p. 2,15

clean ruck

p. 2,15

Fill rock carefully onto diamond mesh

p. 6,8

Fill remainder of storage unit, leave supply opening clear and maintain 8" plenum space with smooth surface

p. 6,8

$\square \quad$ Caulk and install lid to seal airtight

p. 2 
OWNER'S MANUAL 


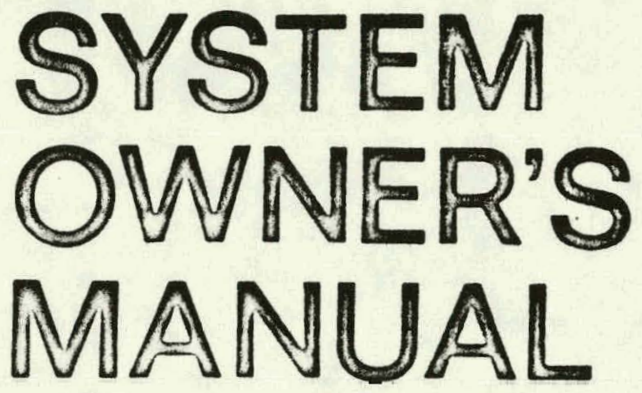

SPACE HEATING

SPACE HEATING

DOMESTIC WATER PREHEAT

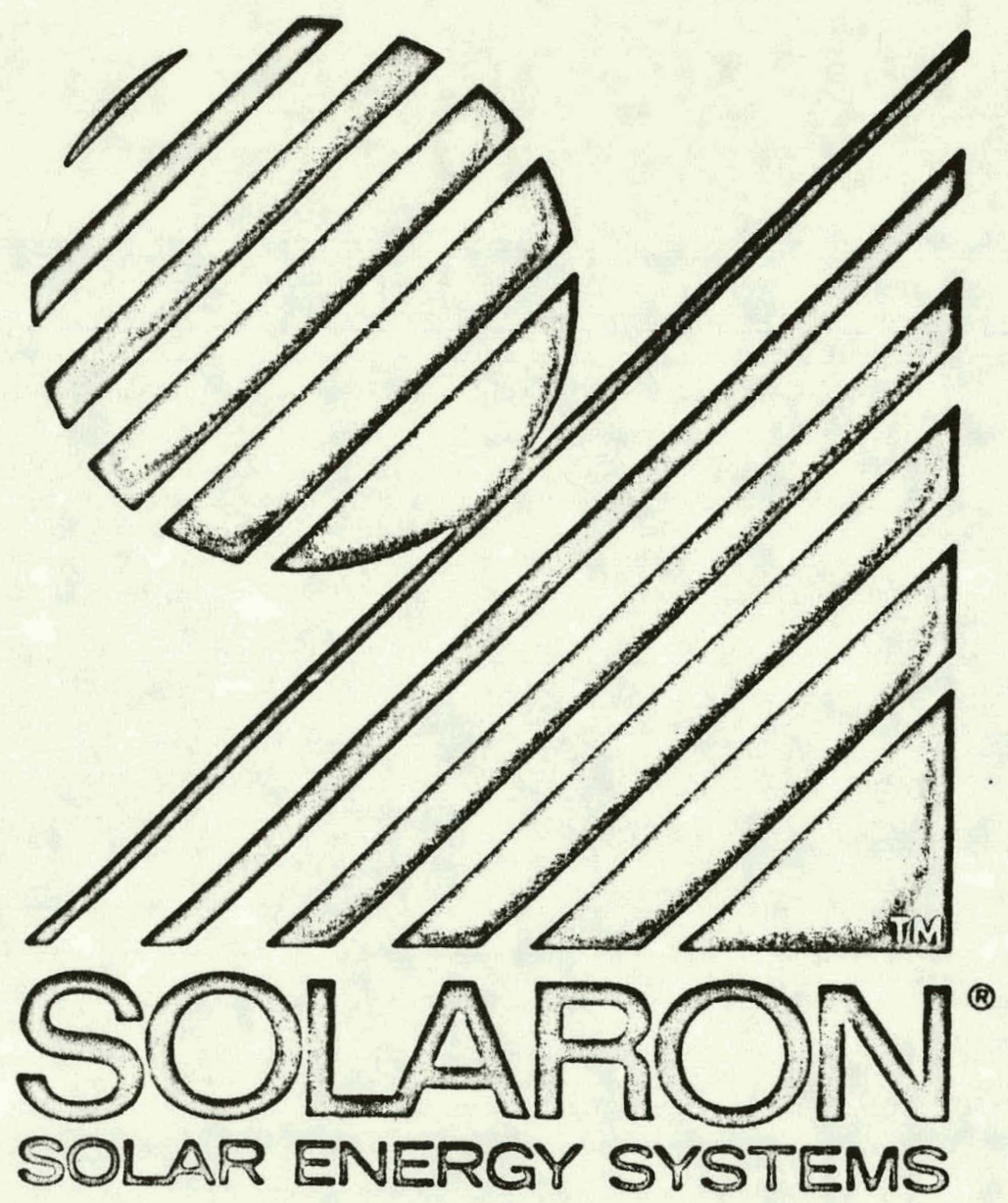




\section{SOLARON ${ }^{\oplus}$ CORPORATION SYSTEM OWNER'S MANUAL}

You are to be congratulated on what could well be the most gratifying purchase you will ever make in your life. By reading the material contained within this manual you will be able to better understand and appreciate not only your investment, but also your personal contribution to help in easing the Nation's energy crisis.

\section{CONTENTS}

PAGE NO.

- A Description of your SOLARON"System . . . . . . . 68

- Overview of System . . . . . . . . . . . 68

- General System Description. . . . . . . . . . . . 69

- Collectors ......................... 73

- Heat Storage. . . . . . . . . . . . . . . . 74

- Solaron Air Handling Unit . . . . . . . . . . . . 76

- Gravity-Operated Dampers . . . . . . . . . . . . . 76

- Domestic Water Preheater . . . . . . . . . . . . . . 76

- System Controls ...................... 77

- Auxiliary Heating System . . . . . . . . . . . . 77

- How to Operate your SOLARON ${ }^{\star}$ System .......... 81

- Routine Maintenance . . . . . . . . . . . . . . . . 83

- Steps to Follow to Obtain Maximum Performance from your SOLARON"System. .............. 84

- If your SOLARON"System Does Not Work ........ 86

System Installed By:

System Supplied By:

Solaron is a registered trade name of the Solaron Corporation.

Copyright 1978 Solaron Corporation, 720 So. Colorado BIvd., Denver, Colorado 80222. 


\section{A DESCRIPTION OF YOUR SOLARON ${ }^{\star}$ SYSTEM}

\section{Overview of System}

Space heating with solar energy has been the subject of research and development in the United States since 1938 when MIT built its first solar heated house. In 1943. Dr. G.O.G. Löf built and installed a successful snlar air heating system in his home in Boulder, Colorado; a prototype system, also using circulating air, has worked continuously in his Denver home since 1957 with no major problems and minor maintenance cost.

Thus, the technology of space heating by a solar energy air system has been well developed for a number of years and could have been applied to large scale use if it was economical. However, low fossil fucl and electrical energy costs discouraged the use of relatively expensive solar heating systems until the 1973 oil and energy shortages. When fuel and electricity prices began a rapid upward spiral, solar heating became economically competitive in many parts of the world.

In early 1974, Dr. Löf and several associates organized Solaron Corporation to design, manufacture, and market solar heating systems for residential, commercial, and industrial buildings. The company's technical staff designed a solar air heating production model, based on Dr. Löf's knowledge and the accumulated years of practical experience with the 1957 prototype system in the Lïf residence. Since 1974, Solaron has furnished solar heating systems for a large number of residences and commercia! buildings throughout the U.S.A. and overseas.

The Solaron Corporation solar heating system is effective in residential, commerical and industrial buildings. Air is the circulating heat transfer medium. The patented flat plate collector array consists of a combination of factory preassembled panels which can be mounted directly on a south facing roof of proper tilt, with proper supports on a flat roof or in another suitable location near the space to be heated. A factory preassembled air handling unit containing automatically actuated dampers, an optional domestic water preheater and a temperature control panel completes the Solaron package. A full-size, auxiliary conventional heating system and the installation labor are provided by others. 


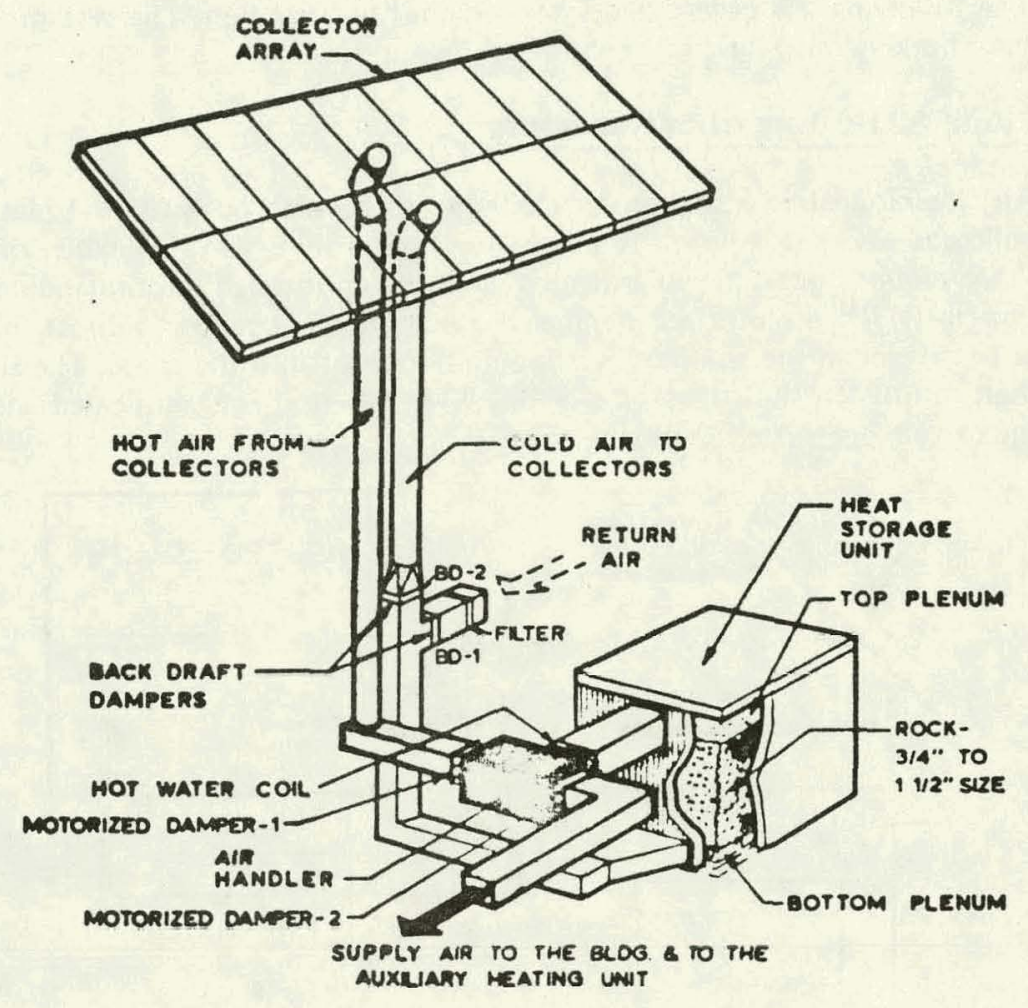

GENERAL SYSTEM DESCRIPTION

This drawing is intended to show a typical installation and relationship of the collectors, air handler, heat storage unit, motorired dampers, backdraft dampers and domestic water coil. The dampers used in solar AIR systems are very important to the successful operation of the system. Therefore, Solaron provides special dampers with airtight seals which are designed for long life and trouble-free service. The purpose or function of each damper is described below:

- MD-1: Motorized damper. Closes to prevent cold air from falling from the collector and leaking into the system in the "Heating from Storage Mode"

- MD-2: Motorized damper. Closes in the "Storing Heat Mode" to direct air to the heat storage unit.

- BD-1: Backdraft damper. Closes in the "Storing Heat Mode" to prevent reverse flow down the return air duct.

- BD-2: Backdraft damper. Closes in the "Heating from Storage Mode" to prevent the possibility of cold air from being drawn down from the collector and leaking into the system. 
The following are generalized system modes of operation. The system in your building may have different design features.

\section{Mode A. Heating from Collectors}

Air, the circulating heat transfer medium, is drawn through the flat plate collector where it is normally heated to about $120^{\circ} \mathrm{F}-150^{\circ} \mathrm{F}$. When the space requires heat, the solar heated air is drawn through the air handling unit in which a motorized damper is automatically opened to direct the hot air through the auxiliary heating unit and out into the space. The air then returns to the collector at about $70{ }^{\circ} \mathrm{F}$ where it is again heated and the cycle repeats itsclf.

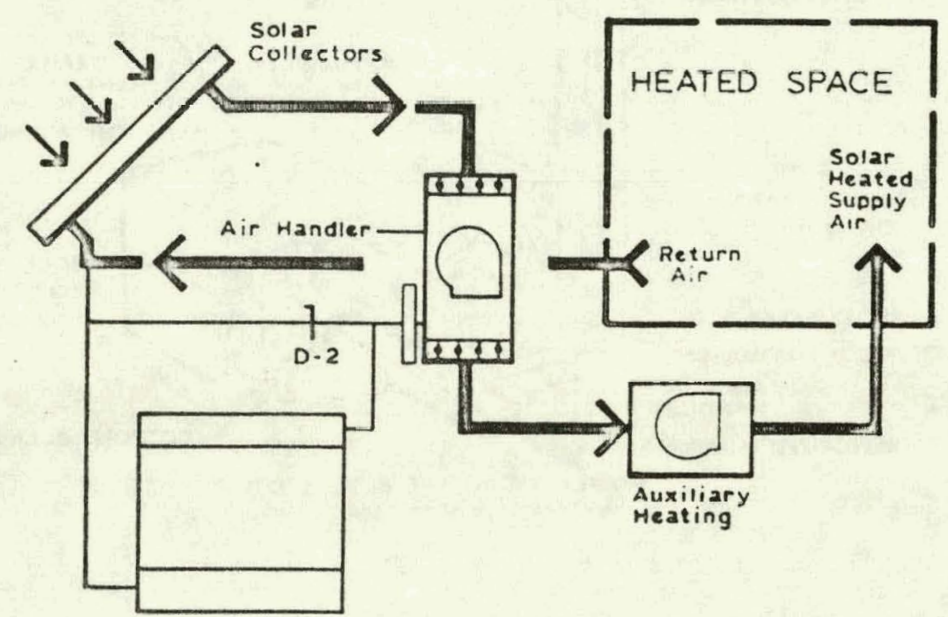

\section{Mode B. Storing lleat}

When the space temperature is satisfied, the automatic control system diverts the solar heated air into the heat storage unit where the heat is absorbed by the pebble bed. Relatively cool air from the bottom of the heat storage unit (i.e., normally at $70^{\circ} \mathrm{F}$ ) returns to the collector where it is heated.

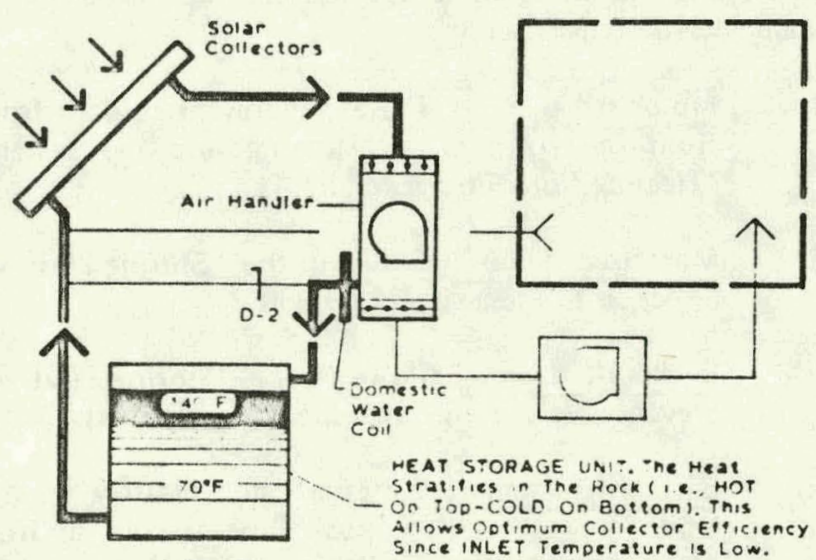




\section{Mode C. Heating from Storage}

At night or on cloudy days when solar energy is unavailable and when heat is needed in the space, the automatic control system directs the building return air into the bottom of the heat storage unit, up through the pebbles where the air is heated, through a portion of the air handling unit and into the space via the auxiliary heating unit fan. When the solar heated air does not maintain the space thermostat setting, the automatic control turns on the auxiliary heater to add the required heat.

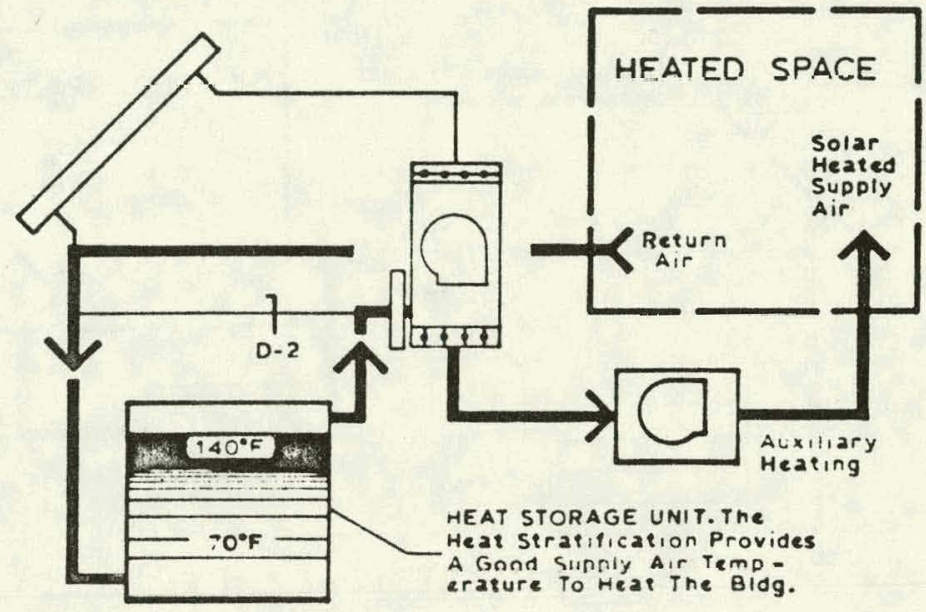

\section{Mode D. Summer Water Heating}

In the summer, when space heating is not required, air is drawn through the collector where it is heated and then across the water heat exchanger coil. The solar heated air transfers its heat to the water which is being circulated through the coil and the cooled air is then return back to the collector inlet.

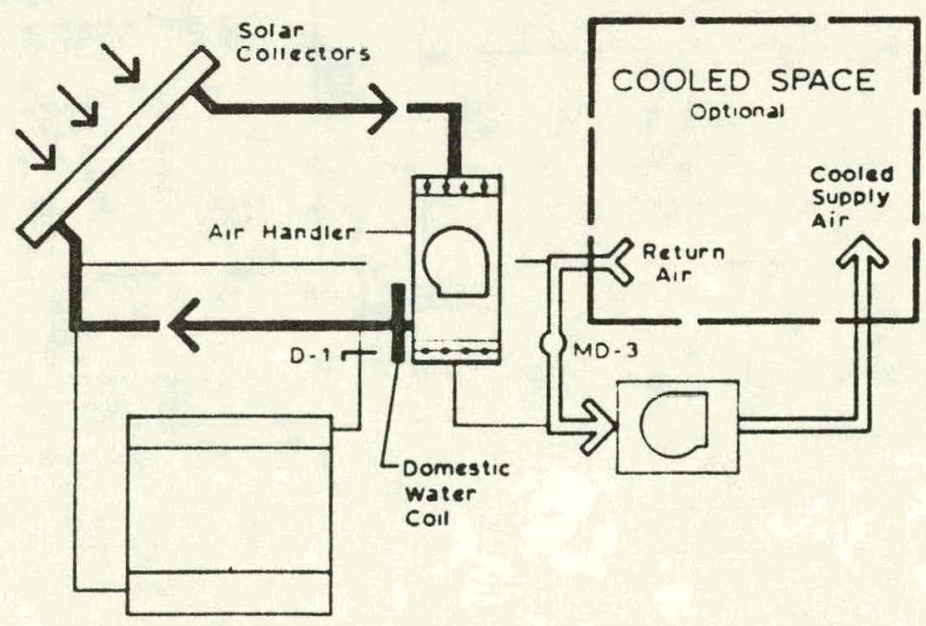




\section{Mode E. Heat Pump Systems - Second Stage Heating (solar energy available)}

Heat pump systems should not operate in their heating mode when the return air temperature is high (above $75^{\circ} \mathrm{F}$ ). Therefore, on a call for second stage heating with heat pumps, the solar system is bypassed. All the return air goes through the MD-3 bypass damper to the indoor heat pump unit. Note the solar energy is not wasted since it will go into storage and be used later when there is a call for first stage heating.

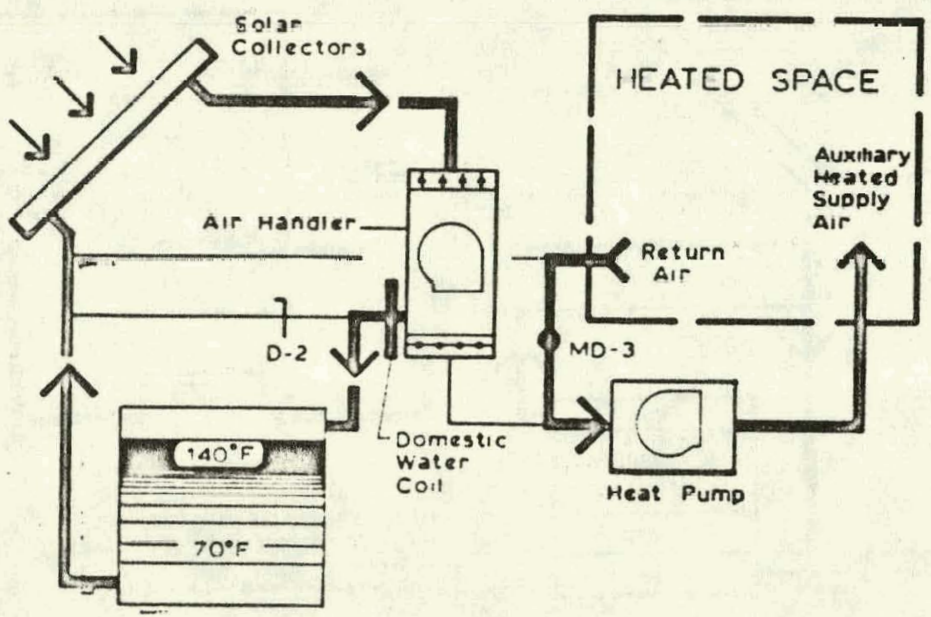

Mode F. Heat Pump Systems - Second Stage Heating (no solar)

This is the same as Mode E except the solar air handling unit is not storing heat. All the return air goes through MD-3. As soon as there is a call for first siage hrating the system will heat from storage and the system operates as in Mode C.

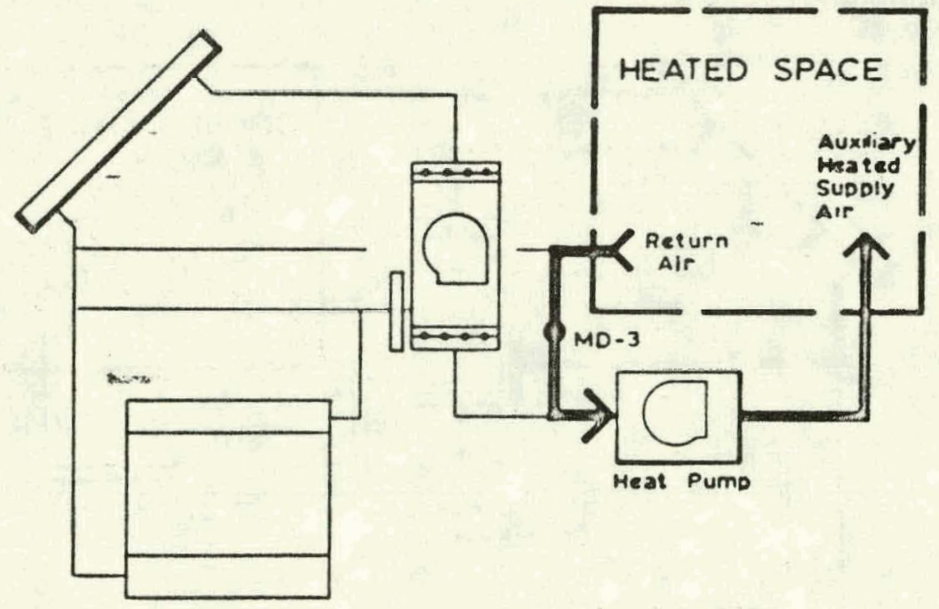




\section{Collectors}

The Solaron air heating collector has a flat absorber and heat exchanger plate, is internally manifolded and insulated, is constructed of steel and is covered by special high transmittance glazing. The solar radiation is absorbed and converted to useful heat energy with air as the transfer medium. The collector is subjected to its most severe thermal conditions of up to $400^{\circ} \mathrm{F}$ when it is in direct sunlight and the system is not operating because there is no heating requirement. The collector performance is optimal if it is oriented due South and tilted at an angle of latitude plus 5 to 15 degrees for space heating and latitude minus 5 degrees for domestic hot water heating and many process heat applications. A variance of 60 degrees from due South, as an example, will generally require an additional 20 percent collector area and a 5 degree variation in tilt from optimum will require approximately 3 percent additional collector area.

The air flow in the Solaron collector passes beneath the absorber in a duct that is formed by the absorber and a second metal sheet. The absorber, therefore, is insulated by a dead air space between it and the glazing. This design makes for a more efficient collector in most applications and protects the absorber surface from dust or other airborne contamination.

The collector utilizes a patented air manifold system to minimize field installation labor and assure uniform high performance. The manifold system replaces most of the ductwork normally used to interconnect other types of air heating collectors.

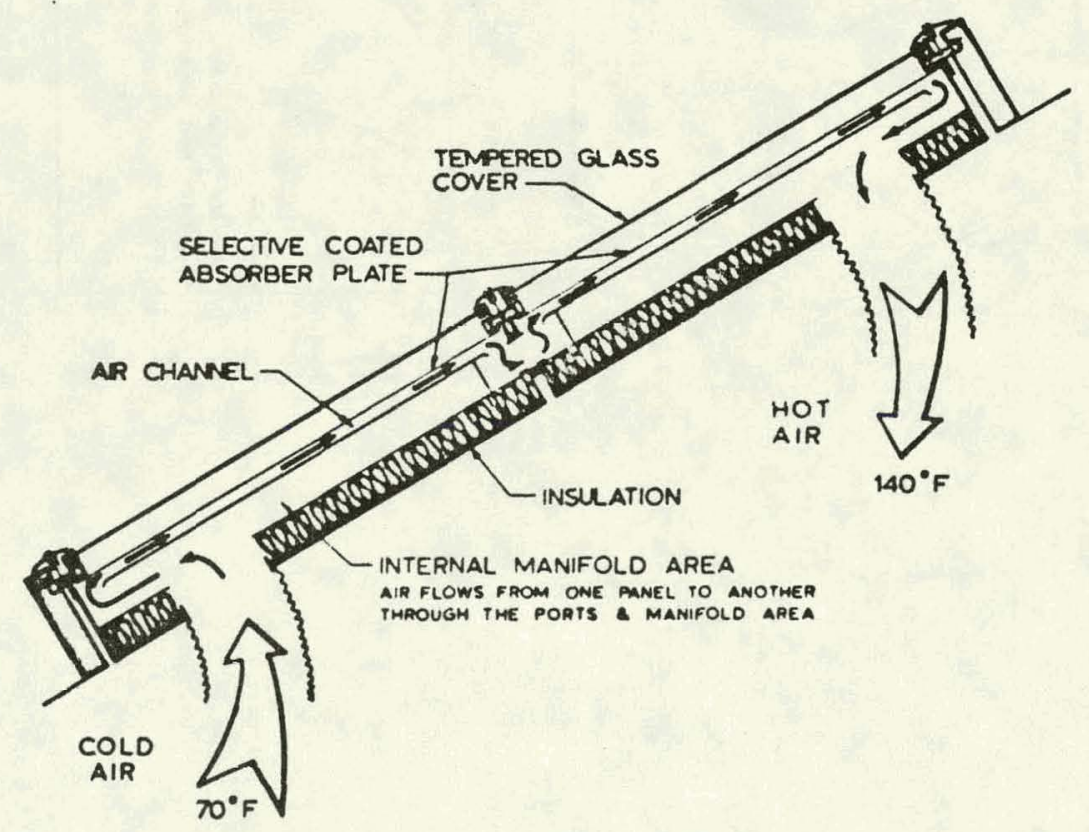




\section{Heat Storage}

The use of pebbles in the heat storage unit is particularly effective with an air circulating solar heating system. The pebble bed maintains a steep temperature stratification (i.e., hot on top and cold on the bottom). This allows air to be provided at the highest available temperature to the heated space from the top of the pebble bed. It also allows air to return from the bottom of the bed to the collector at essentially room temperature. This ensures maximum efficiency of solar heat collection and delivery.

The most efficient and least expensive heat storage device for use with a circulating air syst $\eta$ is a bin of clean pebbles between $3 / 4$ inch and $1 \frac{1}{2}$ inches in size. The storage volume is normally sized in accordance with the parameters illustrated. Increasing the storage above the range of 0.50 to 0.75 cuhic feet for every square foot of collector will have little or no effect on increasing heat obtained from the solar systcm.

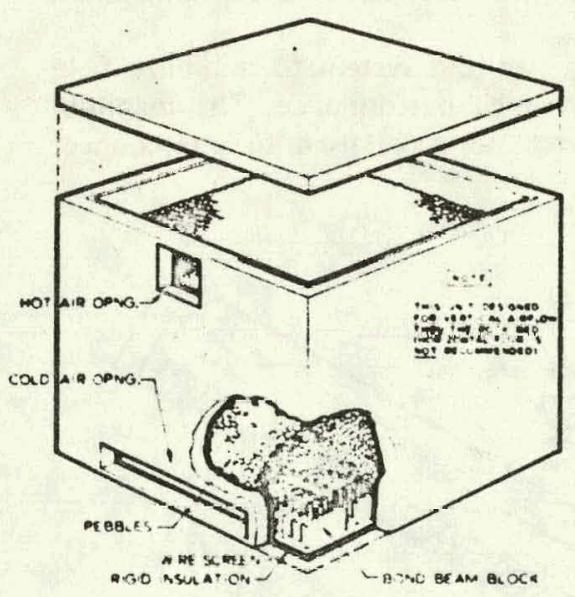

- EFEECT OF ROCK STOAMGE mass

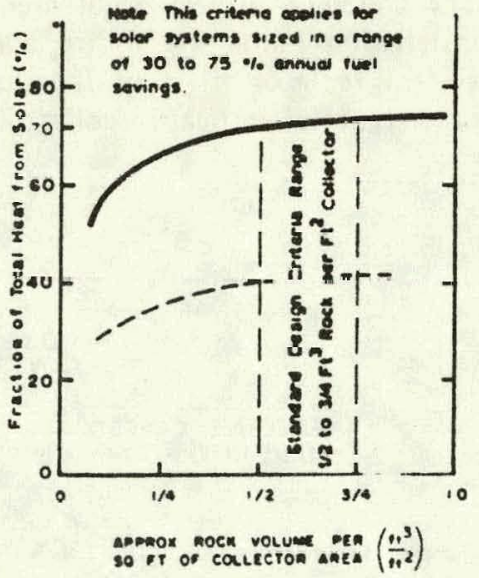




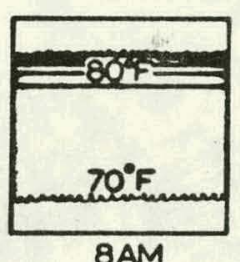

8AM

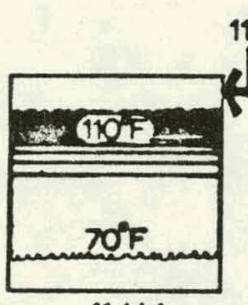

$11 \mathrm{AM}$

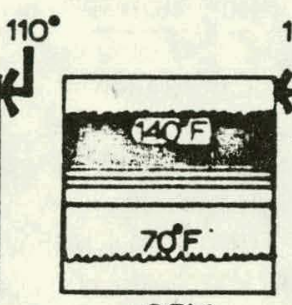

2PM

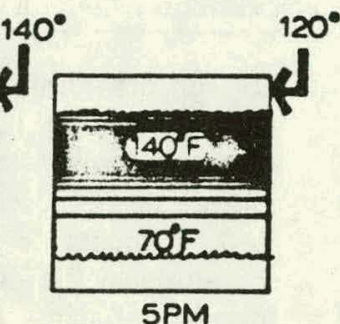

5PM

\section{Charge Cycle*}

A typical solar system during the winter starts in the morning after having used most of the stored solar energy for the nighttime heating requirement. The collector outlet temperatures (and temperatures into storage) typically peak during the middle of the day and are lower in the early morning and late afternoon. This results in stratified layers of heat such as $120^{\circ} \mathrm{F}$ to $140^{\circ} \mathrm{F}$ at the top, approximately $140^{\circ} \mathrm{F}$ near the middle, $100^{\circ} \mathrm{F}$ to $120^{\circ} \mathrm{F}$ near the bottom and $70^{\circ} \mathrm{F}$ at the bottom.

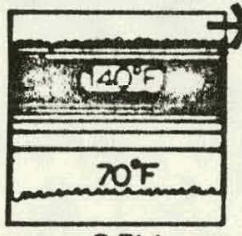

8PM

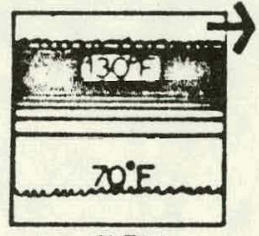

$11 \mathrm{PM}$

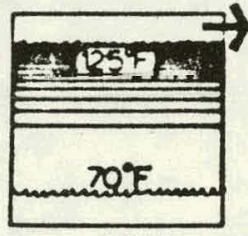

2 AM

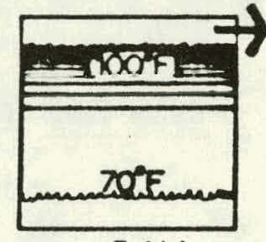

5 AM

\section{Discharge Cycle*}

Heat is extracted from the storage unit in reverse of the charge cycle.

The energy stored in the late afternoon is used first.

Energy stored at the highest temperatures during the middle of the day is used at night during the peak heating hours.

Energy stored from the early morning hours is used towards the end of the peak nighttime heating hours.

- Propagation of the temperature profile through the pebble bed during a typical charge-discharge cycle as measured in actual system operation at Colorado State University.

The length of time that the system can hedt from the solar storage unit will vary as a function of the amount of solar energy available and how cold it is outside. There can be times when there will be no heat in the storage unit (i.e. cold winter days when all of the solar energy collected during the day is entirely used up during the same day). 


\section{Solaron Air Handling Units}

Solaron provides a standard factory preassembled air handling unit, including a blower and field installed motor. A separate pair of motorized dampers is furnished for mounting in the duct system. The installer attaches ducts from the collectur, lieat storagc, and auxiliary heating system to the air handling unit. Certain systems may require additional motorized dampers.

The air handler can be mounted either vertically or horizontally. The motorized dampers are mounted at convenient positions in the ductwork between the collector and the air handler and between the air handler and the auxiliary heating system.

\section{Gravity-Operated Dampers}

A typical Solaron system will contain two gravity-operated dampers Incated on the return air side of the solar system. These dampers automatically open when air is blown through the ducts by the solar system. However, when the system is not operating these dampers will automatically close

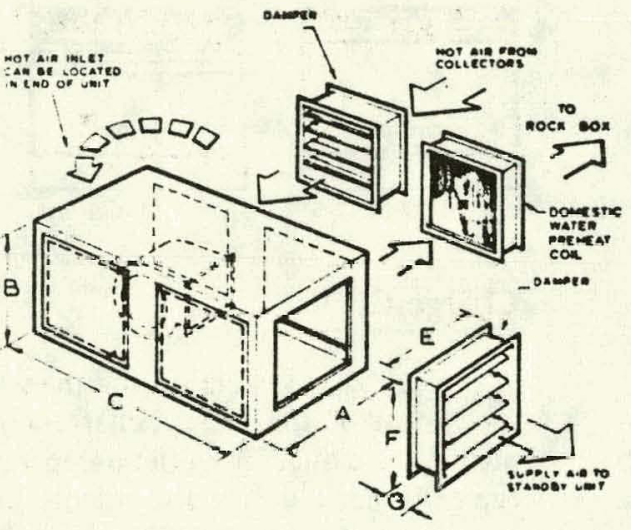
to prevent the cold night air from leaking down the ducts and into the heat storage unit.

\section{Domestic Water Preheater}

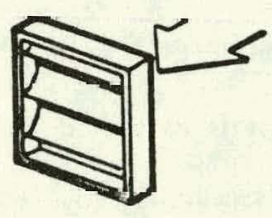

This is an option which may or may not be included in your system. The water preheater system contains an air-water heat exchanger coil, a small water circulating pump and an insulated storage stank. During all months of the year, hot air from the collector heats the water circulated by the pump through the heat exchanger coil. Warmed water is collected in the insulated storage tank, from which the regular water heater draws its supply. The preheater is replenished from the cold water line. A simple control turns the pump on when solar heated air is being delivered from the collector. While many systems have two domestic water tanks, certain system designs require only one. 


\section{System Controls}

As part of the complete heating system, Solaron furnishes an automatic control system, including the necessary sensors and switches. The controller acts to shift the system automatically from one mode of operation to another, as required. The control system turns on the blower for collector operation when the sun is providing enough energy for storage or use. It also controls the blower in the auxiliary heating unit when air circulation to the heated space is required. The controller shifts operation between heating the building space and storing heat during a sunny day, and later acts to circulate heated air through the storage intu the building at night. In addition, the control system turns on the auxiliary furnace when more heat is required than the solar collector or heat storage can furnish.

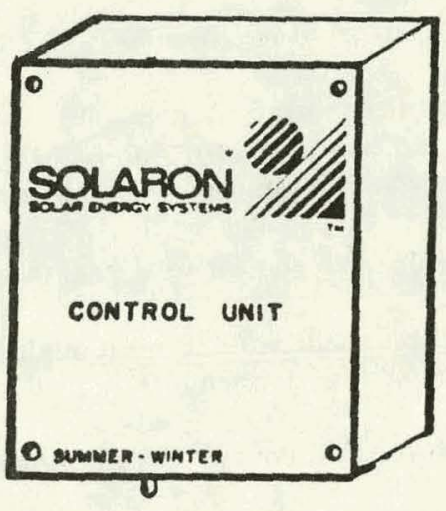

\section{Auxiliary Heating System}

Every solar heated building requires a full size, auxiliary heating unit which uses locally available fuel (electricity, gas, oil, wood, propane, etc.). Because Solaron's solar heating systems use air as the circulating heat transfer medium, they are easily integrated into conventional air distribution systems.

The auxiliary unit must be sized to furnish the entire building heating load on the coldest day of the year.

The auxiliary heating is furnished by gas, oil, or electric duct heaters or hydronic coils mounted in the conventional duct system. The automatic damper system in the Solaron air handler will automatically respond by directing air to the space or to storage, as required. Control interlock between the solar system and the conventional heating unit utilizes standard temperature control practices. 
The following information sets forth a detailed description of the control logic to operate a Solaron system. You should refer to the following system schematic and the legend to assist in understanding this section.

There are two models of Solaron controllers used in most Solaron systems:

1.) For use with conventional heating systems (which may include air conditioning).

2.) For use with most conventional heat pump auxiliary systems.

I. SOLAR ENERGY AVAILABLE. When a $40^{\circ} \mathrm{F}$ differential is achieved between sensors $T_{c o}$ (collector outlet) and $T_{c i}$ (collector inlet), the following events take place:

A. Storing Heat - no demand for space heating.

1. Differential thermostat in controller will energize control circuit to: open MD-1; turn on Solaron air handler blower; turn on hot water pump (optional); close MD-2.

B. First Stage Heating - demand for solar heat in space.

1. The controller circuit will: turn on auxiliary unit fan (auxiliary heat source is off); open MD-2.

C. Second Stage Heating - demand for additional heat (auxiliary).

1. The conventional space heating control circuit will bring on the auxiliary heat source (gas, electric, oil, etc.).

2. The heat pump control circuit will bring on the heat pump compressor and fully open MD-3. (Note: MD-2 closes on second stage for heat pump.)

D. Third Stage Heating (heat pump applications only).

1. A second thermostat will bring on electric resistance strip heating elements in auxiliary heating unit. (An outdoor temperature sensor may be used instead of a second thermostat.) 


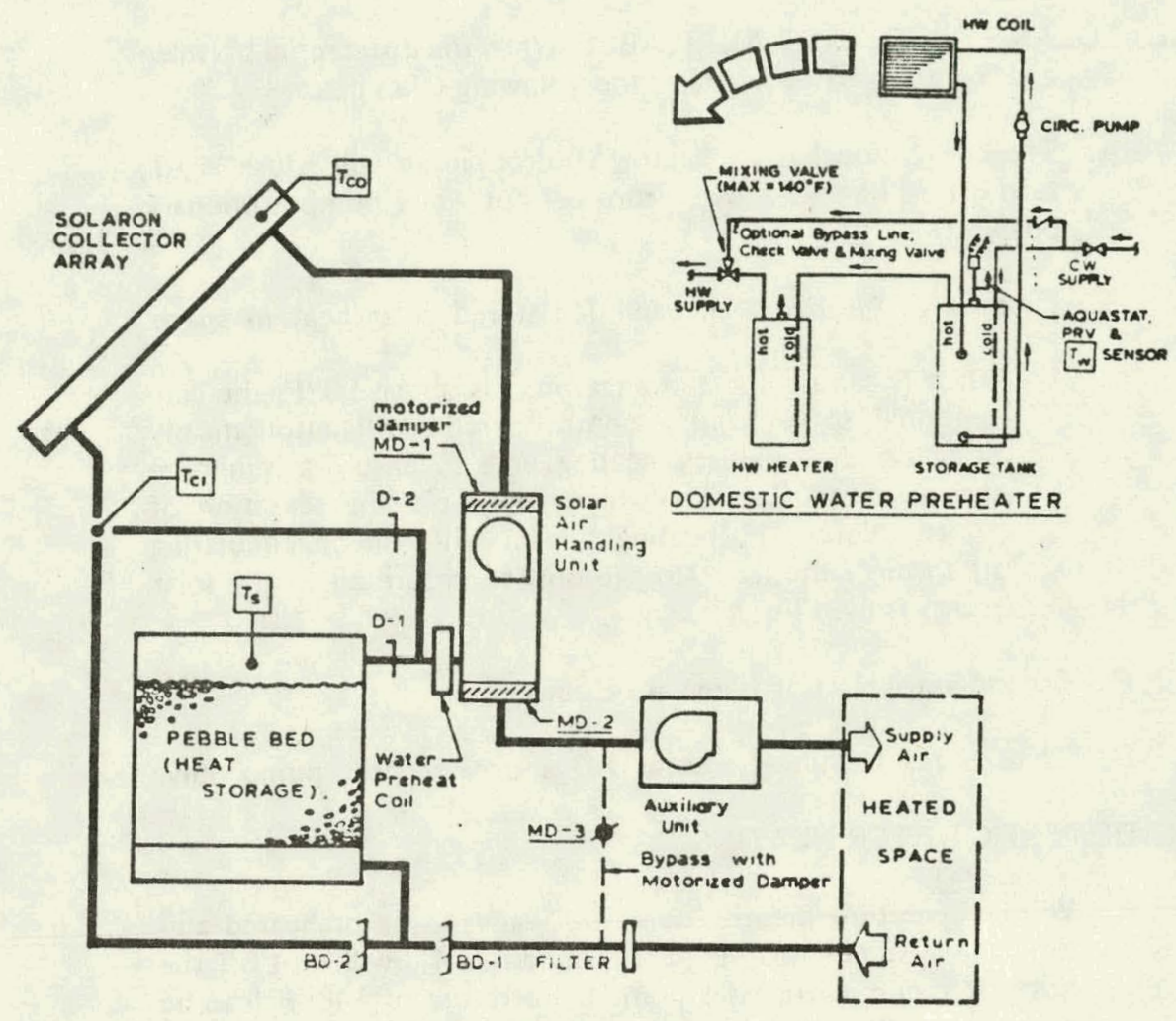

SYSTEM SCHEMATIC

\begin{tabular}{|c|c|c|c|c|c|c|c|c|c|}
\hline \multicolumn{10}{|c|}{ Sequence of Operation } \\
\hline MODE & MD-1 & MD.2 & BD.1 & BD-2 & D-1 & D-2 & $\mathrm{AHU}$ & \begin{tabular}{|l|}
$A U X$ \\
FAN \\
\end{tabular} & $\mathrm{MO}-3$ \\
\hline Heating from Collector & 0 & 0 & 0 & 0 & 0 & C & On & On & $\theta$ \\
\hline Heating from Storage & C & 0 & 0 & $\mathrm{C}$ & 0 & C & Off & On & $\theta$ \\
\hline Storing Heat & 0 & C & C & 0 & 0 & $\mathrm{c}$ & On & Off & 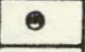 \\
\hline Water Heating (Summer) & 0 & C & C & $\mathrm{C}$ & C & 0 & On & Off & ? \\
\hline Air Conditioning and Water Heating & 0 & C & $\mathrm{C}$ & C & C & 0 & On & On & e \\
\hline $\mathrm{O}=$ Damper is Open & \multicolumn{3}{|c|}{$C=D$ amper is Closed } & \multicolumn{6}{|c|}{$0=$ See MD-3 design Criteria } \\
\hline
\end{tabular}

$\Delta T$ Differential thermostat

$T_{\text {ci }}$ Temperature sensor collector inlet

$T_{c o}$ Temperature sensor collector outlet

$T_{5} \quad$ Temperature sensor rock bin storage

$T_{W} \quad$ Temperature sensor water tank

$W_{1} \quad$ First stage of heat (solar)

$W_{2}$ Second stage of heat (auxiliary)

\section{MD-1 Motorized Dampers}

MD-2

MD-3

BD-1 Backdraft Dampers

BD-2

D-1 Manual Dampers

D-2

AHU Air Handling Unit 
II. SOLAR ENERGY NOT AVAILABLE. When the differential between $T_{c o}$ and $T_{c i}$ drops to $25^{\circ} \mathrm{F}$ or less the following takes place:

A. The conventional space heating control circuit will: close MD-1; turn off air handler blower; turn off hot water pump (optional); open MD-2.

B. First Stage Heating - demand for stored solar heat in space.

1. When $T_{s}$ sensor (heat storage box) is above $90^{\circ} \mathrm{F}$, the conventional space heating control circuit will automatically bring on the auxiliary heating unit to ensure a minimum supply air temperature which will avoid the sensation of drafts. (Note: The heating system will still be circulating air through the heat storage unit to ensure all of the solar energy is used.)

C. Second Stage Heating (same as I-C above).

D. Third Stage Heating (same as I-D above) - heat pump only.

III. DOMESTIC WATER HEATING

A. Winter operation permits domestic water to be preheated any time the system is storing heat. The sensor $T_{w}$ will shut off the hot water pump when set point temperature of $140^{\circ} \mathrm{F}$ (can be adjusted) in the domestic water storage tank is reached.

B. Summer operation permits the $T_{w}$ sensor, when satisfied, to shut down the hot water pump and Solaron air handler and close MD-1 until water temperature in the storage tank drops $15^{\circ} \mathrm{F}$ below set point of $T_{w}$.

\section{AIR CONDITIONING}

A. Solar available: System preheats domestic water, auxiliary system cools space as demand is dictated by thermostat and MD-3 opens fully.

B. Solar unavailable: Auxiliary system operates as in IV-A above and the solar air handler and domestic water pump are off. 


\section{HOW TO OPERATE YOUR SOLARON ${ }^{\circledR}$ SYSTEM}

The Solaron system is simple to operate. All you have to do is set the thermostat to the desired temperature. The automatic control system will do the rest. We recommend that to obtain the most benefit from your solar system you reduce the thermostat temperature setting to $65^{\circ} \mathrm{F}$ $\left(18^{\circ} \mathrm{C}\right)$ or less at night during the coldest period of the year when the storage will typically be depleted before morning. (Heat pump auxiliary units may be left at one temperature setting. Consult your heat pump supplier for setback. information.)

For the rest of the year, to minimize auxiliary energy usage, the thermostat should not be set back at night. If it is reduced, the usage of backup fuel may actually be increased. The system is designed to turn on the auxiliary system whien there is a two degree (or more) difference in the temperature of the heat space and the thermostat setting. Accordingly, when you increase the thermostat setting in the morning, the auxiliary heating system could be turned on even though there may still be suffi. cient heat (solar) in storage.

\section{Winter - Summer Operation}

Many solar systems have two operating cycles. The winter cycle is for heating your home and preheating the domestic hot water (if you selected this option). The summer cycle is only for preheating the domestic hot water. The system controller has a switch which is visible from the outside. You should move this switch to the desired operating cycle. The system controller is typically located in the mechanical room, near the air-moving equipment. YOU DO NOT HAVE TO REMOVE THE COVER OF THE SYSTEM CONTROLLER TO MAKE THIS ADJUSTMENT.

A typical system may also have one or more dampers which must be changed at the same time. See schematics on pages 13, 4, 5 and 6 for the location of these dampers D-1 and D.2. These dampers are generally manually operated. These dampers are not supplied by Solaron so you should have the installer explain how to operate the dampers he selected for your system. IF THE DAMPER IS SET IMPROPERLY YOU MAY GET NO STORED HEAT IN THE WINTER WHEN YOU NEED IT OR YOU MAY STORE HEAT IN THE SUMMER WHEN YOU DO NOT NEED IT. Some locations may require heat to be stored in the summer due to night heating needs. 


\section{Optional System Monitor}

Your system may have an optional "System Monitor" which would typically be installed near the thermostat. Six operations are monitored and will indicate which functions of the system are operating. Typically the monitor will show the simultaneous operation of more than one function.

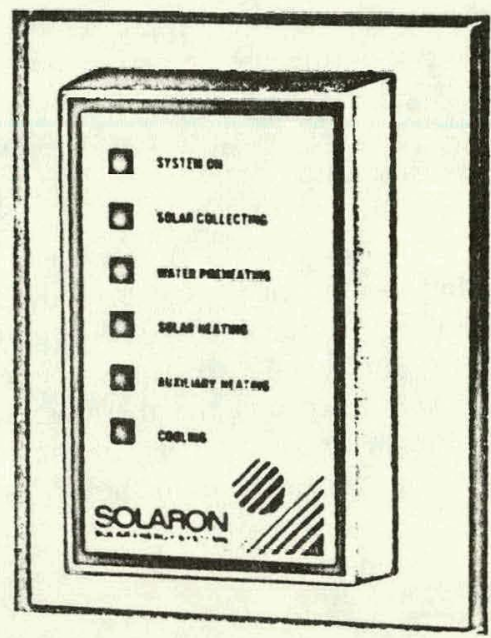

A light by these operations indicates the following functions.

System On:

System is ready to operate. If this light is not on then check circuit breaker or fuse box. If the light still is not on then call serviceman.

Solar Collecting: Power is being supplied to the solar air handler, the blower motor is operating and air is circulating through the collector.

Water Preheating: Power is being supplied to the water pump and the domestic hot water preheat is operating. This operation will function only if you selected this option.

Solar Heating: Solar heat is being supplied to the house. If solar collection light is also on then heat is being supplied directly by the collector; otherwise, heat is being supplied from storage. If auxiliary heating light is also on then the solar system is supplying part of heat requirement.

Auxiliary Heating: Auxiliary heating system is operating.

Cooling: This operates only if the house has conventional air conditioning. 


\section{ROUTINE MAINTENANCE}

The Solaron system requires only minimal upkeep for economical and long-lasting operation. We recommend that a qualified serviceman check the operation of the system twice a year. The system installer will either perform this service for you or will recommend a serviceman.

BE SURE TO DISCONNECT ELECTRICITY BEFORE SERVICING ANY ELECTRICAL COMPONENTS (controller, air handler, dampers, etc.).

The minimum maintenance requirements to be done are described below:

\section{Sularon Air Handler Model AUO400 AND AU0500}

Blower Motor

Blower Bearings

V-Belt

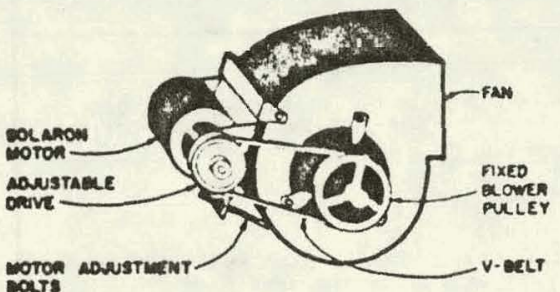

Visually check motor to confirm which type you have. DO NOT OVER-OIL.

Type 1 - Permanently sealed bearings - no oil required.

Type 2 - Motor with oil cups - oil twice a year (\#20 S.A.E. non-detergent oil).

Permanently sealed - no oil required.

Check wear and tension, replace if necessary.

Solaron Motorized Dampers

Damper Motors

Damper Linkage

Water Pump

Filters
Oil twice a year (\#10 S.A.E. non-detergent oil, similar to \#465 Anderol or Goodlight \#10 oil). DO NOT OVER-OIL.

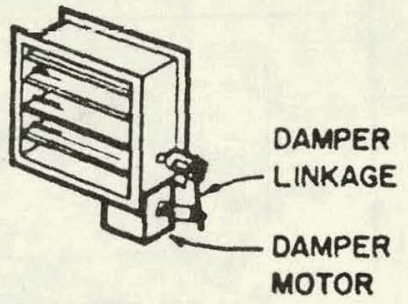

Check play and tension of all push rods and arms. Check damper closing for tight seal. Readjust if needed. Oil fsame as damper motor above).

The Grundfos circulation pump requires no oiling since it is water lubricated during normal operation. Your system will have a water pump only if the domestic water preheat option is selected.

These should be changed twice yearly or more often if conditions warrant. It is important that filters be clean if the system is to operate efficiently. New system owners should change filters after the first four weeks of operation: 


\section{STEPS TO FOLLOW TO OBTAIN MAXIMUM PERFORMANCE FROM YOUR SOLARON ${ }^{\circledR}$ SYSTEM}

Estimates of syștem performance are typically based on average weather bureau data accumulated over many years. Yearly variations are to be expected because of changes such as solar radiation available, temperatures, wind conditions and living habits.

The amount of heat supplied by the solar system will vary by month. For example, a system designed to supply 60 percent of the ANNUAL heating requirement may supply only 25 percent in the coldest month of the year and virtually all the heating requirements in the spring, summer and fall. If a system is supplying only 25 percent of the heating requirement for a month, then most of the heat produced by the solar collector that month will be supplied directly to the heated space during the day and very little, if any, heat will be retained in storage for use at night.

CRTERTA FOR SELECTION OF THE ANNUAL FUEL SAVINGS PERCENTAGE

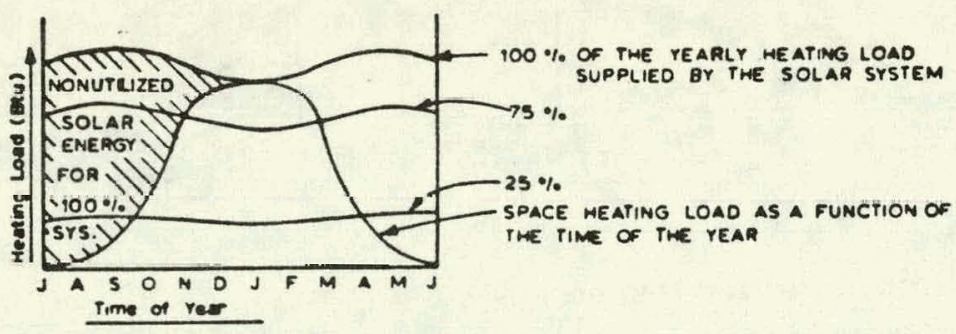

BULDING SPACE

THE LOAD VARES WITH THE TIME OF THE VEAQ TUE SOLAR SYSTEM SHOULD MORMALLY BE SIZED TO RAOVIDE $25 \%$ TO $75 \%$ OF THE YEARLY MEATINO LOAD.

NOTE THE $100 \%$ SYSTEM HAS A LAREE AMOUNT OF NONUTILIZEO ENERGY AND IS IMPRACTICAL \& UNECONOMICAL. 
To improve the effectiveness of your solar system you should do the following:

- Insulate your house. Consult local insulation suppliers for exact $R$ value recommended for your area.

- Use double pane glass or storm windows.

- Remember that many fireplaces waste heat when they are in use.

- Keep fireplace dampers closed when not in use.

- Run exhaust $f \sim n$ for minimum time.

- Keep windows and doors closed during heating season.

- Set thermostat at maximum of $70^{\circ} \mathrm{F}\left(21^{\circ} \mathrm{C}\right)$ during day and maximum of $65^{\circ} \mathrm{F}\left(18^{\circ} \mathrm{C}\right)$ at night only during the coldest period of the year. See section on "How to Operate Your Solaron System" for a description of the problems of improper night setback.

- Caulk your house to minimize air leaks.

- Minimize usage of electrical, fuel oil and/or gas operated appliances. What may appear as fuel usage may also be increased usage of other appliances.

- Insulate the preheat water tank and hot water tank, if tanks are not supplied with adequate insulation.

- Insulate hot water lines.

- Note that the collectors are free from shading.

You should contact your serviceman only after concluding that you have done everything possible to conserve energy. 


\title{
IF YOUR SOLARON SYSTEM DOES NOT WORK
}

To obtain assistance you should:

- First, contact the system installer. If you do not know the company's name then call your builder.

- If your system installer should not be readily available, then contact any installer of Solaron equipment (see telephone Yellow Pages).

- If you need further assistance, contact the nearest Solaron distributor (see telephone Yellow Pages).

- Should all efforts to obtain local assistance not be successful, then contact:

\author{
Solaron Corporation \\ 300 Galleria Tower \\ 720 So. Colorado Boulevard \\ Denver, Colorado 80222 \\ Telephone (303) 759-0101
}

Due to Solaron $\$$ s continuing policy of product improvement, products and specifications may change without notice. 
SYSTEM DRAW INGS 


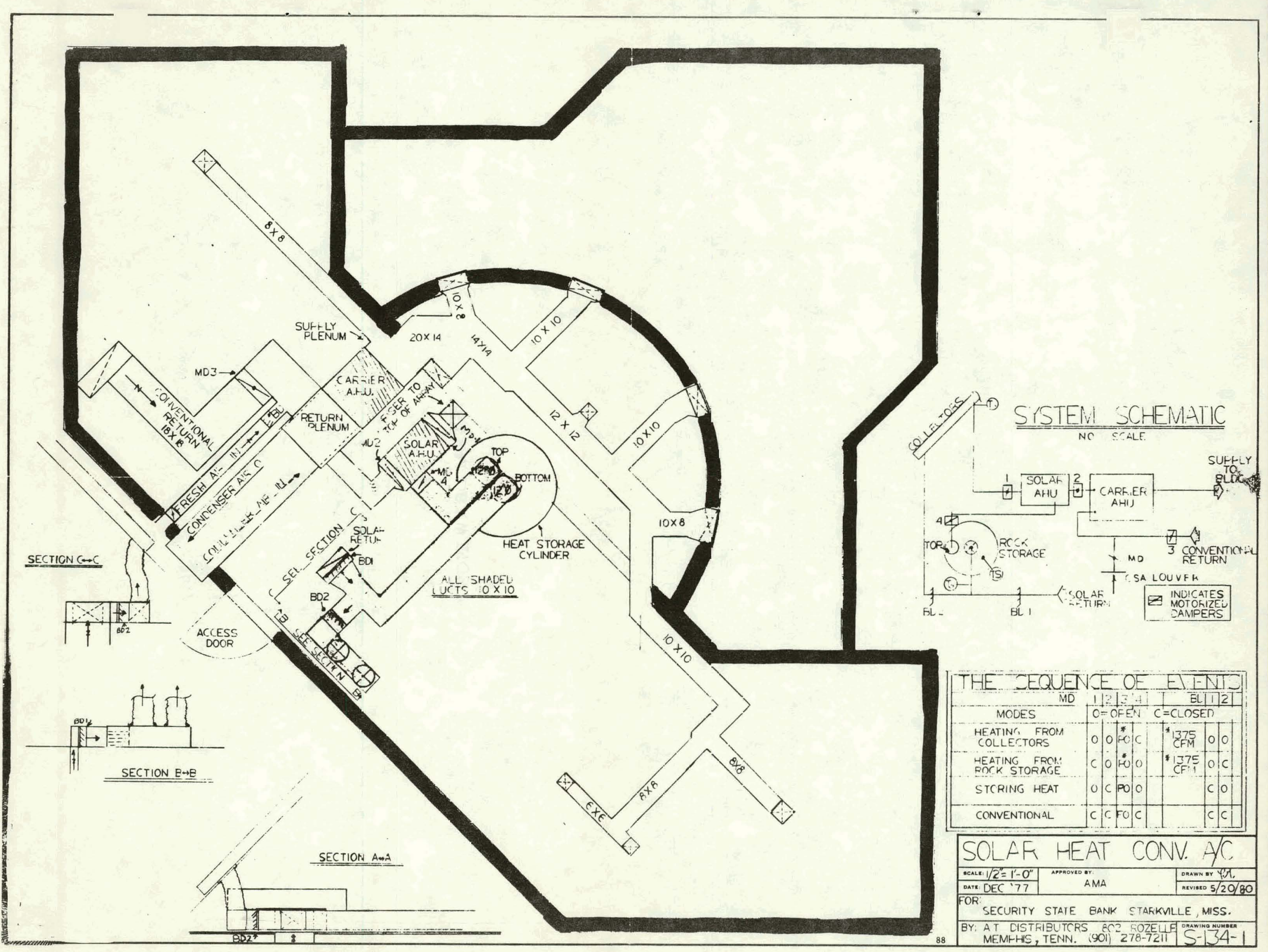




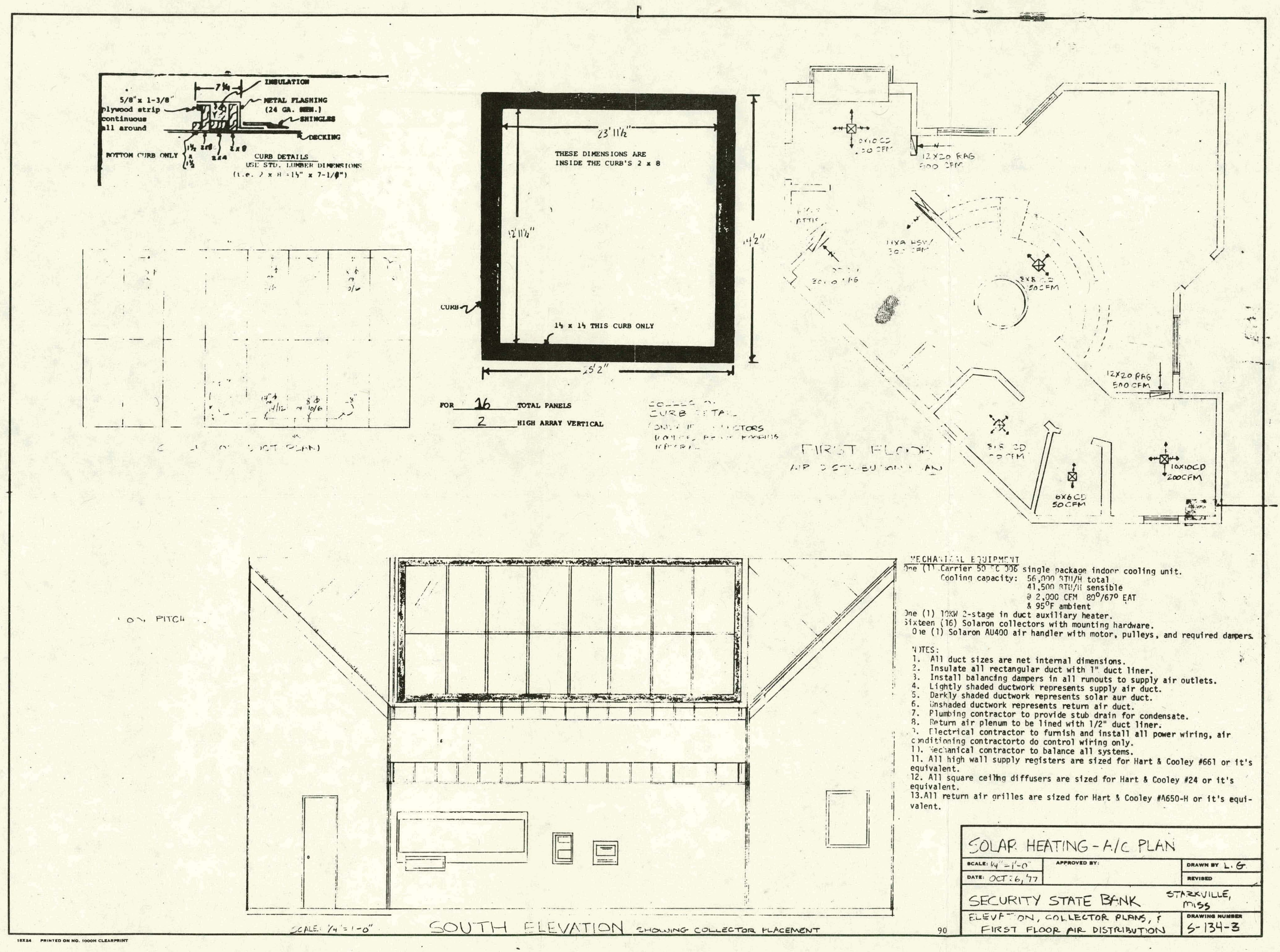

